\title{
GEOTHERMAL PROGRESS MONITOR, REPORT NO. $\boldsymbol{g}_{\text {, }}$ JUNE 1985 A decrke 0
}

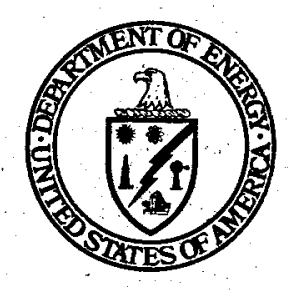

\section{U.S. Department of Energy}

Assistant Secretary for Conservation and Renewable Energy Geothermal Technology Division Washington, D.C. 20585

\author{
Prepared in Cooperation with the \\ Interagency Geothermal Coordinating Council \\ with the Assistance of \\ The Meridian Corporation, Falls Church, Virginia
}




\section{DISCLAIMER}

This report was prepared as an account of work sponsored by an agency of the United States Government. Neither the United States Government nor any agency Thereof, nor any of their employees, makes any warranty, express or implied, or assumes any legal liability or responsibility for the accuracy, completeness, or usefulness of any information, apparatus, product, or process disclosed, or represents that its use would not infringe privately owned rights. Reference herein to any specific commercial product, process, or service by trade name, trademark, manufacturer, or otherwise does not necessarily constitute or imply its endorsement, recommendation, or favoring by the United States Government or any agency thereof. The views and opinions of authors expressed herein do not necessarily state or reflect those of the United States Government or any agency thereof. 


\section{DISCLAIMER}

Portions of this document may be illegible in electronic image products. Images are produced from the best available original document. 
Introduction..................................................1

The Federal Beat ......................................... 3

10 Years Later in Geothermal Development - 1974-1984...........................3

Progress in Experimental

Geothermal Technologies..................36

Geothermal R\&D

-The Present and Future

10 Years Later in Geothermal Leasing 1974-1984 4 _.........................................44

The Industry Scene.0.0.0.0.0.0...................49

Financing ..............................................5 53

Development Status...............................55

Leasing and Drilling.............................67

State and Local................................... 75

International............................................83

Technology Transfer ............................89

Directory....................................................... 99 
The Geothermal Progress Monitor (GPM) has been published by the Geothermal Technology Division of the U.S. Department of Energy since January 1980. As 1ts title implies, Its purpose is to monitor geothermal development in this country and abroad in order to identify and quantify trends in the use of geothermal energy. The GPM is thus not intended to be a "news" publication, although the Division would like for $1 t$ to serve that purpose as well for those in the geothermal community who do not have full. access to the publications and data bases avallable to the GPM. In addition, it provides current directories of cognizant government of 1 cials - federal and state - to facilitate access to approprlate contacts.

The GPM has of ten featured a theme spectal to the 1ssue. This Issue - No. 9-focuses on 10 years of progress in:

- geothermal research and deve1opment

- geothermal leasing

- geothermal resource assessment.

The chronicle of the 10 years of progress by both industry and government is essentialiy a dedication of this issue to the emergence of a hot water geothermal power industry. This development by industry is the realization of the near-term geothermal goal of DOE and 1ts predecessor agenctes.

Readers famlliar with past issues of the GPM will note a new format for this one. It is designed to provide Information of Interest to all sectors of the geothermal community. It is hoped that, by maintalning the format through future 1ssues, familiarity with it will assist the reader in quickly locating the subject areas of greatest interest.

Within each issue however, the degree of emphasis on a given subject area or areas will vary. For example, THE FEDERAL BEAT in this issue contains the detalled story of progress and description of the current DOE geothermal program and its future direction. In other issues, this section may consist only of news Items on federal activities.

This Issue also covers other events of significance in geothermal development from late 1983 through the end of 1984. Issue No. 10 , coverIng developments during 1985, is in preparation.

The Geothermal Technology Division welcomes any comments or suggestions for future GPM issues and so1icits news of geothermal activities. 


\section{KNOWN GEOTHERMAL RESOURCE AREAS}

(KGRA's) WHERE HOT WATER PLANTS ARE IN OPERATION, UNDER CONSTRUCTION, OR PLANNED

(as of December 1984)

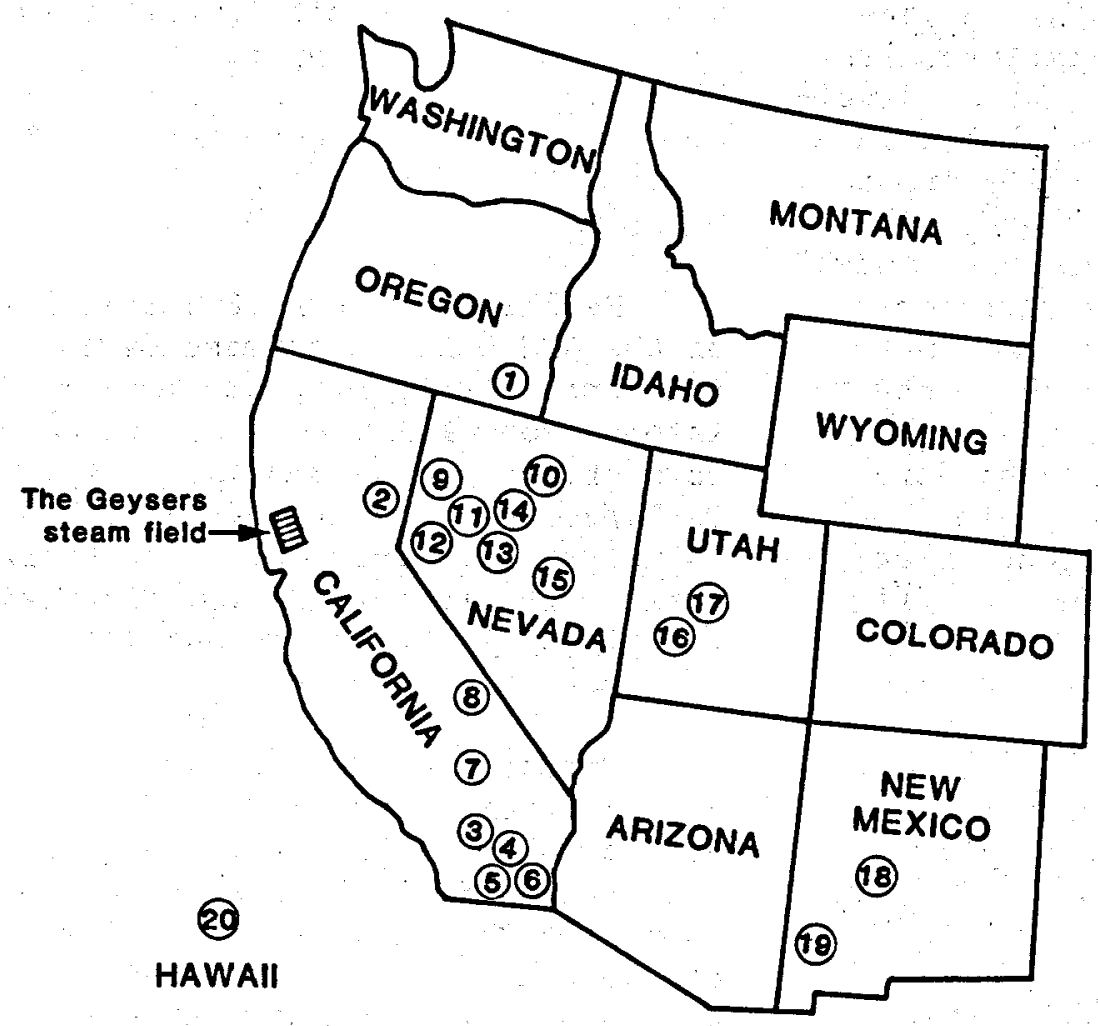

1- Lakeview, OR

2- Wendel-Amedee, CA

3- Salton Sea, CA

4- Brawley, CA

5- Heber, CA

6- East Mesa, CA

7- Coso Hot Springs, CA

8- Mono-Long Valley, CA

9- Brady Hazen, NV

10- Beowawe, NV
11- Salt Wells Basin, NV (declassified)

12- Steamboat Springs, NV

13- Wabuska, NV

14- Dixie Valley, NV

15- Darrough Hot Springs, NV

16- Roosevelt Hot Springs, UT

17- Cove Fort Sulphurdale, UT

18- Gila Hot Springs, NM

19- Lightning Dock, NM

20-Puna, HI (not KGRA) 
1974 was a banner year for geothermal energy in the United States. Three events of major significance took place that in 1984 provided the baseline for measuring progress in the development of this resource.

The Geothermal Energy Research, Development, and Demonstration Act was enacted by the U.S. Congress on September 3, 1974, establishing a formal federal geothermal research and development program. In August of that year, the first competitive geothermal leases were issued pursuant to the Geothermal steam Act of 1970. And, in the same year, the U.S. Geological Survey Initiated the first comprehensive assessment of the geothermal resources of the United States.

These actions did not result in an overnight success story. To the contrary, progress has been slow over the 10 years in both technology development and leasing of the federal lands available for geothermal explo1tation, the pace retarded by many direct and Indirect influences. In addition, a large portion of the Nation's resource base has yet to be identified. Nevertheless, In 1984 real progress arrived in geothermal development, a product of the efforts of Industry and government. Thus, THE FEDERAL BEAT for this issue $1 \mathrm{~s}$ the 10-year story of achievements and setbacks, the current status, and the direction for tomorrow.

GEOTHERMAL RESEARCH, DEVELOPMENT, AND DEMONSTRATION ACT

In 1974, memories of the long lines at gasoline service stations, created by the 1973 embargo on sh1pments of foreign o11, were very fresh In the minds of the American public. Prices of energy in all forms were soaring. As a result, public pressure for federal support of the development of alternative forms of energy grew to a ground swell. It was in this climate that the Geothermal RD\&D Act was passed.

The Atomic Energy Commission had been given an earller mandate from Congress to conduct geothermal research and development, as had the National Sclence Foundation. While. some of the major geothermal programs st1ll ongoing today had thelr origins within those agencies, the RD\&D ACt made the first "national commltment...to dedicate the necessary financial resources and enlist the cooperation of the private and public sectors in developing geothermal resources..."

Responsibility for coordinating and managing the federal geothermal. R\&D program was placed in a Geothermal Energy Coordination and Management Project, known today as the Interagency Geothermal Coordinating Council. However, when the Energy Research and Development Administration (ERDA) was created in January 1975 , It was given responsibility for the federal R\&D program. The responsibility was subsequently passed to. the Department of Energy when $1 t$ was created in 1977.

\section{THE GEOTHERMAL "INDUSTRY" IN 1974}

If the term "Industry" is defined here as a group of for-profit enterprises, the geothermal industry in 1974 consisted of: 
- the power generating plants at The Geysers and the wellfleld providing steam

- the Bolse, Idaho, district heating system

- a few small commercial greenhouses

- their suppliers of engineerIng services, equipment, and materials.

The only other uses of record were other direct heat applications by both the public and private sectors.

The generating capacity at The Geysers was 396 MWe. Ten Pacific Gas and Electric Co. (PG\&E) units were on-line, and the operation was second in size only to the geothermal installations at Larderello, Italy. S1x modern 53. MWe plants accounted for the bulk of the capacity, a glant step from the wooden shed-type structure of the first 11 MWe plant built In 1960.

Contrary to the ascendancy of The Geysers operations, the oldest geothermal district heating system in this country was in decline. At its peak, the Warm Springs Avenue system in Bolse, Idaho, served 400 homes and business establishments. By 1974, the distribution system, built in 1890 , had become antiquated, badly in need of a major capital outlay for renovation, and only marginally profitable for the Bolse Water System. A citizens group, Independently Incorporated and privately financed, had taken over the operation to serve the remaining 170 customers.

By 1974, most of the eastern portion of the City of Klamath Falls, Oregon, was heated by hot water in a unique application that is, to a large extent, a one-well-one-structure approach, with approximately 400 wells supplying about 500 structures

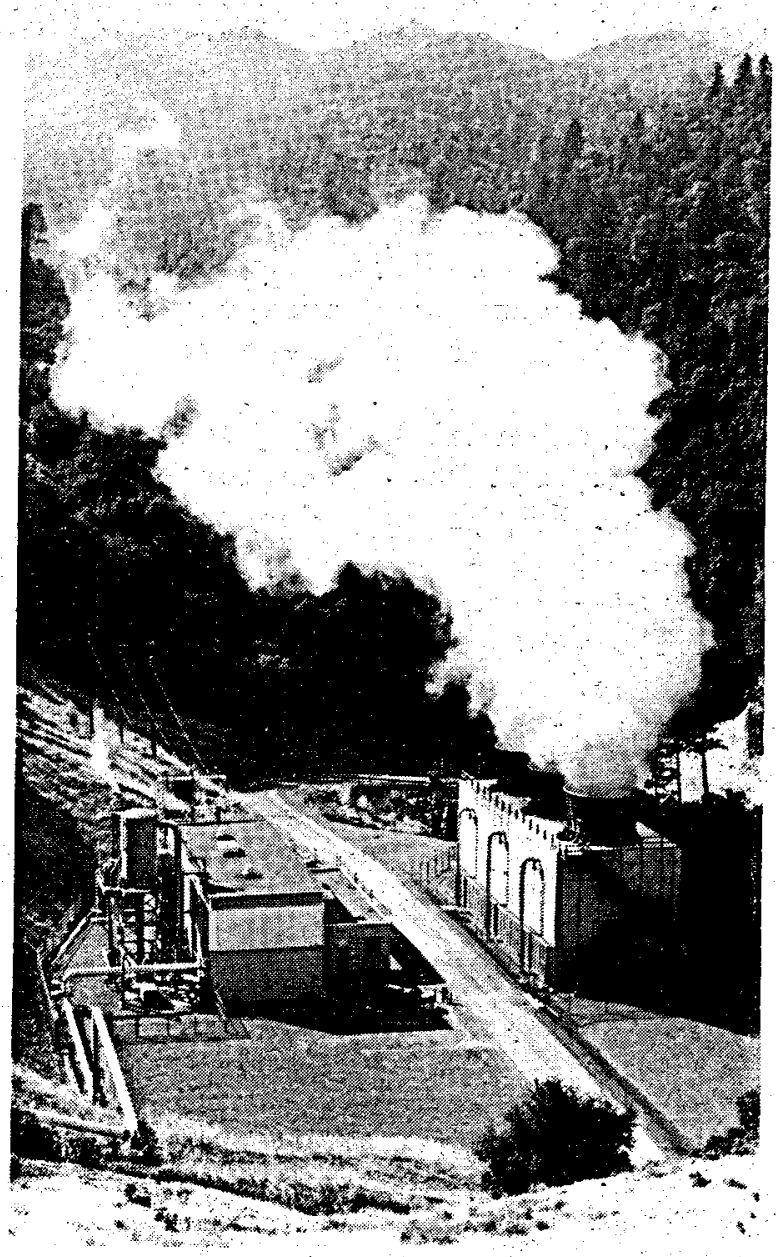

Pacific Gas and Electric Unit No. 1 at The Geysers, the first commerclal power plant in the U.S.

Courtesy of Pacific Gas and Electric Company.

in 1974. Since at least the turn of the century, users had installed their own wells, typically using a downhole heat exchanger to heat city water circulating in a closed system. Space heat users in 1974 included residences, city schools, and the Oregon Institute of Technology. Other users Included milk pasteurization and commercial laundering.

At this time, the Bureau of Reclamation was operating a demonstration of desalting geothermal brines at East Mesa in the Imperial Valley to study the feasibility of augmenting the water supply to the Colorado River from sources within the Basin. It was determined, however, that all 
desalting processes tried were far too expensive, including a multistage flash desalting plant combined with $a$ binary power plant for the concurrent production of water and power.

Perhaps the best known geothermal greenhouses in the mid-1970's were those near Susanville, California, used for growing tomatoes by the solilless hydroponic method. The hot water from a surface hot spring - no wells were drilled -- was used to heat the greenhouses and, with the addition of nutrients, to irrigate the plants which were grown in gravel. By mid-1974, six greenhouses had been completed in this facility.

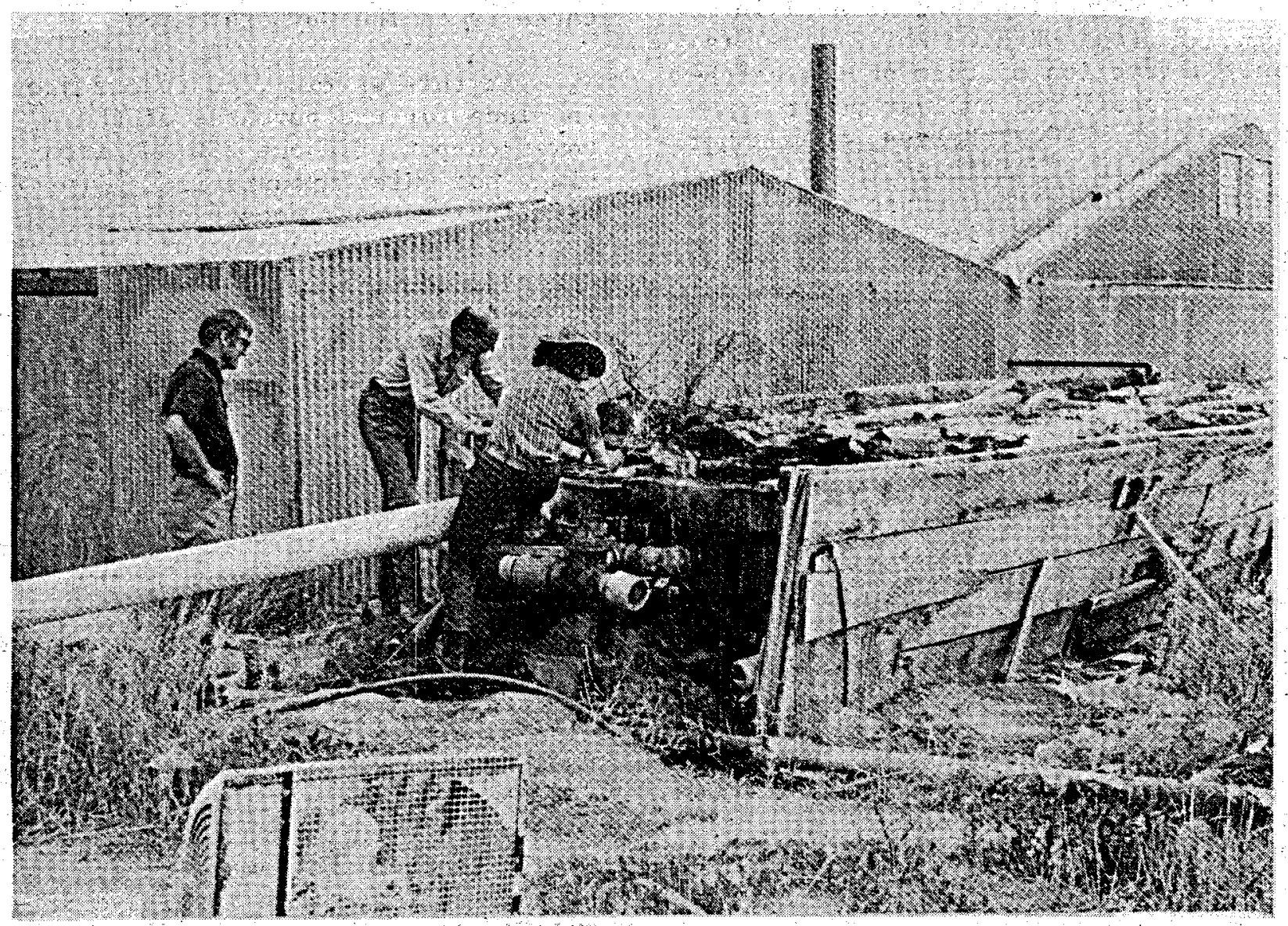

1974 geothermal greenhouse in Raft River Valley, Idaho, The heat exchanger (shown here) was a tub of hot geothermal water (180 degrees Fahrenhelt). 


\section{THE GEOTHERMAL INDUSTRY} IN 1984

Despite several factors working against 1t, a geothermal industry is emerging today beyond the realm of The Geysers. The hot water resource has reached commercial status notwithstanding: 1) reduced power plant construction of all types; 2) low competing fuel prices; 3 ) very high geothermal drilling costs; and 4) relatively new power conversion technologies.

The total megawatt capacity of all the hot water plants in operation, under construction, and planned in the U.S. (see DEVELOPMENT STATUS) is only a fraction of that of the established fossil and nuclear power industries. Nevertheless, the number of plants 18 significant in today's market of lower than expected power demand, and their size is a plus factor In satisfying today's smaller Increments of growth. They will also provide the experience needed to attract others to the use of this resource.

Development also continues at The Geysers, by newcomers as well as the established steam producers and utility. This area embraces the greatest amount of geothermal power generation capacity of any site in the world despite some large developments abroad.

A number of new direct uses of geothermal heat have been Installed, beyond a group of such projects partially funded by DOE as field experiments.

\section{HYDROTHERMAL POWER GENERATION}

As Indicated by the above discussion, the geothermal industry today is confined to the use of HYDROTHERMAL fluids, and, except for a small, pllot-scale geothermal generating unit in Hawail and another operated briefIy in Idaho, California was the scene of all U.S. geothermal power development unt11 1984. Today, there are plants, some of them sma11-scale units, operating in Nevada, New Mexico, Oregon, and Utah. Additional geothermal capacity is planned for all four states.

California will remain the leader for the foreseeable future, however. This is true even when the capacities of plants under construction or planned to utilize 1iquiddominated resources are tabulated alone, uninflated by the large capacity at The Geysers.

At this writing, contracts are in place for the purchase of the power output of about 250 MWe from nine "hot water" plants in California existing or under construction. Approximately 80 percent of this capacity is in Imperial Valley. Expansion is planned for several of the plants - e.g., the capacity of the ChIna Lake Naval Weapons Center facility is to be increased in incre ments from the initial 25 MWe currently under construction.

In addition to the "boost" given to geothermal development by the new plant construction, considerable encouragement for the future of this resource is of fered by the performance of the existing hot water demonstration plants. While both the Magma Power Co. 10 MWe binary plant at East Mesa and the Union 011 Co. of Callfornia/Southern California Edison flash plant of the same size at Brawley suffered some initial difficulties after they came on-1ine in 1980 , their performance is now rel1able and consistent. Similarly, although all problems are not completely solved, the Union/SCE 10 MWe plant near the Salton Sea, which began operation in 1982 , is performIng we11. In addition, the Utah 
Power and Light Co. was sufficiently impressed with the efficiency of a small ( $1.6 \mathrm{MWe}$ ) biphase generating unit subjected to long-term performance tests that it is using this total flow technology to increase the output of both its 20 MWe plant near Milford and the new 14 MWe plant under construction. More information on the individual hot water plants under construction and planned is found in THE INDUSTRY SCENE and DEVELOPMENT STATUS.

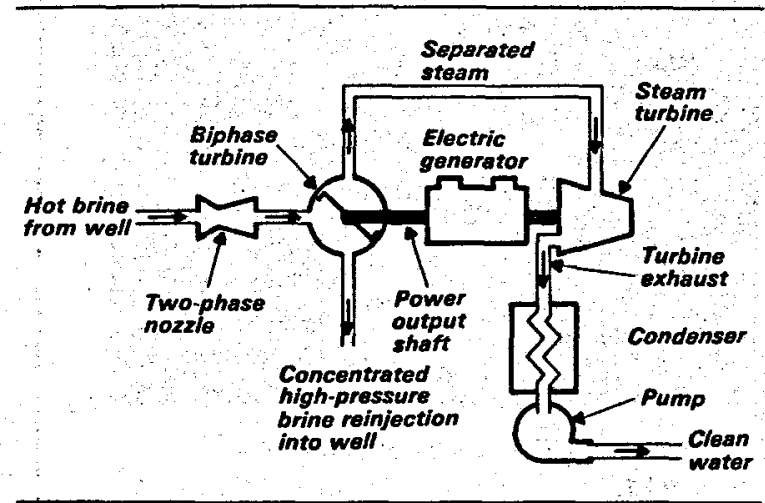

The Biphase rotary-separator Iurbine coriverta kInetlc and pressure energy in the geothermal brine to shaft power. It is a valuable adjunct to llash steam tutbine Installatione.

The scene at The Geysers has changed markedly since 1974 . PG\&E's generating capaclty has increased from less than 400 MWe to over 1100 MWe, and the number of plants has grown from 10 to 17. An additional 262 MWe is generated by newcomers to The Geysers. Owners of these plants include the Northern Californta Power Agency (NCPA), Sacramento Munic1pal Utility District (SMUD), and Santa Fe International. The Santa Fe plant, built by Occidental Geothermal, is the first at The Geysers to be owned by a non-utility field developer.

Occidental was only one of several new field developers operating in the area. Once the sole domain of the Union/Magma/Thermal consortium that originally supplied all of
PG\&E's steam, steam suppliers now include Thermogenics, Inc., Phillips Petroleum Co., and Grace Geothermal. In addition, MCR Geothermal and Geothermal Resources International are drilling in preparation to serve naw plants.

The plants scheduled to come on IIne in 1985 include the Bottle Rock plant of the California Department of Water Resources, the second NCPA plant, and PG\&E's Units 16 and 20. Additional plants planned for The Geysers are identified in DEVELOPMENT STATUS.

\section{DIRECT USE}

The annual thermal energy use of a total of over 260 geothermal direct use projects, either on-line or under construction, has been estimated to be over 1861 billion Btu's. A recent survey by the Meridian Corporation found that of the total annual direct utilization, space and water conditioning projects ( 473 billion Btu) account for approximately 25 percent; district heating projects $(426$ bilIIon Btu) are estimated to account for 23 percent; commerclal fish farms ( 396 billion Btu) comprise 21 percent; commercial greenhouses ( 328 billion Btu) contributed 18 percent; while projects involving small resorts ( 120 bililon $B t u$ ) and industrial process heat ( 118 billion Btu) combine to make up the remainder. All but one of the identified active projects are located In states west of the Mississippl River, with the bulk of the geothermal energy direct heat utilization occurring in California, Idaho, Oregon, Nevada, and New Mexico.

Under the narrow definition of a "district heating system" used in the survey - a public utility system - there are 11 such systems in operation in the U.S. and six under construction. Other multiple-structure geothermal heating systems, such 


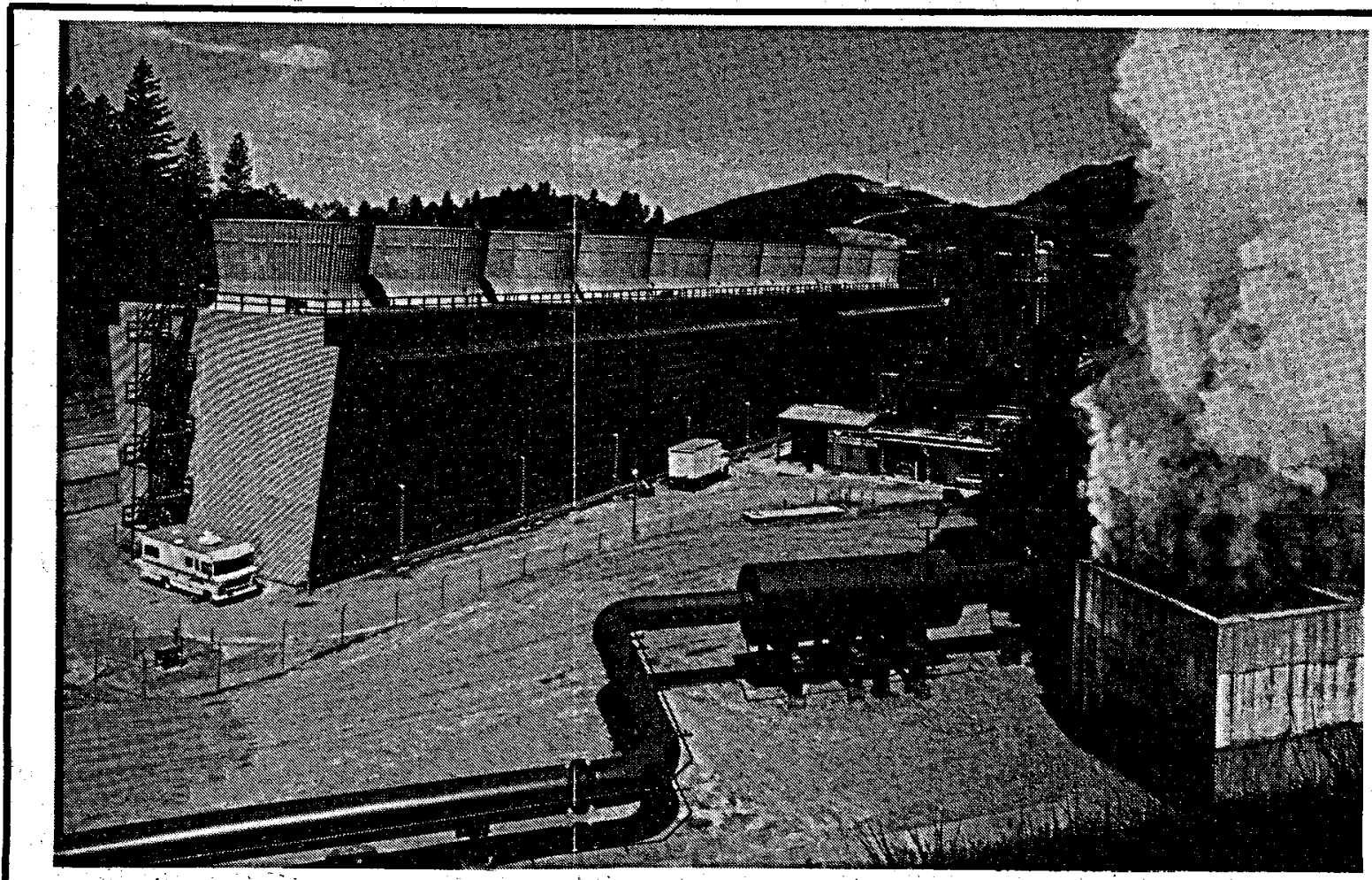

At 135 MWe, this Pacitlc Gas and Electrlc plant at The Geysers is the largest geothermal power plant in the world.

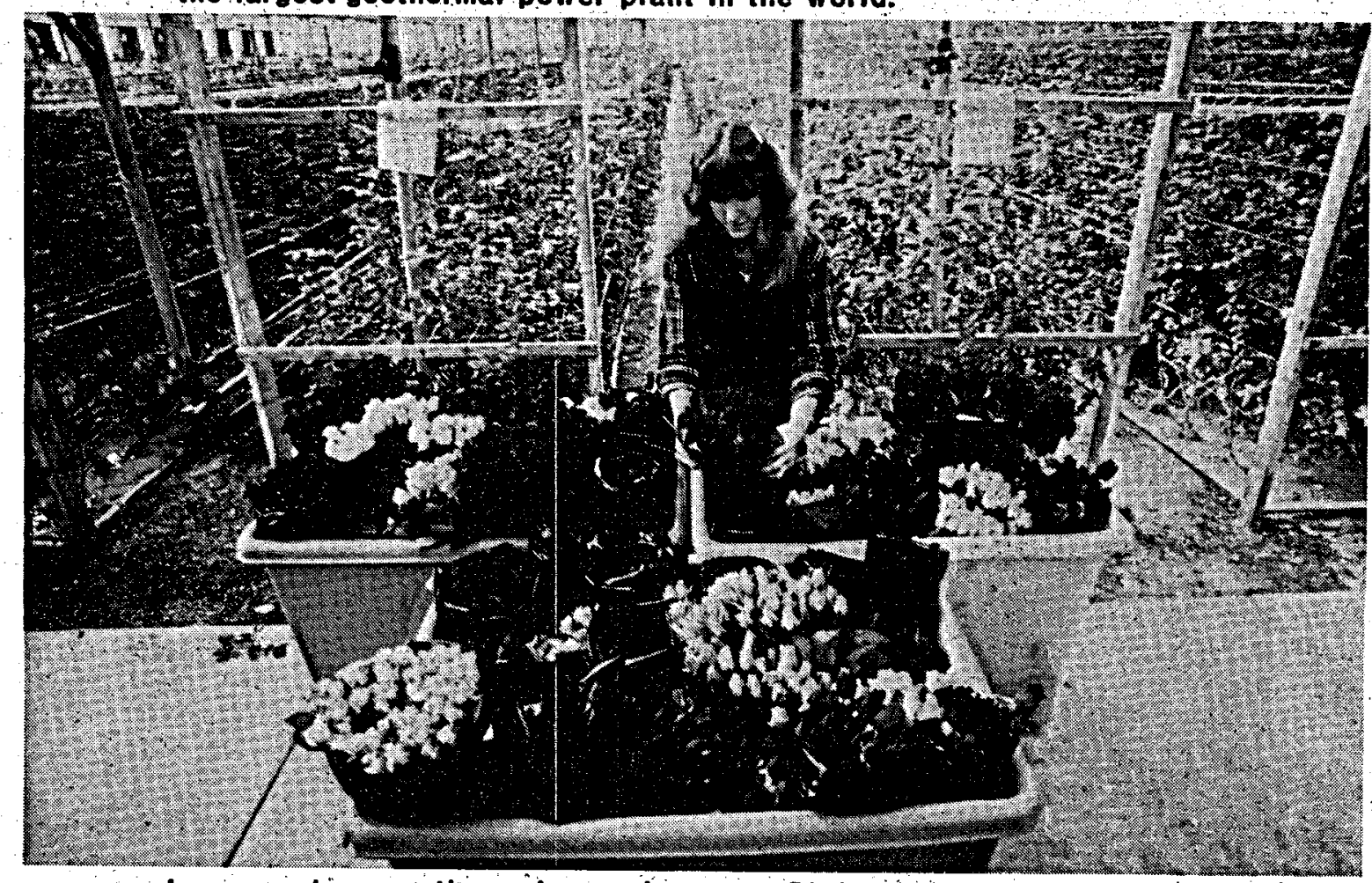

Large modern geothermal greenhouse at Bluffdale, Utah. The entire geothermal system, including production and Injection wells, cost less than one year's natural gas requirement. Operation and maintenance costs are minimal. Courtesy of Utah Roses. 
as those of college campuses, other Institutions, and large resort complexes, were counted In the "space and water conditioning projects," the largest of the utilization categories.

of the nine aquaculture projects identifled, three large fish farms in Buhl, Idaho; Wabuska, Nevada; and Mecca, Callfornia, account for nearly 80 percent of the total energy consumption. Twenty-elght commerclal geothermally-heated greenhouses are In operation, many with very attractive payback periods. Products produced Include decorative flowers, potted plants, and hydroponlcally grown vegetables.

Geothermal heat for Industrial processing, although potentially very attractive, is used at only a handful of locations in the U.S. due to some extent to difficulties in relocating a commercial enterprise to a geothermal site. The total estimated value for direct heat geothermal utilization through industrial processing was derived from a sewage digestion plant In San Bernardino, Callfornia, a vegetable drying facility at Brady Hot Springs, Nevada, and copper processing at Hurley, New Mexico. The mushroom growing facillty at Vale, Oregon, was considered as a greenhouse.

The future growth of direct use applications may be impacted by the expiration of both the residential and business energy tax credits at the end of 1985. The maximum credit for residential use is 40 percent of the first $\$ 10,000$ of expenditures, or $\$ 4,000$, and the business credit is 15 percent.

CONTRIBUTIONS TO THE EMERGENCE OF THE "HOT WATER" INDUSTRY

How has an industry to ut111ze liquid-domlnated geothermal reservoirs for power generation and direct use applications emerged in spite of all of the technological and institutional barriers to 1 ts development? It has resulted from the interacting contributions of a number of forces at work to make it happen:

- the Interest and perseverance of many individuals and companies in the private sector

- the Industry-guided R\&D and commercialization programs of DOE and its predecessors

- the U.S. Geological Survey assessments of the slze and locations of the Nation's geothermal resource base

- the efforts of the Departments of the Interior and Agriculture to overcome the obstacles to timely geothermal lessing and permitting on federal lands

- more favorable federal tax treatment of geothermal production (depletion allowance and deductions for intangible drilling costs) and use (energy Investment tax credits for non-utility investors)

- state and local govermment actions to foster geothermal development.

Th1s 1ssue of the GPM chronicles many of the Industry/federal government contributions over the past 10 years. The state programs designed to support geothermal development w111 be addressed in an upcoming 1ssue.

\section{SUCCESS OF INDUSTRY EXPLORATION}

Industry Initiated geothermal exploration long before goverment interest in the use of the resource developed. From a historical perspective, the wells drilled at The Geysers 
in the 1920's are the earliest identified in the literature, although modern exploration appears to begin in 1955 with the Magma Power Co. exploratory work at The Geysers. Data compiled for the 1982 DOE report Hydrothermal Industrialization: Electric Power Systems Development on exploration in the major geothermal areas of interest show that Magma was also the first company to explore In Nevada - at Beowawe and Brady Hot Springs areas in 1959 and 1960 respectively. As identified by the study, the subsequent participants in geothermal exploration in the major areas have been about equally divided between oil companies, or their subsidiaries, and companies organized spectfically for geothermal development.

of the 27 hot-water areas listed by the report as having high and moderate levels of development activity, 15 are the sites of existing power plants, plants under construction, or planned plants.

$$
\begin{aligned}
& \text { Brawley - Union } \\
& \text { Coso - Callfornia Energy } \\
& \text { East Mesa - Magma, Republic } \\
& \text { Heber - Chevron } \\
& \text { Mono-Long Valley - Chevron } \\
& \text { (More recently, Mammoth } \\
& \text { Geothermal and Santa Fe Inter- } \\
& \text { national) } \\
& \text { Salton Sea/Niland - Union, Re- } \\
& \text { Westmorland - Republic } \\
& \text { public Magma } \\
& \text { Beowawe - Chevron } \\
& \text { Vulcan Thermal } \\
& \text { Brady Hot Springs - Magma } \\
& \text { Desert Peak - Phillips } \\
& \text { Dixie Hot Springs - Sunedco } \\
& \text { Steamboat Springs - Nevada Ther- } \\
& \text { mal } \\
& \text { Vale Hot Spr } \frac{\text { OR }}{\mathrm{Ings}}-\underset{\text { Amax }}{\operatorname{Republic}}
\end{aligned}
$$

Cove Fort/Sulphurdale - UnIon,

Roosevelt Hot Springs - Phillips

Vale Hot Springs is also the site of a large mushroom-growing facility utilizing the geothermal resource; the wells at Raft River, Idaho, and at the Valles Caldera, New Mexico, were drilled as DOE experimental wells; and development is Inhibited by environmental considerations at Lassen, California.

The other areas on the list not currently scheduled for power development, so far as is known to GPM, include:

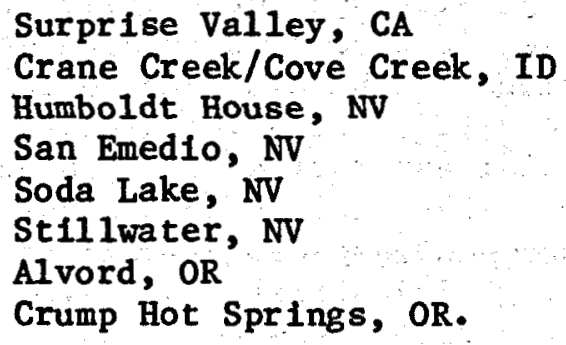

\section{ACCURATE RESOURCE ASSESSMENT}

In the 10-year period preceding the initiation of direct government involvement in geothermal energy, various organizations and individuals produced estimates of the geothermal resources of the United States. These estimates tended to vary widely, partially due to the differing assumptions and parameters that were chosen, but mostly because of an inadequate understanding of the nature and occurrence of geothermal resources.

In 1974, the U.S. Geological Survey initiated a comprehensive assessment of the geothermal resources of the United States which was published In 1975 as U.S. Geological Survey Circular 726. This was the first systematic effort to estimate the geothermal resource potential of 
the U.S, and to create a methodology and framework for directing long-term energy policy and strategy.

In 1978, the USGS reevaluated the geothermal resources of the United States in light of new available nonproprletary data and refinements in geothermometry (U.S. Geological Survey Circular 790). The estimate for the number of hydrothermal systems with temperatures over $90^{\circ} \mathrm{C}$ (excluding those In national parks) dropped from 283 in 1974 to 215 in 1978.

The first quantitative assessment of thermal energy contained within low- and moderate-temperature systems (1ess than $90^{\circ} \mathrm{C}$ and $150^{\circ} \mathrm{C}$ respectively) was completed by the USGS in 1982 (U.S. Geological Survey Circular 892). Data for the assessment were generated by "Resource
Assessment" (RA) teams through cooperative Department of Energy and state direct use program agencies. The results of these data gathering activities were published as a series of reports and state geothermal maps for prospective direct heat users.

This Information, in addition to that generated by the USGS Geothermal Research Program and the Regional Aquifer System Analysis Program, was entered Into the computer-based GEOTHERM system malntained by USGS. Data on more than 2500 individual geothermal systems were evaluated.

The results of the USGS geothermal assessments are summarized below.

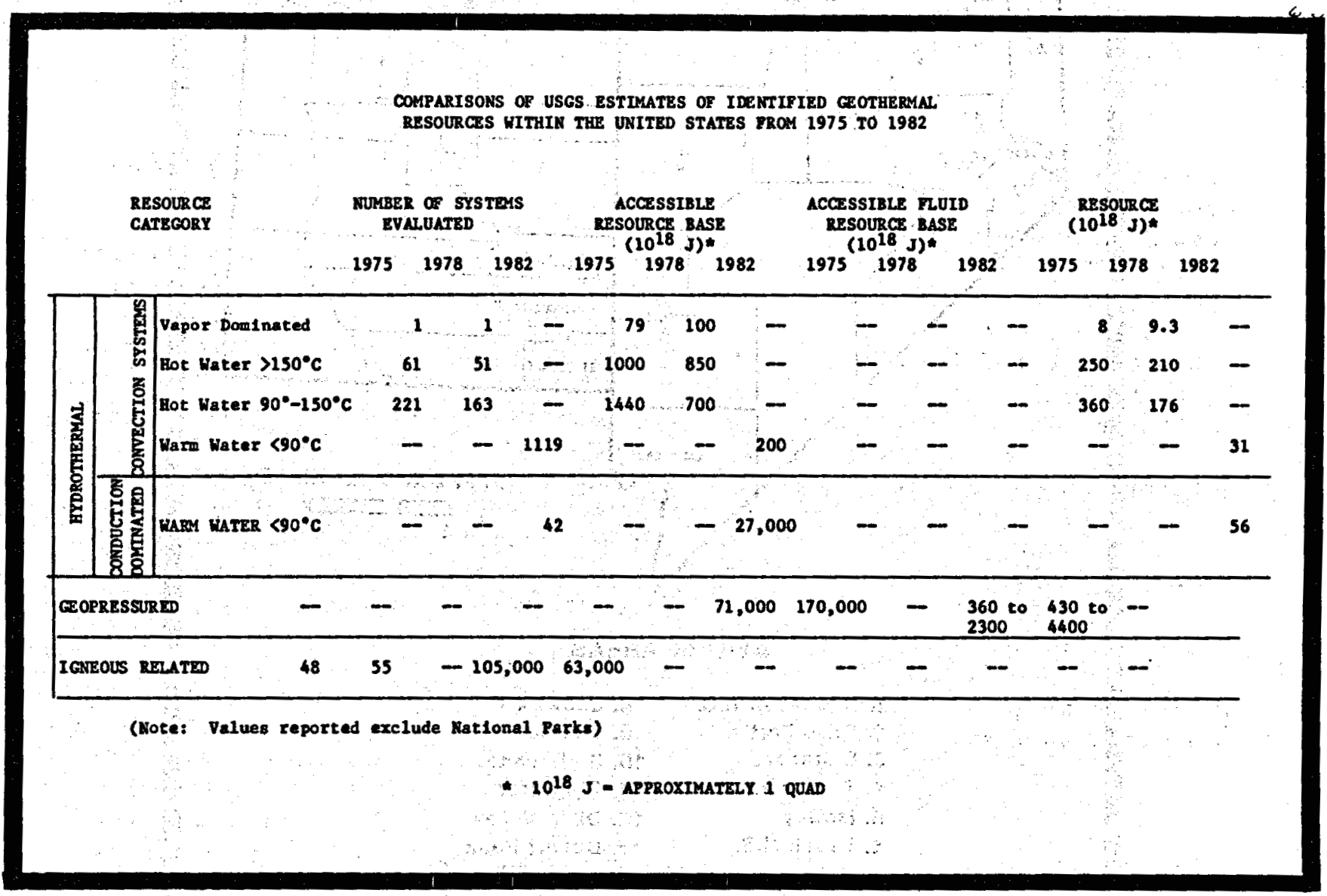




\section{EXTENDED GEOTHERMAL}

\section{DATA BASE}

When interest in geothermal utilization mounted in the 1970 's, a working data base for geothermal resources did not exist. Energy companies, in order to protect land and resource positions, tended to guard exploratory and development data as proprietary, and there were no other sources of data due to the "newness" of interest in the resource.

In response to this problem, a number of programs were initiated by
DOE's predecessor, ERDA, In the mid$1970^{\prime}$ s. The Industry-Coupled CostShared Program was organized to evaluate selected hlgh-temperature geothermal systems; the State-Coupled Resource Assessment (RA) Program undertook to compile regional geothermal data; and the User-Coupled Confirmation Drilling Program provided a means of cost-sharing the high frontend risk portion of direct use exploratory drilling.

\section{LOCATIONS OF NDUSTRY-COUPLED PROGRAM AREAS}

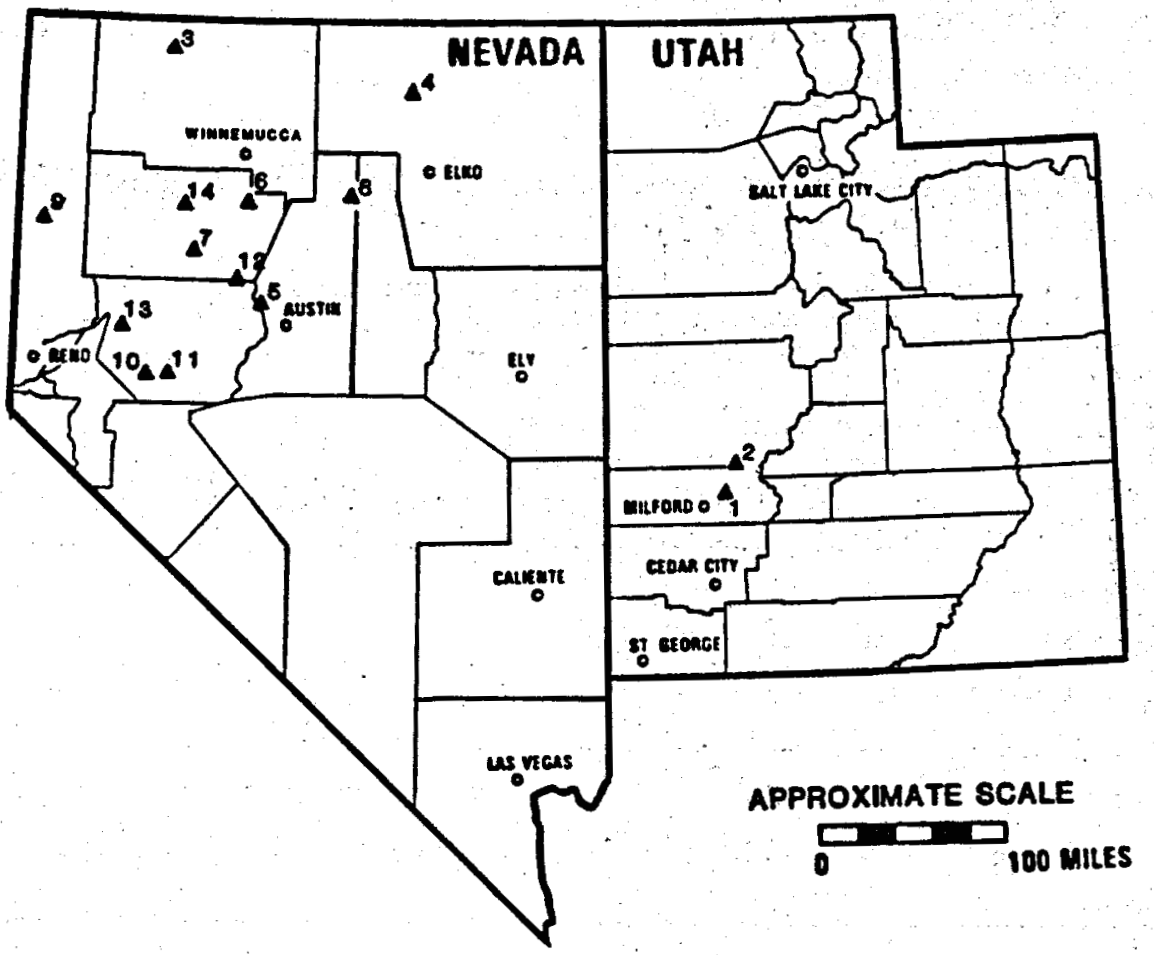

AWORK AREAS
1. Roosevelt H.S.
8. Beowawe
2. Cove Fort
0. San Emidio
3. Battazor
10. Soda Lake
4. Tuscarora
11. Stillwater
6. McCoy
12. Dixie Valley
6. Leach H.S.
13. Desert Peak
7. Colado
14. Humbolt House 
The INDUSTRY-COUPLED PROGRAM was Inftlated to accelerate the commerclalization of geothermal energy by (1) stimulating industry exploration efforts through cost (and thereby risk) shering, (2) making data generated from the program avallable for unrestricted use, (3) developing case histories of geothermal exploration in various geologic environments for determining optimum exploration techniques, and (4) confirming resource potential at selected geothermal sites. The program included 21 deep exploratory wells with an average depth of about 7000 feet, numerous shallow thermal gradient test holes, and geosclence Investigative surveys.
Nine major data packages with detalls of these results may be studled free-of-charge at the University of Utah Research Institute, Earth Sclence Laboratory In Salt Lake City, or may be purchased by mall. A geothermal sample library containing cuttings and core samples from various DOE-sponsored programs is also maintained at UURI/ESL for study.

The STATE-COUPLED RESOURCE ASSESSMENT program was organized around geoscience expertise from state geological surveys, unfiersities, and state water resource agencles. Phase I centered on the gathering of temperature, chemical, and productivity data from known thermal springs and wells

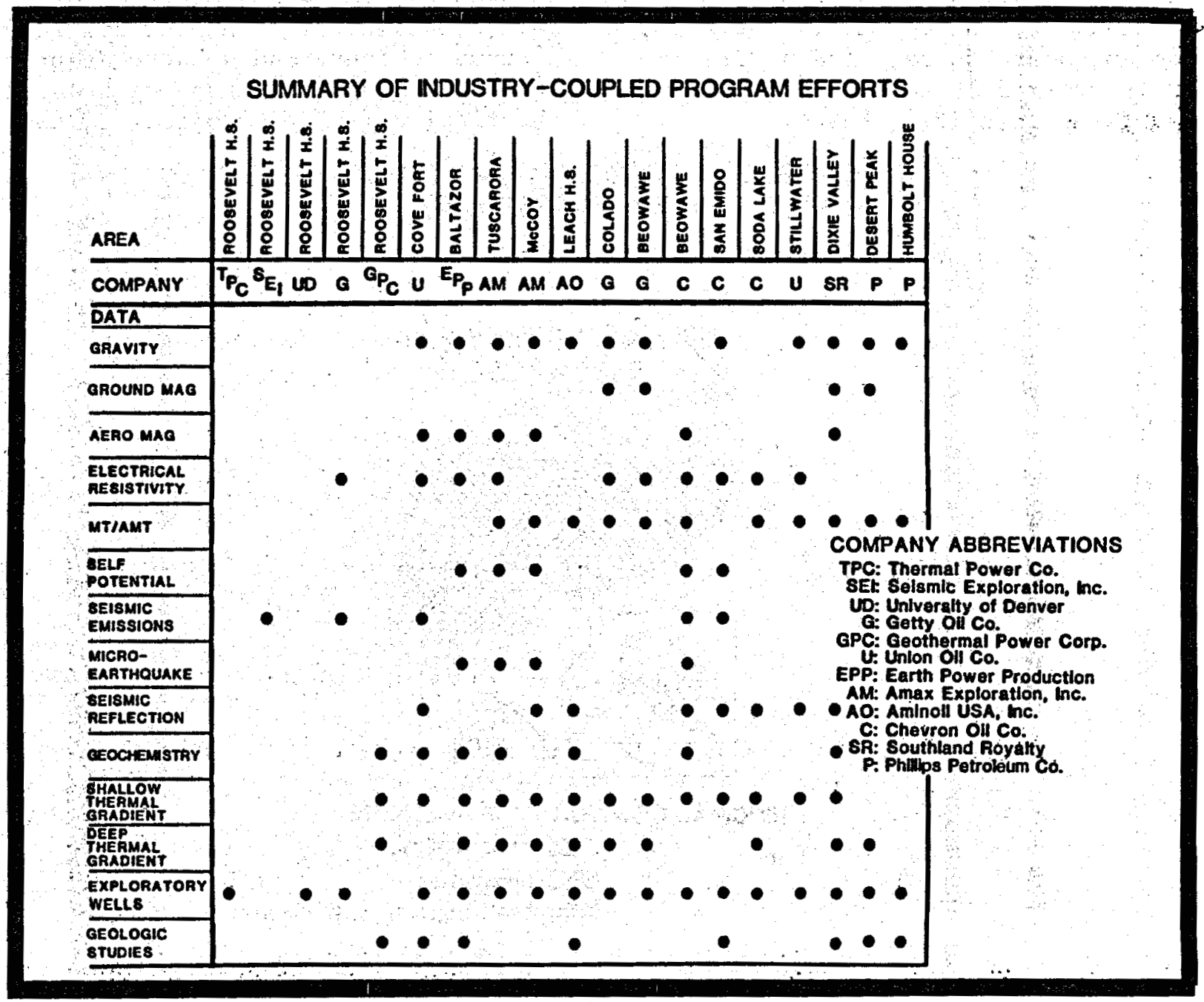


in order to define and prioritize new low- to moderate-temperature geothermal exploration targets. Data compiled were contributed to GEOTHERM. In Phase II, regional reconnaissance Involved a more detalled look at the geothermal data gathered in Phase I in order to refine exploration target models and to outline optimum geothermal enviroments.

Publication of 18 state maps depicting thermal springs and wells (temperature, flow, depth, and TDS), areas potentially favorable for new discovery, and the outline of federal and state KGRA's was an important part of the State-Coupled Program. They are available through the National Oceanic and Atmospheric Administration. More technical maps for New Mexico and California were also produced. During the course of the program, over 150 detalled studies were performed at selected sites in the states Identified below.
The effect of these programs on the success of geothermal commercialization will not be fully realized for a number of years. Data developed from the Industry-Coupled program, however, are undoubtedly alding geothermal electric power development in the Basin and Range.

The USER-COUPLED CONFIRMATION DRILLING PROGRAM was initiated in 1980 to promote direct uses of geothermal energy by establishing a predetermined cost-share schedule with an industry participant based upon the degree of success of the project. It was modified, however, by a shift in DOE policy away from direct, financial incentives to promote the adoption of specific technologies. From an initial submission of 25 proposals, nine were selected for participation. This number was later reduced to four, and subsequent problems with proposer financing reduced the final number of projects to two,

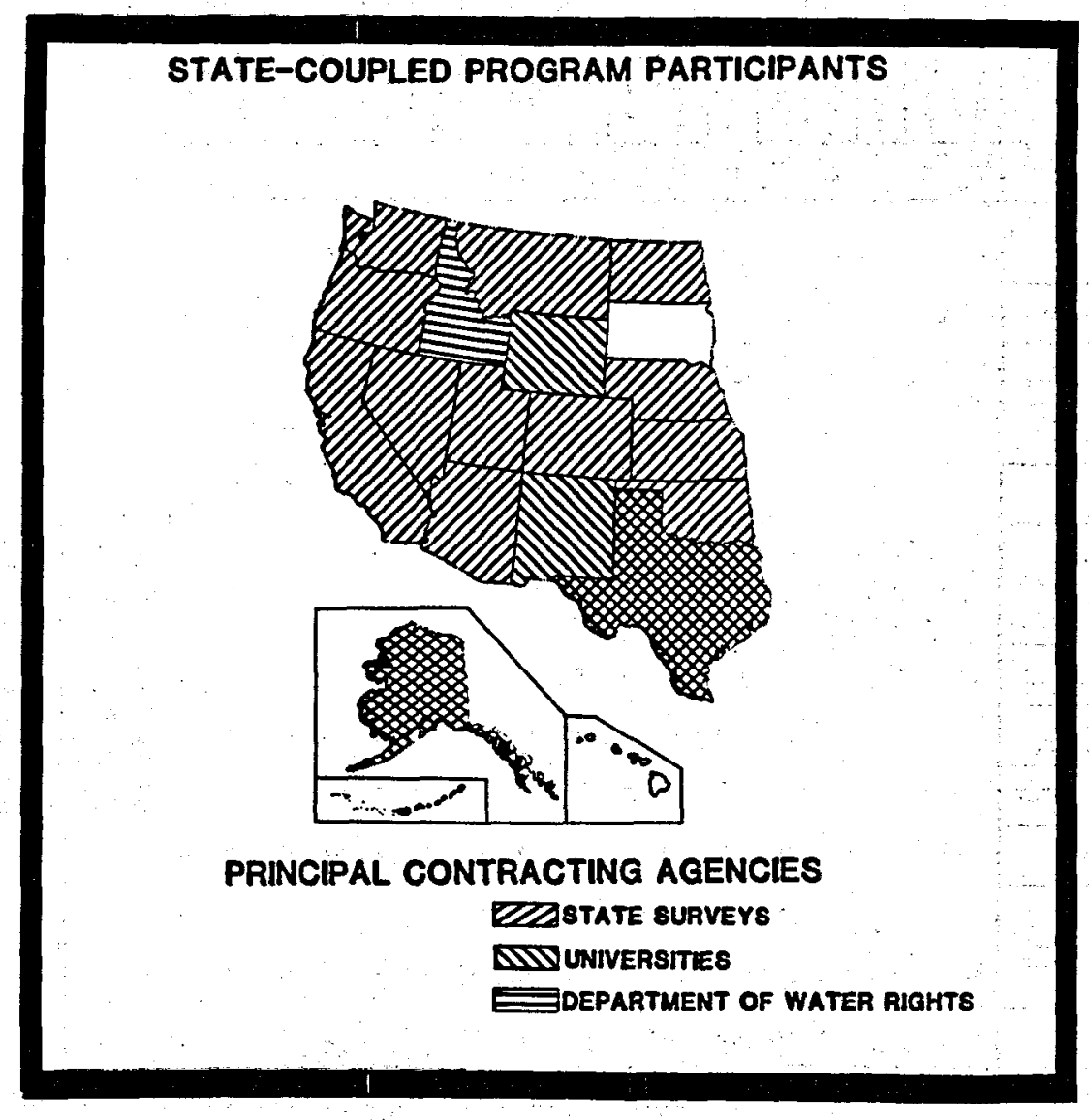


one at Alamosa, Colorado, and the other in the Wendel-Amedee area near Honey Lake in northern California. A production well at Alamosa was shutin and abandoned after testing. The well at Honey Lake may be used to provide low-temperature flulds for a hybrid binary power plant under deve1opment by Geoproducts Co.

\section{IMPROVEMENTS IN PREDICTIVE TECHNIQUES}

In the late 1960 's and early 1970 's, exploration methods for geothermal energy were adapted from the petroleum and mining industries, or were based upon methods used in historically established geothermal ereas (1.e., The Geysers and Larderello, Italy), with only partial success. The need to develop better predictive methods became evident when exploration moved to the 11quiddominated geothermal enviroments.

A number of programs sponsored by DOE and USGS over the past few years have addressed these problems. Case history development from DOE's Industry-Coupled Program Identified the suitability and limitations of various exploration methods and permitted the relative usefulness of the various techniques to be determined. Conventional geophysical methods were subsequently modified to account for the nature of geothermal systems.

Improvements in chemical geothermometry by the USGS and others have allowed for the determination of prospective geothermal targets. Early interest in the mid-1960's on sillca concentrations of natural water systems evolved through the use of sodium, potassium, and calcium concentrations in empirically-derived equations. Correction factors for these equations using other dissolved constituents (e.g., magnesium) were later introduced to better estimate reservoir equilibration temperature. : State-ofthe-art methods in chemical geothermometry currently incorporate the use of chemical thermodynamics and kinetics in the development of mixing models.

USGS research efforts have paralleled DOE's by program interaction and ongoing scientific research. Major geoscience accomplishments of the Geothermal Research Program of the USGS include:

- multidisciplinary studies of selected geothermal regions

- geothermometry development

- electrical and electromagnetic technique development

- refinement of passive and active seismic methods

- mathematical modeling of hydrologic systems.

The current DOE emphasis in hydrothermal reservoir research is directed at parameters that individually characterize producing hydrothermal systems. Research is under way for improvements in techniques to predict reservoir behavior under longterm production/injection of geothermal brines and to determine reservoir limits and controlling factors.

Various exploration methods, their usefulness, and present status are summarized on the next page. 
USEFULNESS AND PRESENT STATUS OF VARIOUS EXPLORATION TECHNIQUES

\section{METHOD}

1. Thermal Gradient/Heat Flow

2. Gravity

3. Electrical Resistivity

4. MT/AMT

5. Self Potent1al

\section{APPLICATION}

- Direct detection.

- Low-cost delineation of Shallow Babin. Structure.

- Low Resistivity Zones related to hot fluld clrculation. Best detection of high angle structures.

- Although used for detection to great depths, can be linited by surficial conductors.

- Low-cost detection of Basin structure. Best in late stage of exploration.

- Detection of selsmic emisslons related to hydro-

7. Refiection Setomic

8. Magnetics

9. Geologic Mapping

10. Geochemistry thermal activity.

- Cost-effective delineation of Border Faults and depth of alluvial fill.

- Aeromagnet1c surveys usefu in determining regtonal structure.

- Low-cost regional and ares studles.

- Estimating reservolr equilIbration temperature.
STATUS

- Currently recognized as most valuable Indicator of thermal anomaly.

- Better resolution with Improvements in quantitative numerical modeling.

- Numerical modeling techniques help produce intrinstc resiativity maps to depths of $500 \mathrm{M}$.

- Research for application stil ongoing:

- Ut1lity uncertain.

- Recognition of Iimitations within areas of thick alluvial cover. Method may not be cost-effective.

- Improvements in digital processing may reduce problems assoclated with near-surface volcanics.

- Identified limttations Include Interference from Reversely Polarized volcanic units, prisin model development, Interaction in complex geologle settings.

- Currently recognized as Important component to site-specific exploracompone to slte-specific explor tion programs, espectally where aults intersect.

- State-of-the-art methods Include the use of chenical thermodynamics, development of "mixtng" models, studies of 1sotope fractionation. Isotope ratios give a siaple and cheap initial idea of thermal conditions. 


\section{ADVANCED DRILLING TECHNIQUES}

In 1975, a federal program was initiated to improve rotary techniques for geothermal drilling in the hot, corrosive, and hard fractured rock geothermal environment. Since 1977, this program has been managed at Sandia National Laboratories, Albuquerque, New Mexico. The nearterm goal of this research is to bring about a 25 percent cost reduction in conventional geothermal driling. In the long term, a 50 percent cost reduction through the Implementation of advanced drilling techniques is targeted.

DRILLING HARDWARE: One of the success stories in the geothermal R\&D program is the unique adaptation of PDC (polycrystalline diamond compact) cutters to dril1 bits. "By 1981 , five percent of all bits sold in the U.S. were PDC bits, and $1 t$ has been estimated that this share w111 Increase to 50 percent by 1990 ; wh a large percentage used for oll drilling.

The Sandia bit hydraulics test stand permits the fluid flow around drill bits to be visualized and has Indicated that some cutters in commercial drill bits were poorly situated. Simllar facilities have since been Installed by at least one major bit manufacturer for use in improved bit design and cutter placement.

An unsealed roller cone bit and the required high temperature lubricants for this equipment are now on the market as a result of this program. Currently, the wear resistance of a much less expensive refractory material, niobium carbide, is beling tested to determine the sultability of this material as a replacement for tungsten In bit Inserts.

The use of cavitating nozzles has been ploneered to Increase the efficlency of conventional drill

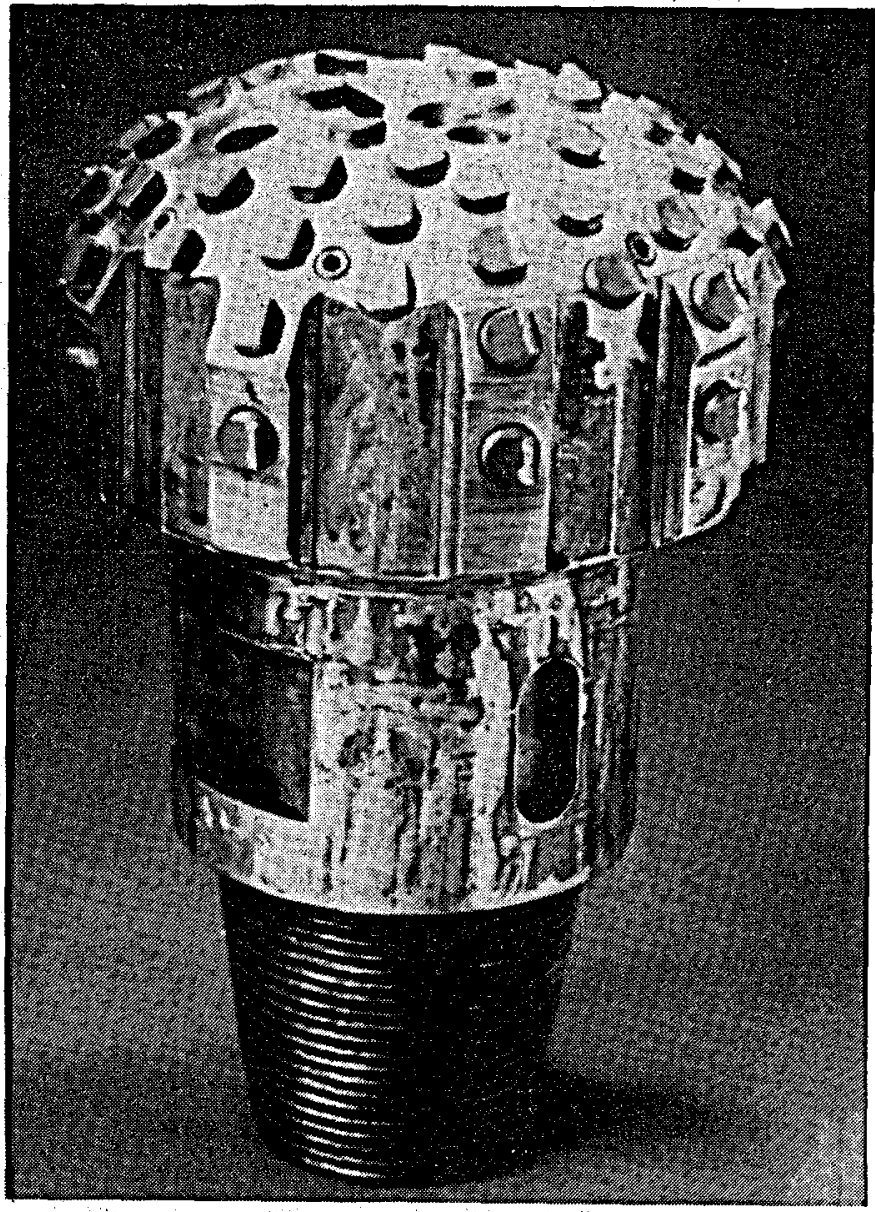

A polycrystalline dlamond compact (PDC) drill blt.

bits. These nozzles cause bubbles to form in the fluid exiting the drill bit. When the bubbles contact the rock surface, they collapse violently; weakening the rock and aiding the drill bit cutters.

Non-conventional drilling systems that were developed as far as prototype designs include the chain. bit, with downhole replaceable cutters, and the Terra-drill, a bit that fires ceramic projectiles (bullets) into the formation to weaken $1 t$ and Increase the drilling rate.

In order to Improve drili bits and associated tools, Sandia Is seeking to Increase the knowledge of downhole conditions through drill string dynamics modeling. The Impor- 
tance of this project to industry is demonstrated by the fact that there are five industry co-sponsors (NL Baroid, Mobil 0i1, Sohio, Conoco, and Arco). Downhole conditions are also simulated by GEOTEMP, a computer program that calculates the temperature profile in a well, and downhole drilling mud properties are measured on-site by a high-temperature, high-pressure viscometer.

DRILLING FLUIDS: A major contributIon of the federal geothermal program is the development of hightemperature geothermal driling fluids. The temperature range of conventional muds can be Increased by using fibrous clays developed by the on-going clay studies program, and aqueous foams that can survive temperatures up to $260^{\circ} \mathrm{C}\left(500^{\circ} \mathrm{F}\right)$ have been ploneered.

LOST CIRCULATION: LOSS of drilling fluld into fractured or high permeability zones is the most costly problem in geothermal drilling overa11. Thus, a Lost Circulation Test Facility has been constructed and is used for simulating downhole tests of potential lost circulation materials. Computer models are also being used to Identify the "Ideal" lost circulation fluid.

INSTRUMENTATION: Significant advances in the development of hightemperature electronics have been made. Component development has resulted in a $275^{\circ} \mathrm{C}\left(527^{\circ} \mathrm{F}\right)$ operational amplifier, multiplexor, and hybrid circultry (voltage regulators, line drivers, pulse stretchers, V/F converters).

Experimental logging tools have also been developed, including the Wellbore Inertial Navigator (borehole directional survey accurate to $1 \mathrm{~m} /$ $1000 \mathrm{~m}$ depth) and the prototype High-Temperature Acoustic Borehole. Televiewer (capable of operating to $\left.275^{\circ} \mathrm{C}\left(527^{\circ} \mathrm{F}\right)\right)$. The televiewer has been successfuily run for the Geothermal Division of Union 011 in the Imperial Valley, yielding valuable information on casing condition and fracture location. Temperature sensors and a variable logging speed capability are being added to the televiewer to modify it for use as a Lost Circulation Zone Mapping Tool.

Other ongoing projects include the High-Temperature Cement Bond Log Tool, H1gh-Temperature Mono-Cable Tools (temperature, pressure, and flow measurements for production/injection logging), and the Radar Fracture Mapping Tool (using VHF electromagnetic signals to "see" fractures tens of meters away from the borehole).

\section{IMPROVEMENTS IN MATERIALS}

Initial geothermal energy projects borrowed materials and fluid engineering techniques from other Industrial applications, largely oil production. Short well and equipment Iife and/or low process efficiency resulted because of the high-temperature, corrosive geothermal enviroment. In addition, numerous, and occasionally very costly, materials failures were experienced in the field, due to the unavailability of appropriate materials; a lack of awareness of suitable materials already existing; or a lack of knowledge about geochemical characteristics and behavior. Inefficient or ineffective components and systems were designed and occasionally constructed on the basis of erroneous or incomplete geochemical data. In addition, the Inaccuracy or unavailability of monitoring systems often prevented the constant monitoring and data analysis required to maintain peak performance and avoid downtime of even a properly designed energy facility. The materials problems faced by the geothermal industry In the $1970^{\prime} s$, the DOE R\&D response, and the materials breakthroughs that 
are now available as "of $f-t h e-s h e l f$ " products and components are Identifled on the next page.

\section{DEVELOPMENTS IN POWER CONVERSION TECHNOLOGY.}

Industry $1 \mathrm{~s}$ currently commercializing the flash steam technology on its own, with minimal recent assistance from government. DOE, on the other hand, has been concentrating Its resources on binary technology in an effort to reduce its cost to a level that will be economically attractive for the use of moderatetemperature reservolrs $-150^{\circ}-200^{\circ} \mathrm{C}$ $\left(302^{\circ}-392^{\circ} \mathrm{F}\right)$.

\section{LESSONS LEARNED AT THE GLEF}

By the early 1970's when the U.S. federal geothermal program was born, hot water geothermal resources were belng successfully utilized in flash steam plants In Mexico, New Zealand, and Japan.... Interest in using the hot water reservolrs in this country developed concurrently and focused particularly on Impertal Valley, drawn especlally by the high temperatures of the Salton Sea reservoir. This very hot, hypersaline reservolr was the subject of exploratory drilling through the $1960^{\prime} \mathrm{s}$, and the temperatures found $-260^{\circ}-300^{\circ} \mathrm{C}$ $\left(500^{\circ}-600^{\circ} \mathrm{F}\right)$ - were unlquely sulted to the flash steam technology. However, 1 ts un Ique salinity levels - $250,000 \mathrm{mg} / \mathrm{l}$ or over eight times the salinity of sea water - posed operating and materials problems not encountered in the development of the technology abroad. A binary cycle was Inttlally selected as a power plant design for the site, but fleld tests indicating poor heat exchanger performance due to silicate scaling led to the final design of a fourstage flash/binary process.
DOE's predecessor, ERDA, jolned the original team of San Diego Gas and Electric Co. (SDG\&E) and field developers Imperial Magma and New Albion Resources Co. (NARCO, a subsidiary of SDG\&E) in constructing the first, and highly integrated, cooperative, jointly-funded government/industry. geothermal demonstration facillty the Geothermal Loop Experimental Facility (GLEF). The facillty was completed in 1976 to determine the technical and economic feastbility of generating electricity from highly saline brines.

After operating for two years on the origlinal system, the test data Indicated that this was not the best system for the Salton Sea reservolr brines, although many problems had been resolved. A subsequent feasibilIty and risk study identifled the dual stage flash cycle as the optimum technology, with scallng, corrosion, and injection as the major remaining risks. After a year's operation with this technology, a clarifier/filter brine treatment system to reduce infection well plugging was added. Sollds removed downstream of the flash tank were added upstream to provide nucleation centers to reduce precipitation as scale. Th1s equipment has proved to be a major breakthrough in ut11izing highly saline brines. After generally successful tests of this system, the GLEF operation was terminated in the fall of 1979. A turbine was never added to the facility.

The four-stage flash/binary process demonstrated that relatively clean flashed team can be produced from the saline brines and that avallabllity factors of at least 60 percent can be achleved. The twostage conf Iguration demonstrated several successful scale removal techniques and provided evidence that acceptable capacity factors appeared to be feasible wh added flash trains.

Thus, it was determined that com- 


\section{PROBLEMS}

- H1gh cost of materials due to:

- High temperature:

and preseures

- Corrosive and erosive

fluids

- Short 11fetime

- Lack of materials performance data

- Foullng and scalling

- Poor understanding of fluid behavior/cooplex chemistry

- Unrellable sampling and analysis procedures

MATERIALS PROBLEMS IN GEOTHERMAL DEVELOPMENT,

DOE MATERIALS PROGRAMS, SOLUTIONS/IMPROVEMENTS

\section{DOE PROGRAM OBJECTIVES}

- Identify alternate high-temperature, corrosion-resistant materials to costl metals for borehole and energy conversion components

- Test corrosion inhibitors and monitor

- Research cathodic and anodic protection

- Develop corrosion data base

- Develop Improved downwell and power plant Instrumentation

- Collect, analyze, and document field performance data

- Develop solids and scale control methods

- Model scale deposftion and multi-ion fluide

- Develop sensors for monitoring

- Chemical and kinetic studies

- Measure infectability of brine

- Evaluate exloting sampling and analysis methods and develop new techniques

\section{SOLUTIONS/ TMPROVEMENTS}

Mathematcal model to calculate temperature changes in wells

- High temperature equipent and materials:

- hybrid electronic c1r-

hybr:

- elastomeric seals and oringe

- open tole packer

- well completion cement

- lubricants, grease, and$$
\text { muds }
$$

- dornhole alectric cable and cablehead equipment

- Corrosion resistant equipment and ater1als:

- downhole flow meter

- well casing materlala

- polymer concret

- downhole pumps

- pressure lubrication systen

- non-metallic heat exchanger tubing

- Steels for Improved drill bit IIfe for fluids up to $400^{\circ} \mathrm{C}$
- Wear resistant tungsten carbide and N1-Cr-SI-B IIne shaft preap coatings

- Improved roller cone bits, diamond dri11 bit

- Effective carbonate acale control agent

- Flash crystallization/thicken1ng procesis

- B1nary aystem leak detector (e.g., sensors, particle counters )

- On-line suspended sollds monitor for injection

- Summary document on samp1ing/analysis techniques

- Guldell nes/handbooks on materials selection, high temperature electronic components, and infection treatment 
merclal power generation wi th flash steam technology using highly saline brines would be technically and economically feasible. The significance and application of the brine treatment system developed at the GLEF to commercialization of this type of resource is discussed below In connection with other developments in brine injection.

\section{INDUSTRY'S DEMONSTRATION OF FLASH STEAM TECHNOLOGY}

The first U.S. power plant built to Incorporate the flash steam technology was the Southern California Edison/ Union 011 Co. 10 MWe plant at Brawley, California, which came on-11ne in June 1980, a short distance from the GLEF site. The fluids of the Brawley reservolr are only somewhat less chemically hostile than those of the Salton Sea reservolr, contalning approximately $100,000 \mathrm{mg} / 1$ of dissolved solids. Fluid temperature is in excess of $204^{\circ} \mathrm{C}\left(400^{\circ} \mathrm{F}\right)$.

The plant had the benefit of both the GLEF experience and earlier SCE power generation experiments with wells at the Salton Sea. To mitigate problems anticipated due to the impuritles in the fluid - not normal to conventional steam plants - and to maintain reliability, redundant systems were installed in the plant and certain systems incorporated special materials. The modular energy conversion system, supplied by Mitsubish1 Heavy Industries, Inc., is patterned after a plant in Japan that has been operating since 1973 .

The plant of fers SCE and coowners (a consortium of the Los Angeles Department of Water and Power and the municipal utilities of Pasadena, Riverside, and Burbank) a facillty for geothermal research, operating experience, and information on geothermal energy utilization with highly saline brines. It provides
Union the avallability of a plant to demonstrate and maintain a continuously operating brine production and injection system.

Monitoring of the Brawley fac1lity by the Imperial County Department of Public Works has detected no adverse environmental impacts. Agricultural operations continue up to the edge of the project site.

In 1982 , another SCE 10 MWe flash steam plant came on-line near the Salton Sea. Union was designated as field operator by its partners in large leaseholdings in the area, Southern Pacific Land Co. and Mono Power Co. These companies conducted a fleld development program including drilling several new wells and construction and operation of fluid production/brine handling test facilitles to determine the best methods to produce, handle, and Inject the high salinity brines.

This plant has operated relative1y smoothly from the start which is in large part due to a closed crystallization system for brine handling developed during these experiments to concentrate the sollds. Scaling and corrosion problems are not all resolved at this plant, but operation was optimized by Incorporating improvements indicated by operations at the Brawley plant.

Af ter four years of operation, the latter has achieved a cumulative on-line factor of 71 percent, and a cumulative capacity factor of 35 percent. During one 14-month period, these flgures were increased to 76 and 44 percent respectively. After two years of operation, the cumulative figures for the Salton Sea plant are 83 and 75 percent. The two plants together have produced approximately 220 million $\mathrm{kWh}$, the equivalent of 370,000 barrels of oil. 
LESSONS LEARNED AT BACA

In 1977, Congress authorized DOE to cost-share a 50 MWe plant with industry to demonstrate commercialscale flash steam technology and to serve as a "pathfinder" for the regulatory process and other legal and Institutional aspects of geothermal development. Such a plant was planned for the Valles Caldera in north central New Mexico, site of the Baca reservoir, with particlpation by the Union $011 \mathrm{Co}$ and the Public. Service $C_{0}$. of New Mexico.

Union had conducted considerable exploration in the area for several years, and its successful wells and surface geologic, geophysical, and geochemical surveys Indicated that there was very little risk that the reservolr could not support plant requirements. In addition, the U.S. Geological Survey had estimated that the reservoir would support 2700 MWe capacity for power generation. The resource falled, however, for reasons that are still not clearly understood, a failure that has led to disagreement In the scientific community as to the geologic features responstble for the high-temperature, hot water production at Baca.

The result of the reservolr fallure to produce as expected was mutual agreement in January 1982 to abandon the project. However, all parties to the project felt that, although it did not serve its intended purpose, many valuable lessons were learned, and considerable experience for future application was galned from it. In addition, the wealth of data gathered at Baca will provide guldance to the National Academy of Sciences Continental Scientific Drilling Project.

\section{INDUSTRY'S DEMONSTRATION OF - BINARY TECHNOLOGY}

Concurrently with its Involvement with the GLEF, Magma Power Co. designed and constructed a 10 MWe dual binary plant at East Mesa which came on-line in January 1980. The plant is currently operating efficlently, and the power generated is sold to Southern California Edison. However, this level of performance was achleved only after solutions to initial difficulties were found.

This plant utilizes the patented Magmamax process which pumps the hot geothermal fluid through a heat exchanger where isobutane working fluid is vaporized to drive a turbine. The vapor 18 condensed by coollng and returned to the heat exchanger system. The spent geothermal fluid is injected back Into the reservolr to complete an environmentally-benign closed cycle. A second parallel power loop uses propane as a working fluid.

After two years of spasmodic operation, a major reconstruction was undertaken under the direction of the Dow Engineering Co. A new main turbine was Installed along with redesigned heat exchangers. Since starting up again in the fall of 1982, the plant has achieved a high avallability operation of over 98 percent. A she11-and-tube heat exchanger is employed wth the very benign East Mesa reservolr fluld which contains only about $7500 \mathrm{mg} / 1$ of solids.

\section{DOE'S BINARY RED}

DOE efforts to reduce the costs of binary cycle technology are focused on three major components - heat cycle effictency, optimum working fluids, and downhole pumps that will function properly in the high temperatures and chemical environments of geothermal wells. The Heat Cycle Research Facllity (HCRF), a $60 \mathrm{~kW}$ experimental binary cycle, has been used extensively to investigate varlous concepts and/or components. It was first employed at the Raft River Geothermal Site In southeastern 
Idaho to test a she11-and-tube binary cycle. The principal objectives achleved were: 1) operational experience with a binary cycle facility of a size that would allow the experience galned to be generally applied to full size power plant operation; 2) demonstration that cycle prediction methods and fluid properties result in satisfactory component and plant performance; and 3 ) demonstration of the feasibility of running a binary geothermal power plant in an automatic run mode.

The HCRF was then modified to incorporate a sieve tray directcontact heat exchanger (DCHX) in order to confirm thermodynamic analyses that indicated that direct contact cycles should be able to attain geofluid effectiveness levels essentially equivalent to those produced by shell-and-tube binary cycles. The DCHX units themselves would be less costly than the expensive internal components needed for shell-and-tube exchangers and would have the added advantage that they contain no heat transfer surface to be fouled by the geothermal fluid. However, in this type of heat transfer, working fluid is entrained and dissolved in the geothermal fluid which necessitates recovery of the working fluid to minimize losses.

In tests of the sleve tray DCHX at Raft River and extensive testing of an open column $500 \mathrm{~kW}$ DCHX unit at DOE's East Mesa Geothermal Test FacilIty (GTF), some with pure hydrocar-

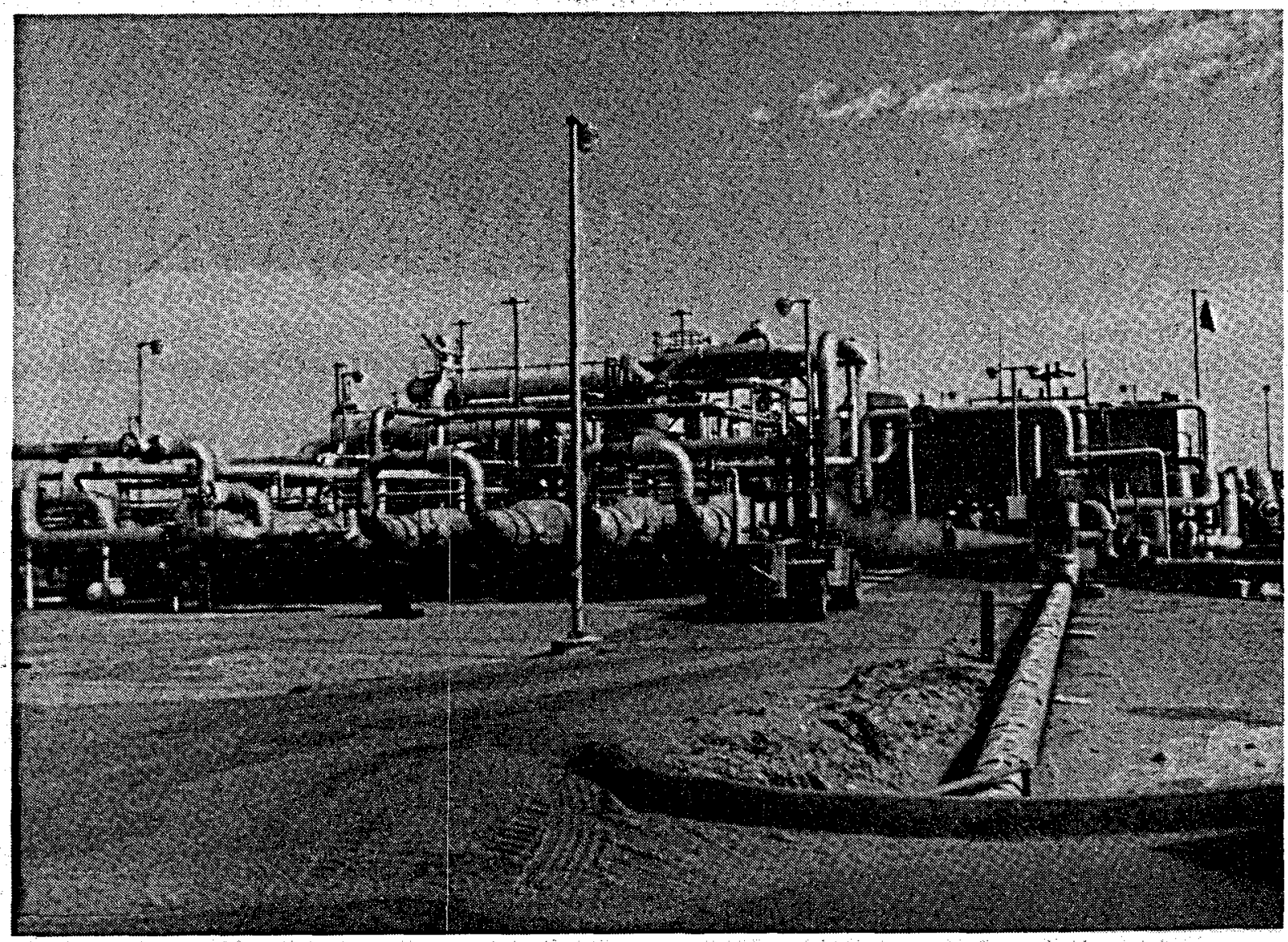

Magma Power Co. geothermal binary power plant at East Mesa, being enlarged from 10 to $12.5 \mathrm{MWe}$. 


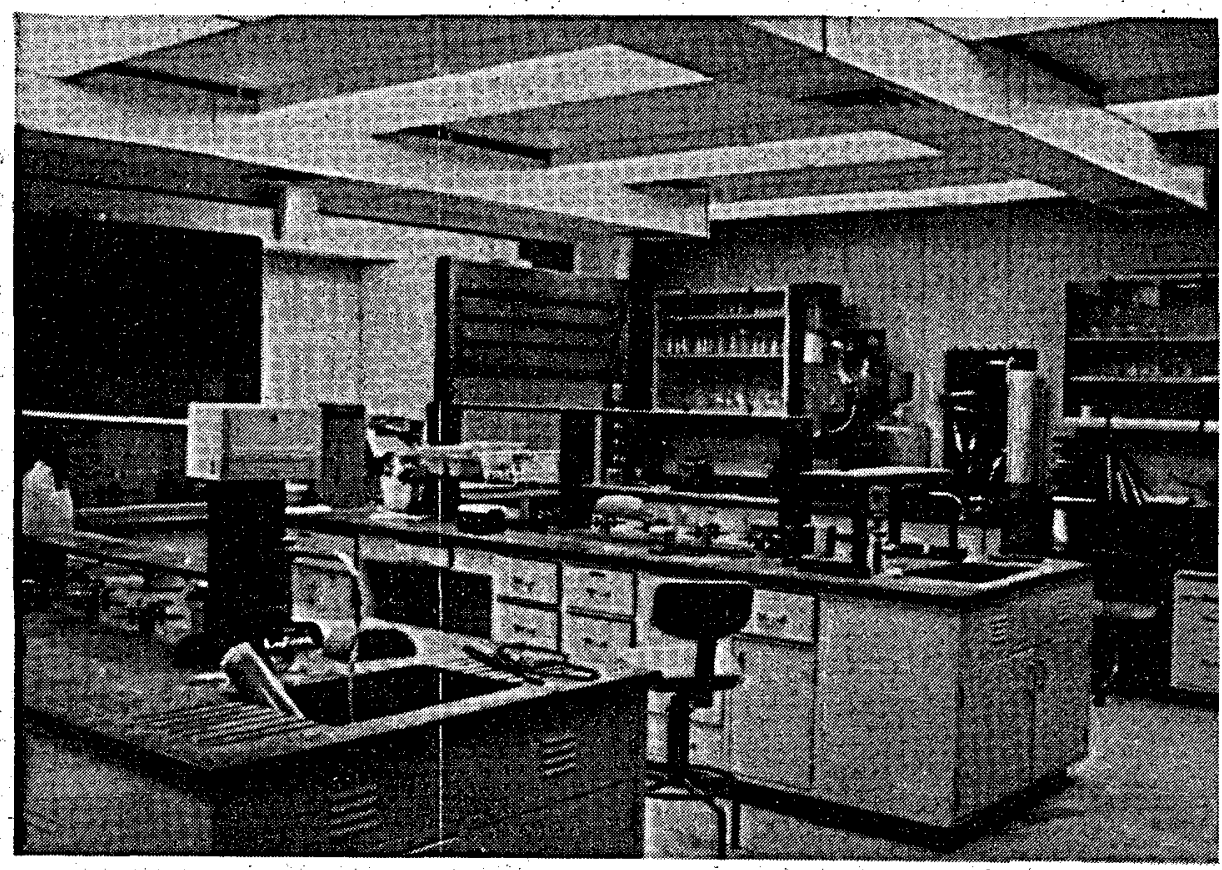

Chemical laboratory avallable to the public at DOE Geothermal Test Fecility (GTF) at East Mesa, California. Open to private and institutional. experimenters at a nominal charge, the facllity also provides goothermal fluid and support services for tests of heat extraction and energy conversion equipment and materials. The laboratory is equipped with modern, sophlsticated equipment such a 8 an atomic absorption spectrophotometer and a gas chromatograph.

bons and some with fluid mixtures, both achieved excellent heat exchange performance. However, these tests have shown that due to the added costs of working fluid recovery and other ancillary equipment needed to operate the DCHX units, there is no particular economic value in their use with benign flulds that permit the use of moderate-cost heat exchanger tubing. On the other hand, the tests have also shown that if a resource requires the use of exotic tubing materials that would adverseIy Impact the cost of electricity produced, the direct contact heat exchanger could become an economically justifiable alternative. Testing of a hypersaline brine is planned for the future.

The HCRF has now been moved to the GTF where it is operated currently as a supercritical cycle. Condensing of the working fluid is accom- plished by a single countercurrent flow heat exchanger with the working fluld in the tubes. After tests with the condenser in a vertical attitude, tests will be performed at other positions.

Early conclusions from these tests Include:

- A geothermal power system utilizing a hydrocarbon $\mathrm{mlx}-$ ture as a working fluid with a supercritical cycle is operable.

- The thermodynamic and transport properties of the DOEfunded National Bureau of Standards computer code EXCST are the most accurate in predicting the thermal behavior of the heat exchangers.

A larger binary unit - 5 MWe -- 
was also installed at the Raft River site to test performance with 1 sobutane and state-of-the-art components. Completion of the plant coincided with reduced federal budgets, and only short-term tests were conducted. On the basis of calculated results, the performance of the system was approximately as predicted, and component problems were determined to be the cause of a somewhat lower power output than anticipated. The tests Ind lcated that the system is technically viable and permitted formula$t$ ion of recommendations for future use of this type of equipment.

DOE also funded development of another type of binary plant called the "gravity-head" system. In this technology, the primary heat exchanger is utilized downhole in the production well, an arrangement projected to allow better matching of inlet/ outlet conditions, and thus to increase the net power output by about 50 percent over that of conventional binary plants under equivalent conditions and costs. This equipment may see commercial operation in the near future.

Improvements in electric submersible pumping systems have resulted In a demonstrated downhole running 1ife of one year for low horsepower unlts operating in $177^{\circ} \mathrm{C}\left(350^{\circ} \mathrm{F}\right)$ brine. A prototype pressurized lubrication system to prevent brine intrusion and loss of lubricating oll from the motor and protector sections has been successfully tested. Second generation pressurized lubrication systems have been designed, and a prototype metal-sheathed power cable is currently undergoing destruct ive and nondestructive laboratory testing. Thls cable has the potential for eliminating brine intrusion into the power dellvery system through the use of a hermetically-sealed cable from the surface to the downhole motors.
PROOF OF BINARY CONCEPT IN LARCE SCALE PLANT

Al1 of the more promising binary technologies developed through nearly a decade of R\&D - - and some specifically designed for the plant -- are incorporated in the 45 MWe proof-ofconcept binary plant at Heber. The turbine roll at the plant is expected in the spring of 1985, and construction is reported on schedule and within budget. The plant will be the largest of its kind anywhere in the world, and is designed to establish the economics and prove the operational viability of binary cycle technology. It is expected that the Information obtalned will be transferable to a wide range of moderate-temperature, low-salinity hydrothermal reservoirs. (EDITOR'S NOTE: The plant was completed and began operat1on in June 1985.)

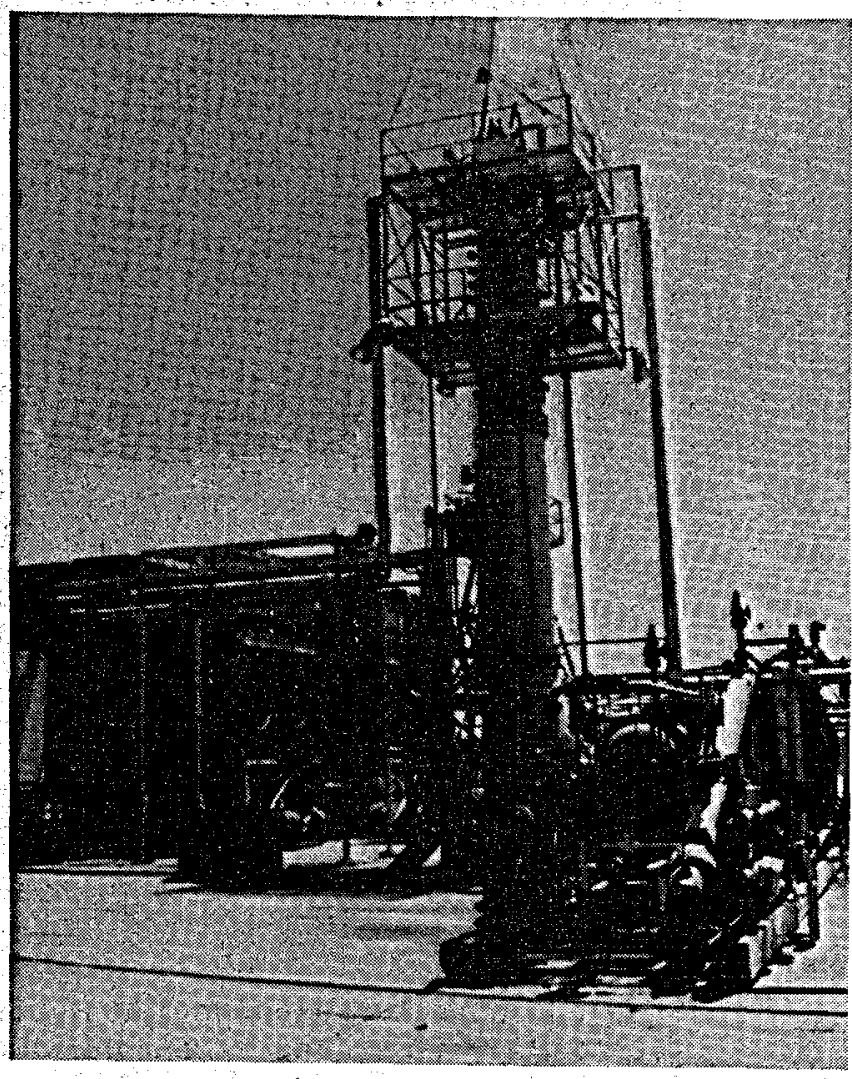

Heat Cycle Research Facllity, currently located at the GTF. 
Funding for the plant was provided primarily by San Diego Gas and Electric Co., manager of the project, and DOE, although contributions have also been made by the Electric Power Research Institute (EPRI), the State of California, the State's Department of Water Resources, the Imperial Irrigation District, and Southern California Edison. EPRI and SCE, along with DOE, are non-owner participants.

The plant will use a supercrit1cal Rankine cycle with a 90-10 mixture of isobutane and isopentane as the initial working fluid. The shelland-tube heat exchangers and condensers are the major capital-intensive components, representing about 30 percent of the total investment in plant construction. As the result of an extensive cost reduction study, major economies were effected.

SDG\&E's contract with Union 011 Co. of California and Chevron Resources Co. features a phased approach to the development of the geothermal reservoir. The initial geofluid delivery, which will be sufficient to permit filling and check-out of the in-plant brine handling equipment, will be periodically Increased to full load requirements in early 1986 if the plant and fluid production are operating as expected.

A major uncertainty has surrounded the spectfications for a hydrocar-

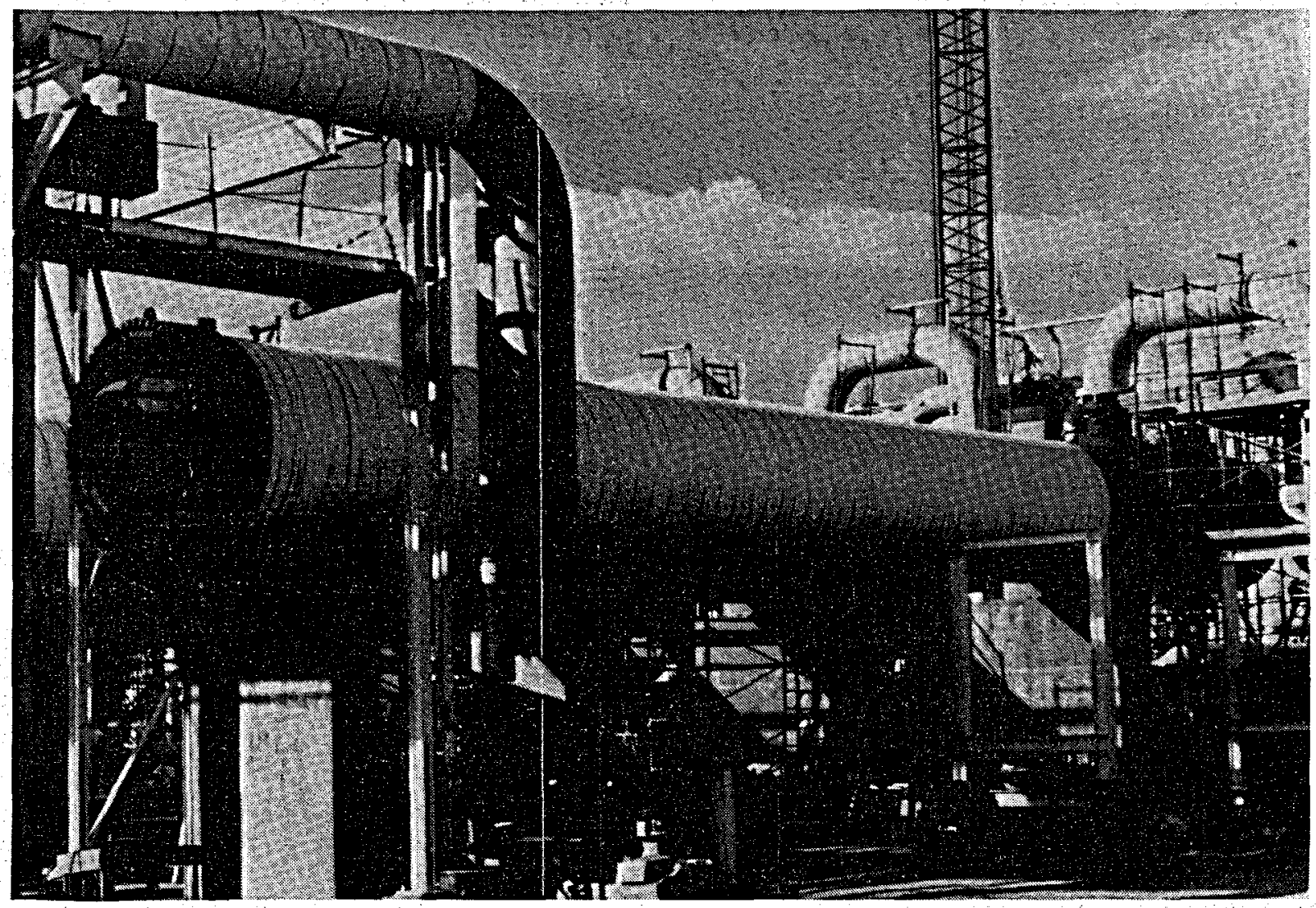

Shell and tube heat exchanger at Heber 46 MWe binary plant. Elght of these 160-ton, 27-meter-long by 2-meter diameter devices are used to transfer geothermal heat to an organic working fluld. Tubes are made of high chromium ferritic stainless steel to minimize corrosion and scaling. 
bon turbine due to the lack of existIng machines of similar size. A four-stage, $3600 \mathrm{RPM}$, double flow, axial turbine was purchased from the Elliott Company, a division of United Technologies, which w111 provide a net plant output of about 45 MWe with a gross rated output of $70 \mathrm{MWe}$. An Electric Machinery Co. generator with brushless excitation will be used with 1 t.

\section{DEVELOPMENTS IN DIRECT USE TECHNOLOGIES}

In 1978, DOE created the Project Opportunity Notice (PON) program to stimulate direct use of low temperature - less than $93^{\circ} \mathrm{C}\left(200^{\circ} \mathrm{F}\right)-$ hydrothermal resources. Since projects of this type were unable to obtain private financing due to the immaturity of the technology, the PON program was designed to provide federal cost-sharing with the private sector. Twenty-three projects were selected to serve as field experiments to demonstrate the technical and economic feasibility of direct heat systems.

The program produced five successful district heating systems in Bolse, Idaho; Elko, Nevada; Klamath Falls, Oregon; Pagosa Springs, Colorado; and Susanville, California. All of them have been, or will be, expanded since DOE participation ended. Two other proposed district heating systems -- in Roxbury, Idaho, and Monroe City, Utah -- were not realized due to an inadequate resource. Another

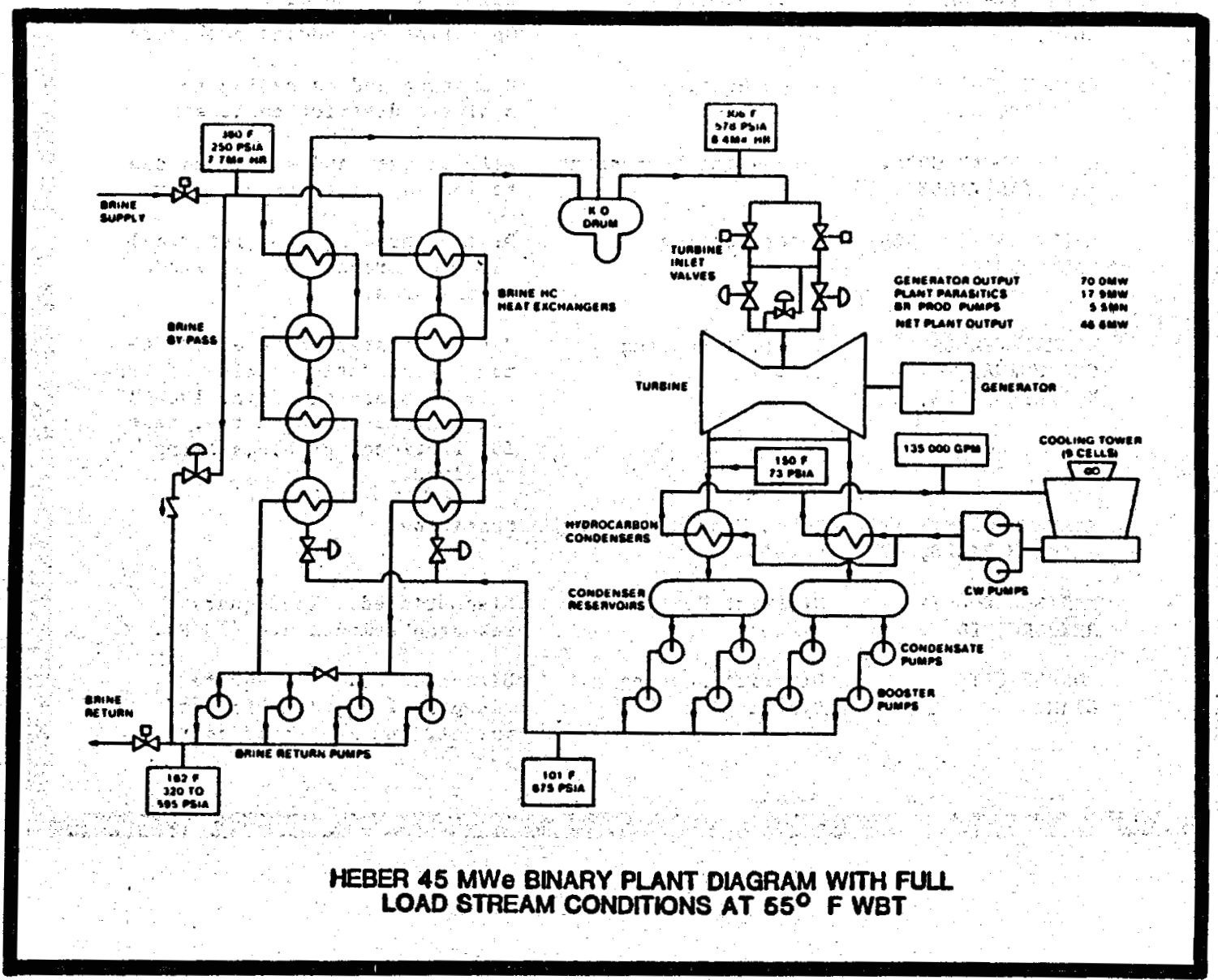


DOE DIRECT USE FIELD EXPERIMENTS

(Cost-Shared with Private Sector)

\begin{tabular}{|c|c|c|}
\hline PROJECT/LOCATION & USE & STATUS \\
\hline $\begin{array}{l}\text { AQUAFRRMS } \\
\text { COACHELIA, CA } \\
\qquad\end{array}$ & Aquaculture & $\begin{array}{l}\text { Supplying heated water for } 50 \\
\text { acres of ponds fliled with } \\
\text { prawns, catflsh, carp, and } \\
\text { Japanese kol. }\end{array}$ \\
\hline $\begin{array}{l}\text { BOISE "GEOTHERHAL } \\
\text { BOISE," IDAHO }\end{array}$ & $\begin{array}{l}\text { District Heating } \\
\text { System }\end{array}$ & $\begin{array}{l}\text { C1ty system. Operating and } \\
\text { Adding Customers. }\end{array}$ \\
\hline $\begin{array}{l}\text { DIAMOUD RING RANCH } \\
\text { RAAROG COUNTY, SD }\end{array}$ & $\begin{array}{l}\text { Space Heating; } \\
\text { Agriculture }\end{array}$ & $\begin{array}{l}\text { Was operated, but unused while } \\
\text { ranch for sale and unoccupled. }\end{array}$ \\
\hline $\begin{array}{l}\text { DOUGHAS HIGH SCHOOL } \\
\text { BOX ELDER, SD }\end{array}$ & Space Heating & $\begin{array}{l}\text { Discontinued when school could } \\
\text { not provide well. Drilling } \\
\text { fallure. }\end{array}$ \\
\hline $\begin{array}{l}\text { EL CENTRO COMMUNITY } \\
\text { CENTER } \\
\text { EL CENTRO, CA } \\
\end{array}$ & $\begin{array}{l}\text { Space Heating \& } \\
\text { Cooling; Domestic } \\
\text { Hot Water }\end{array}$ & $\begin{array}{l}\text { Wells needed rework. No } \\
\text { additional funds avallable from } \\
\text { city. Wells plugged and } \\
\text { abandoned. Site restored. }\end{array}$ \\
\hline $\begin{array}{l}\text { ELRO HEAT CO. } \\
\text { ELKO, NV }\end{array}$ & $\begin{array}{l}\text { District Heating } \\
\text { System }\end{array}$ & $\begin{array}{l}\text { Privately-owned company. } \\
\text { Operating and adding customers. }\end{array}$ \\
\hline $\begin{array}{l}\text { BAAKON SCHOOL } \\
\text { PHILLIP, SD }\end{array}$ & Space HeatIng & $\begin{array}{l}\text { Operating and cascading to } \\
\text { business district customers. }\end{array}$ \\
\hline $\begin{array}{l}\text { HOLLY SUGAR CORP. } \\
\text { IMPERIAL VALLEY, CA }\end{array}$ & Industrlal Process1ng & $\begin{array}{l}\text { Well plugged and abandoned due } \\
\text { to Inadequate reservolr flow. }\end{array}$ \\
\hline $\begin{array}{l}\text { KELLY HOT SPRINGS } \\
\text { CALIFORNIA }\end{array}$ & Space HeatIng & $\begin{array}{l}\text { Discontinued due to historical } \\
\text { value of archaeological finds } \\
\text { in the area. }\end{array}$ \\
\hline $\begin{array}{l}\text { KLAMATH FALLS } \\
\text { GEOTHERMAL } \\
\text { KLAMATH FALLS, OR }\end{array}$ & $\begin{array}{l}\text { District Heating } \\
\text { System }\end{array}$ & $\begin{array}{l}\text { Part of system operated for } 4- \\
\text { month test during spring of } 1984 \text {. } \\
\text { Will be operated during } 1984-85 \\
\text { heating season as further test. } \\
\text { Institutional problems being } \\
\text { resolved. }\end{array}$ \\
\hline $\begin{array}{l}\text { RLAMATH COUNTY YMCA } \\
\text { RLAMATH FALLS, OR }\end{array}$ & $\begin{array}{l}\text { Space Heating; Water } \\
\text { Heating }\end{array}$ & Operating. \\
\hline $\begin{array}{l}\text { MADISON COUNTY } \\
\text { REXBURG, ID }\end{array}$ & $\begin{array}{l}\text { District Heating } \\
\text { Systew }\end{array}$ & $\begin{array}{l}\text { Discontinued. Inadequate } \\
\text { resource temperature }\left(70^{\circ} \mathrm{F}\right) \text {. }\end{array}$ \\
\hline $\begin{array}{l}\text { MONROE CITY } \\
\text { UTAH }\end{array}$ & $\begin{array}{l}\text { District Heat1ng } \\
\text { system }\end{array}$ & $\begin{array}{l}\text { Discontinued. Inadequate } \\
\text { resource, flow, deteriorated } \\
\text { warket, and Increased cost. }\end{array}$ \\
\hline
\end{tabular}


DOE DIRECT USE TIELD EXPERIMENTS (COntinued)

(Cost-Shared with Private Sector)

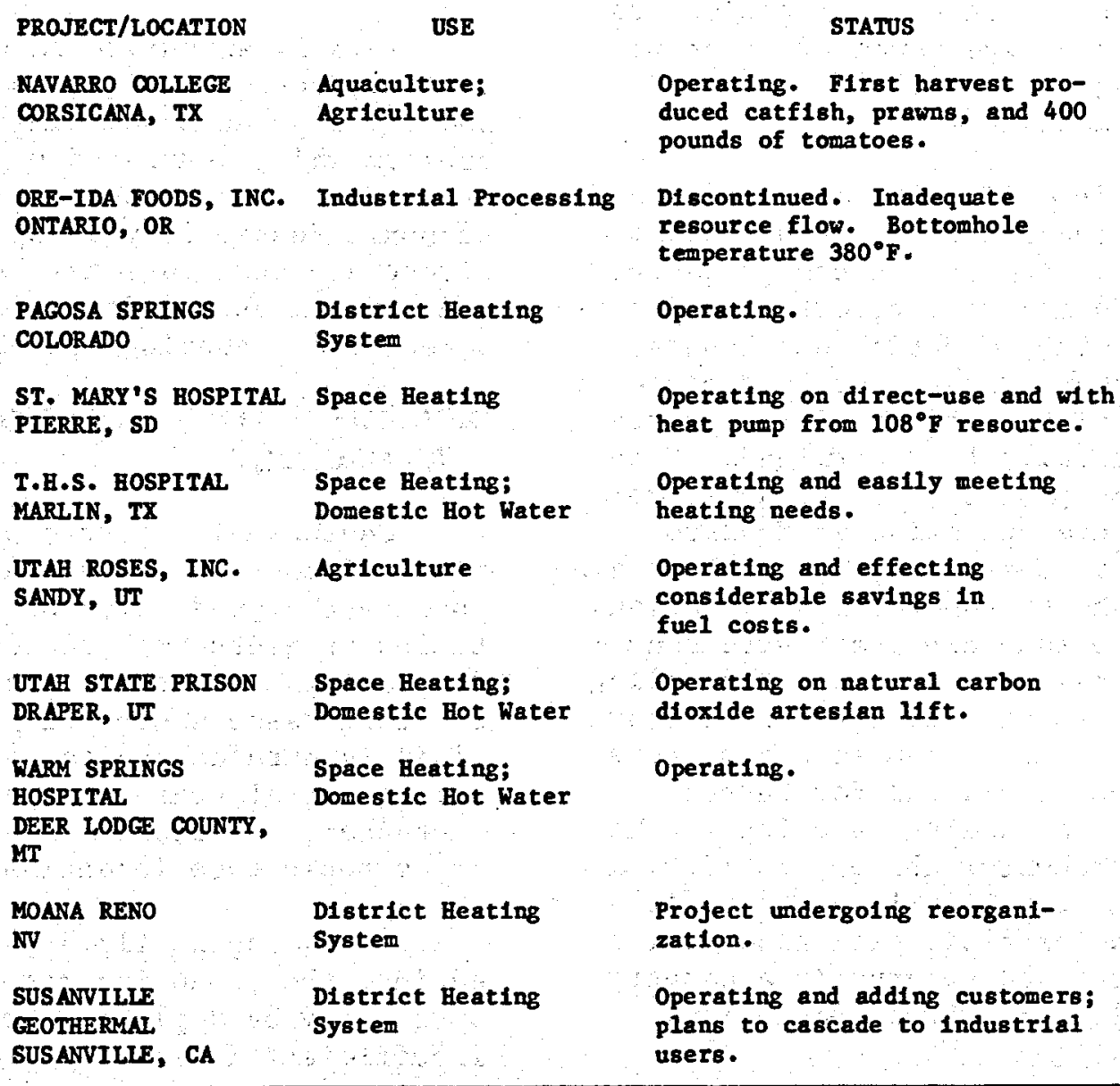

system - In the Moana area of Reno, Nevada - has been delayed due to contractual difficulties, but is expected to be successful in the future.

Six successful institutional. space heating projects resulted from the PON program, serving a school, YWCA, prison, and hospitals. Only two projects of this type failed due to drtlling fallures, one was only marginally operable, and one was cancelled due to archeological finds in the area.

A large commercial greenhouse, a 50-acre aquaculture project, and a cascade application to combine agriculture and aquaculture round out the achievements of the PON program. One vegetable processing application failed due to inadequate resource flow.

The completion rate of the projects of almost 70 percent is significantly higher than the national average for geothermal well completions -47 and 22 percent respectively in 1980 and 1981. According to DOE project managers, the success rate of the PON projects is the result of these factors:

- completion selection of only the most promising projects

- selection criteria for the projects (resource, project team, application, and economics) 
- technical assistance provided by DOE's Field Operation offices

- exposure of each project to the experience of other projects at project review meetings.

It is difficult to assess the overall success of the PON program in stimulating direct use projects. DOE fleld managers report considerable contact with potential developers, but whether privately-funded projects are the direct result of the program cannot usually be determined. However, one project, the aquaculture/ agriculture operation at Navarro College in Corsicana, Texas, is spawnIng of fshoot commercial applications. While the two-acre prawn-greenhousecatfish cascade system at the college was not designed to pay back 1 ts own costs, a simflar 250-acre commercial operation is planned for Burnes, Oregon, and funding is being sought for a freshwater shrimp, catfish, and crayfish operation in southern Arkansas. The geofluid will also heat a greenhouse and eventually a cannery In the latter 3000-acre complex.

Subsequent to the PON program, DOE entered a cooperative agreement with the state of New York and state utilities to provide partial funding for a geothermal heating system for two schools in Auburn, New York. Th1s system, which is still under construction, is the first direct use of geothermal energy in the Northeast. Other communities in the area are watching development of this project with considerable interest.

In order to further stimulate interest in direct applications of geothermal energy, DOE has awarded a technology transfer contract to the Geo-Heat Center at the Oregon Inst1tute of Technology. It is working wth potential users, consultants, Industry organizations, engineers, and state energy offices upon request to provide direct technical/economlc feasibility analysis for those actively Involved in geothermal development.

This is an outgrowth of DOE's earlier Geothermal Program Research and Development Announcement (PRDA) program which consisted of a number of studies of the engineering and economic feasibility of specific direct use applications. A large body of valuable information on direct use technologies resulted.

\section{DEVELOPMENTS IN INJECTION TECHNOLOGY}

Geothermal electric power production and most direct use applications involve the production of large quantities of geothermal fluids. Surface disposal is only theoretically possible in cases where the geothermal fluld Is pure enough to avold adverse envi ronmental consequences. In other Instances, the fluid must be disposed of by subsurface injection.

If the spent fluid is not injected Into the producing reservolr, the system may be depleted, resulting in insufficient fluids for production, subsidence, or both. While injection into the producing reservoir will recharge the system, short-circuiting of the fluid to the production zone before sufficient heat is transferred to it from the formation must be avolded. The resulting production temperature decline could be disastrous for the energy conversion process.

These problems have been studied extensively since the inception of the federal geothermal program. Mathematical modeling, primarily at Lawrence Berkeley Laboratory and Stanford University, has been used to attempt to understand flow and heat transfer mechanisms in geothermal reservolrs. The use of tracers in reservoirs has been valuable in understanding the 
behavior of injected fluid. Much R\&D has been devoted to tracer studies, resulting in improved tracing agents and $a$ better understanding of the tracer/formation interaction. Injection/backflow (or "huff-puff") tests, performed by the University of Utah Research Institute and the Idaho National Engineering Laboratory, have yielded information on injection behavior using individual wells and plants and injection systems. The reactor-clarifier treatment system used at the GLEF has removed some of the barriers to development in the highly saline areas in the Imperial Valley. Plants currently under construction near Niland are using modifications of the technology developed at the GLEF.

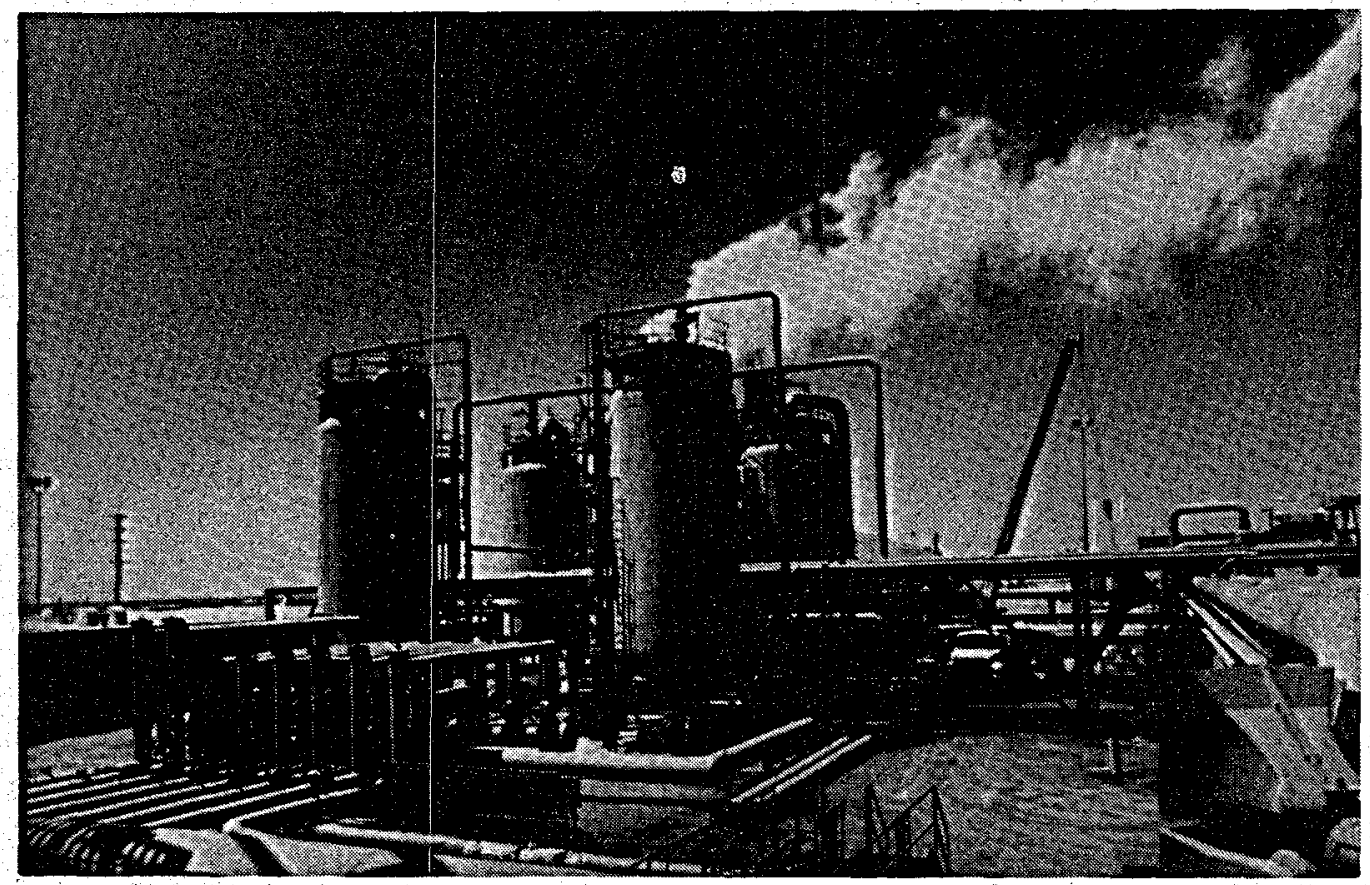

Vertical crystallizer tanks of a flash steam plant near the Salton Sea. This technology was developed at the GLEF specifically to tap the Salton Sea reservoir's very desirable high temperature and 3,000 to 4,000 MWe electric generation potentlal. The crystallizer/clarifier concept will be used at many other high salinity sltes. Courtesy of Gosin Birmingham, Inc.

short-term tests. This avolds the high cost and extremely long duration of borehole to borehole experiments.

The other major problem in brine injection is the precipitation of scale from the brine which, in an Injection we11, will block the flow paths and require either expensive workovers or the drilling of a new we11. The Geothermal Loop Experimental Facility provided the opportunity to Identify problems in working with highly saline brine and to develop solutions for both electric power
Experiments have shown that suspended solids are not constant from a given well, varying from day to day and even hour to hour. In order to obtain useful information on brine chemistry, DOE is supporting R\&D at Battelle Pacific Northwest Laboratorles for continuous monitoring instrumentation of suspended solids in the brine as well as other on-1ine control instruments. 


\section{IMPROVEMENTS IN ENVIRONMENTAL CONTROL}

The type, severity, and acceptability of enviromental impacts from geothermal development are very sitespecific, depending on the geothermal fluid characteristics; the topographic, geologic, hydrologic, and tectonic features of the site; other development in the area; the pre-existing quality of the environment; and the type of geothermal utilization system. Potential environmental problems and effective control technologies of geothermal energy utilization are identified in the following table.

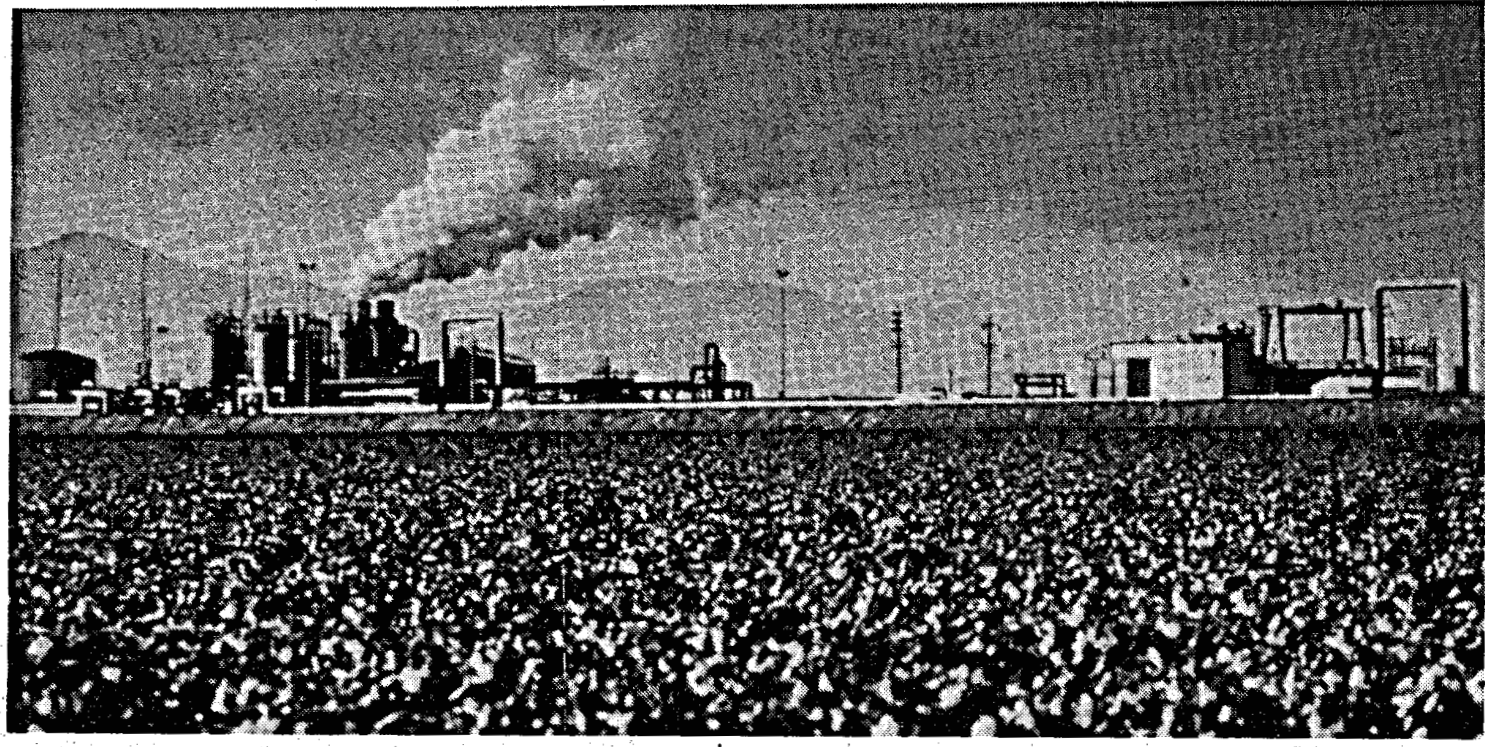

Irrigated flelds grow up to boundry of $10 \mathrm{MWe}$ Salton Sea geothermal flash plant. The onset of geothermal development in the Imperlal Valley created much concern about the potentlal adverse effects it might have on the Valley's egricultural economy. Many local organizations, government agencies, and individuals partlcipated in the flve-year Imperial Valley Environmental Project, Initlated in 1975 and funded by a predecessor to the Department of Energy. The project developed the Impartial Information needed to guide geothermal development in the area and prevent damage to the Valley's ecology or economy. 
POTENTIAL ENVIRONMENTAL PROBLEMS IN GEOTHERMAL DEVELOPMENT AND EFFECTIVE SOLUTIONS

\section{PROBLEM \\ SOURCE/CAUSE}

Atr emisions

$\mathrm{H}_{2} \mathrm{~S}$ entssions from The Geysers production areas and power plants

- Spent geothermal brine

Liquid

discharges

\section{ABATEMENT/CONTROL/DISPOSAL} METHODS

\section{STATUS}

- Stretford scrubbing Process

- Dow RT-2 Technology Process

- Bechtel Upstream Boller

- H2S control methods developed and tested by DOB

- EIC Copper Sulfate System

- voP Catalytic Oxidation Process

- Sheinbaum Direct Chlorination Process

- Research Cottre11/Ion Physics E-Beam

- Usually subsurface injection

- Coollng water

- Liquids from alr pollution abatement and solld waste treationt

- Prior surface treatment if needed

- Surface discharge of uncontaminated fluid when sultable water body 18 avallable
Most commonly used in recent years

Bxisting plants at The Geysers being retrofitted with process - reduced cost and no need for toxtc waste disposal

New technology as yet untried commercially

Not econonical

Successful test

Econonically competitive with other processes

Mixed result:

Injection technology available, Improvements In economics and enviromental acceptability needed

- Spills 
POTENTIAL ENVIROMMENTAL PROBLEMS IN GOTHERMAL DEVELOPMENT, Continued

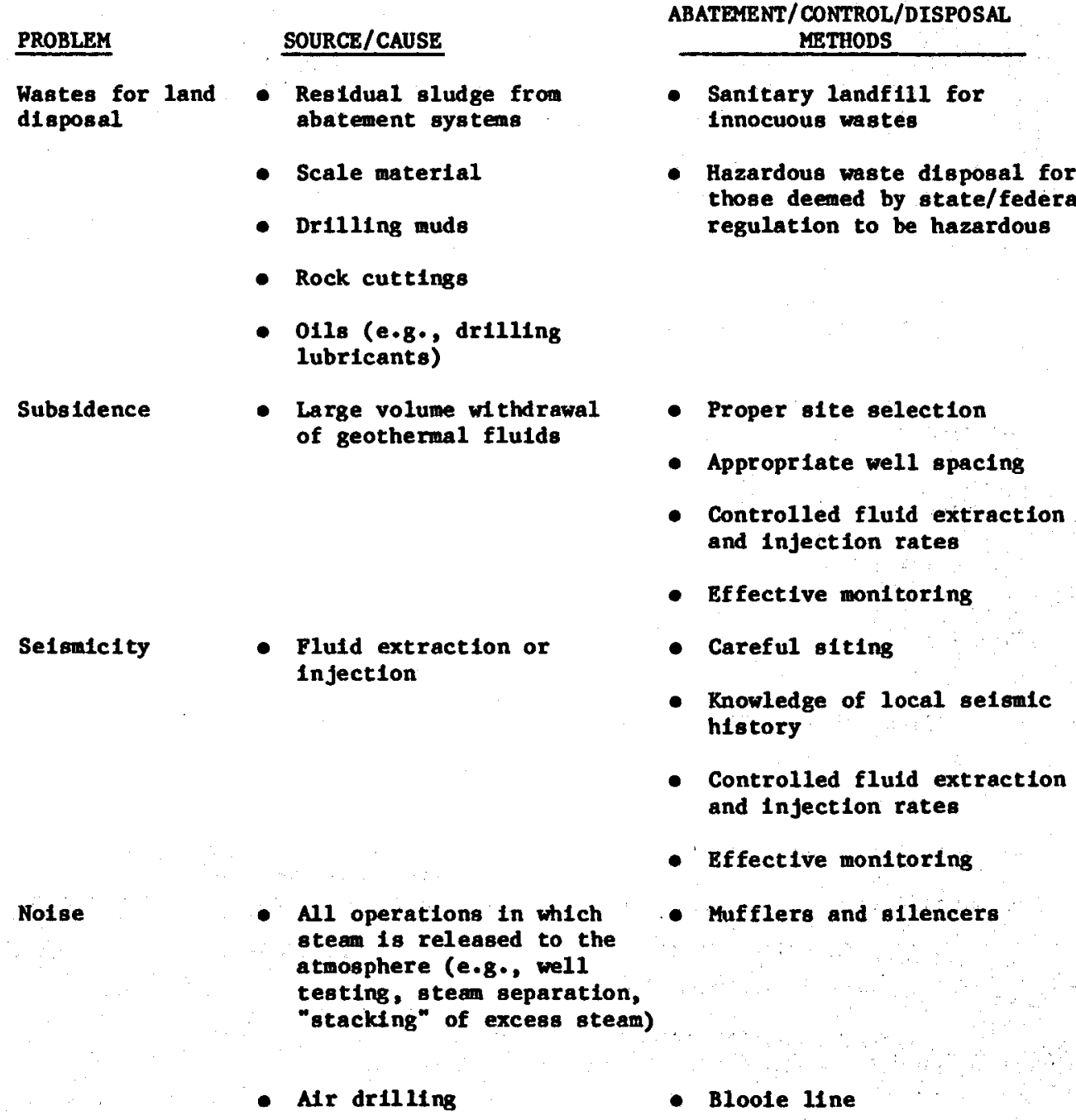

STATUS

Techniques appear to be effective

Techniques appear to be effective

Equipment 18 meeting nolse requirements at The Geysers 


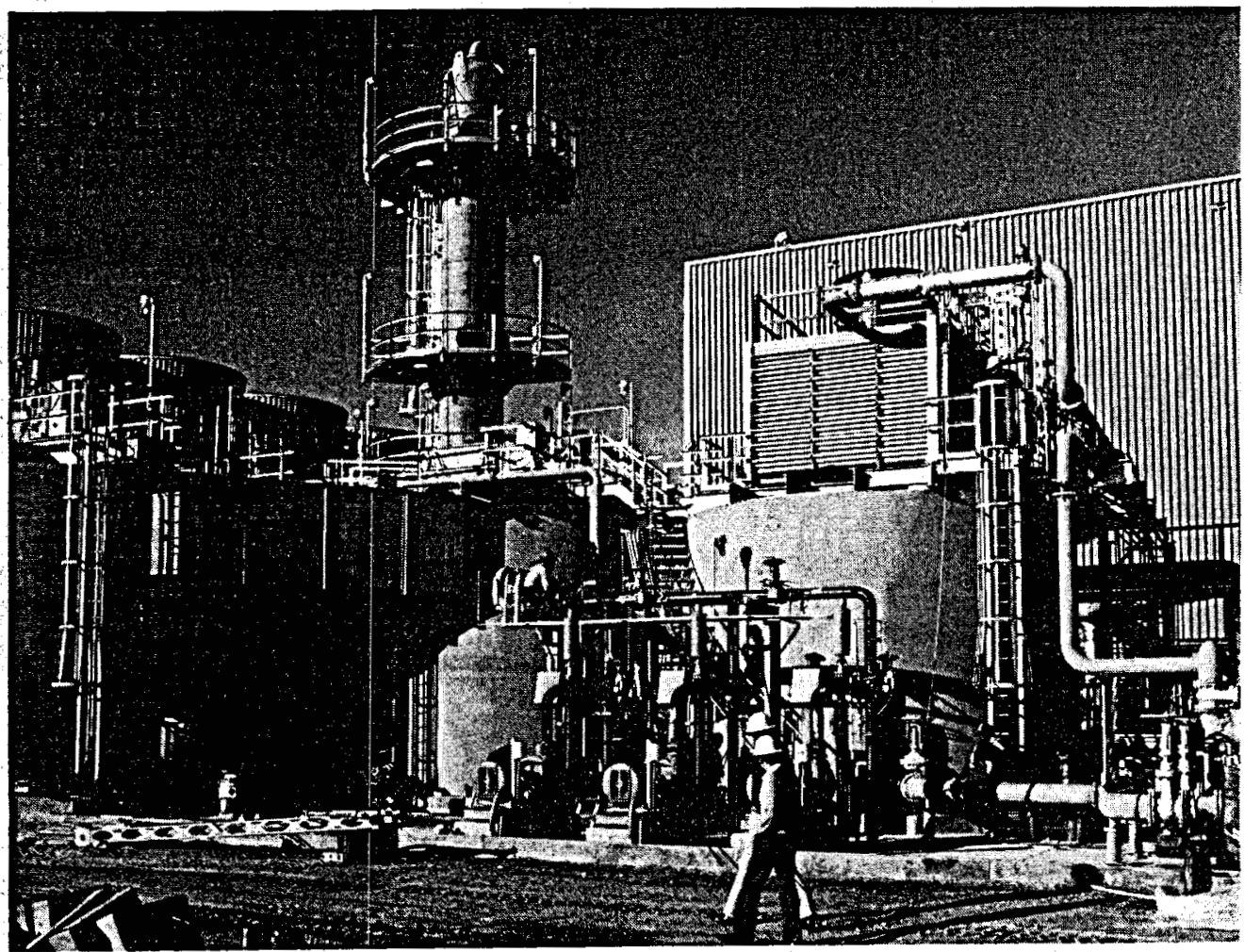

A Stretford $\mathrm{H}_{2} \mathrm{~S}$ emission control system on PG\&E Unit 16 at The Geysers Courtesy of Pacific Gas and Electric Co.

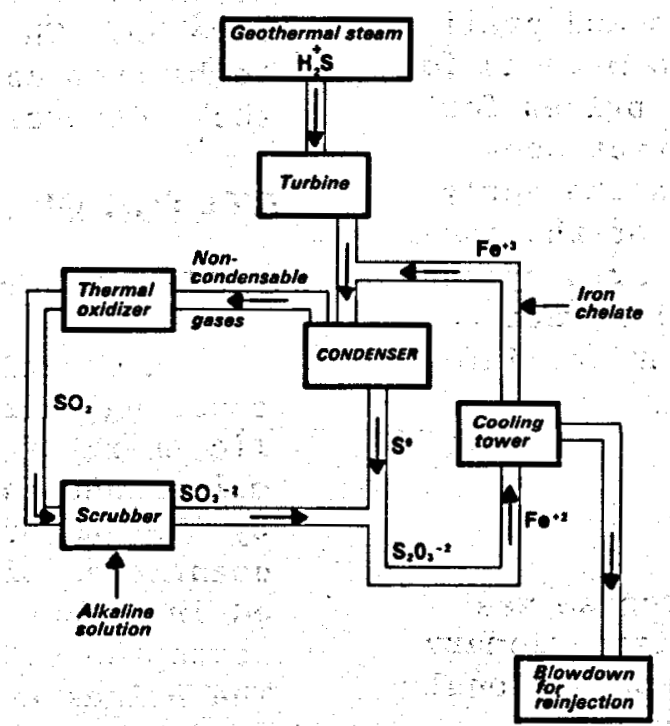

Dow RT-2 $\mathrm{H}_{2} \mathrm{~S}$ abatement system in use at The Geysers. The process converts the gas to a soluble sulfur compound that is injected back into the formation, and produces no toxic wastes. Courtesy of Dow Chemical Co. 


\title{
PROGRESS IN EXPERIMENTAL GEOTHERMAL TECHNOLOGIES
}

\author{
STATUS IN 1974
}

\section{GEOPRESSURED}

The federal geopressured geothermal R\&D program began in 1974. It was inftiated to determine whether the geopressured brine aquifers of the U.S. Gulf Coast could be exploited as a major domestic source of energy. As estimated by the USGS, these aquifers contain 170,000 quads of methane and thermal energy. In addition, the high pressure of the brines also provides opportunities for utilizing their hydraulic energy. By comparison, U.S. energy consumption is about 75 quads per year.

The Initial research was Iimited to geological studies of the Gulf Coast sedimentary basins and preliminary investigations into methods for using the energy in the brines for power generation and direct uses. However, the program was the early beneficiary of the logs of thousands of wells drilled in the area by the ofl and gas industry which were to provide invaluable subsurface information.

\section{HOT DRY ROCK}

The hot dry rock program was launched in 1971 with discretionary funding for the Los Alamos National Laboratory where the concept of extracting heat from hot dry rock was developed in 1970. By 1974, two exploratory holes had been drilled at the Fenton H111, New Mexico, experimental site that confirmed its two basic principles. In this concept, fluid is circulated through a man-made fracture between two wells, absorbing the heat of the rock. The nation's hot dry rock resources are estimated to contain nearly 500,000 quads of energy.

\section{MAGMA}

While the potential of magma as an alternative source of energy had been recognized for some years, it was not until mid-1973 that Sandia National Laboratories proposed active investigation. In 1974, a Conference on the Utilization of Volcano Energy was sponsored by the Japanese and the National Science Foundation at Hilo, Hawai1. This conference attracted international attention to the concept of magma energy use, and an Increased level of sclentific interest began to develop. This resource is estimated to be even larger than the hot dry rock resource.

\section{STATUS IN 1984}

\section{GEOPRESSURED}

A practical technology for recovering thermal, chemical, and hydrau1ic energy from geopressured geothermal brines is likely to be avallable by the end of this decade. Very large quantities of these brines are contained in porous sandstone formations beneath the U.S. Gulf of Mexico Coast. The brines are hot $120-205^{\circ} \mathrm{C}(250-$ $400^{\circ} \mathrm{F}$ ), contained at abnormally high pressures (typically thousands of pounds per square inch at the wellhead), and saturated with dissolved natural gas (twenty or more cubic feet of methane per barrel of brine).

The geopressured geothermal research program inftiated and carried out by DOE and its predecessor agencies in the past ten years has estab- 
11shed that:

- The quantity of methane contained in this resource is large - - the U.S. Geological Survey estimates 5700 quads in the sands tone reservoirs. The quantity of thermal energy in place is larger.

- It is posstble to find such reservoirs as drilling targets, using geophysical logs from previously drilled wells and active seismic data.

- It Is possible to adapt U.S. petroleum industry drilling and production technology to the production of geopressured brines.

- It Is possible to extract most of the methane from the brine by a simple and economical gravity separation technique.

- It is possible to dispose of the spent brine by injecting it into empty geologic formations at relatively shallow depths.

This information has come from extensive field and laboratory research. First, the basic reservolr properties were inferred by analysis of the geophysical logs from thousands of wells drilled by industry in the search for conventional o1l and gas resources. Then brine production tests of a few weeks duration were run In several of the industry-dri11ed wells at diverse locations. Finally, four especially destgned DOE wells were drilled for long-term brine production tests at high rates. Reservolr "stress tests" have been completed in some of these wells and are underway in others. The recent successful trial of an experimental scale control technique has opened the door for flow tests at potentially commercial flow rates.
In the laboratory, samples of reservolr rocks and fluids are subjected to temperature and pressure conditions that mimic those in the reservoirs. The response of samples to changes that simulate production conditions (reduction of pore fluid pressure) reveal how actual reservoirs behave. Mathematical descriptions of that response then are used in computer codes developed to model reservoir behavior and thus to predict reservoir performance.

Field operations have shown that the environmental impact of geopressured geothermal well operations is likely to be benign, except that the possibility for land surface subsidence remains uncertain. Measurements of selsmic activity around geopressured geothermal production wells, some downhole measurements, active selsmic work, and perlodic land surface leveling are employed to evaluate the subsidence question.

In addition to hot brine and methane, the geopressured geothermal reservolrs produce small amounts of heavier organic compounds. These are sampled and analyzed to determine their role in the complex and dynamic system of geopressured geothermal reservoir behavior.

Field operations with the DOE wells designed for long-term testing have revealed calcium carbonate scaling to be a major problem. The scaling occurs when the pressure of the brine Is reduced to below a threshold value. Within a few days, scale deposits can severely restrict brine flow in a well. The tendency of a brine to precipitate scale can be controlled by very small concentrations of chemicals called scale inhtb1tors. In a recent experiment at the DOE Gladys McCall well In Loulsiana, an inhibitor solution was forced down the well and out into the geologic formation containing the brine. The theory was that some of the inhibitor 


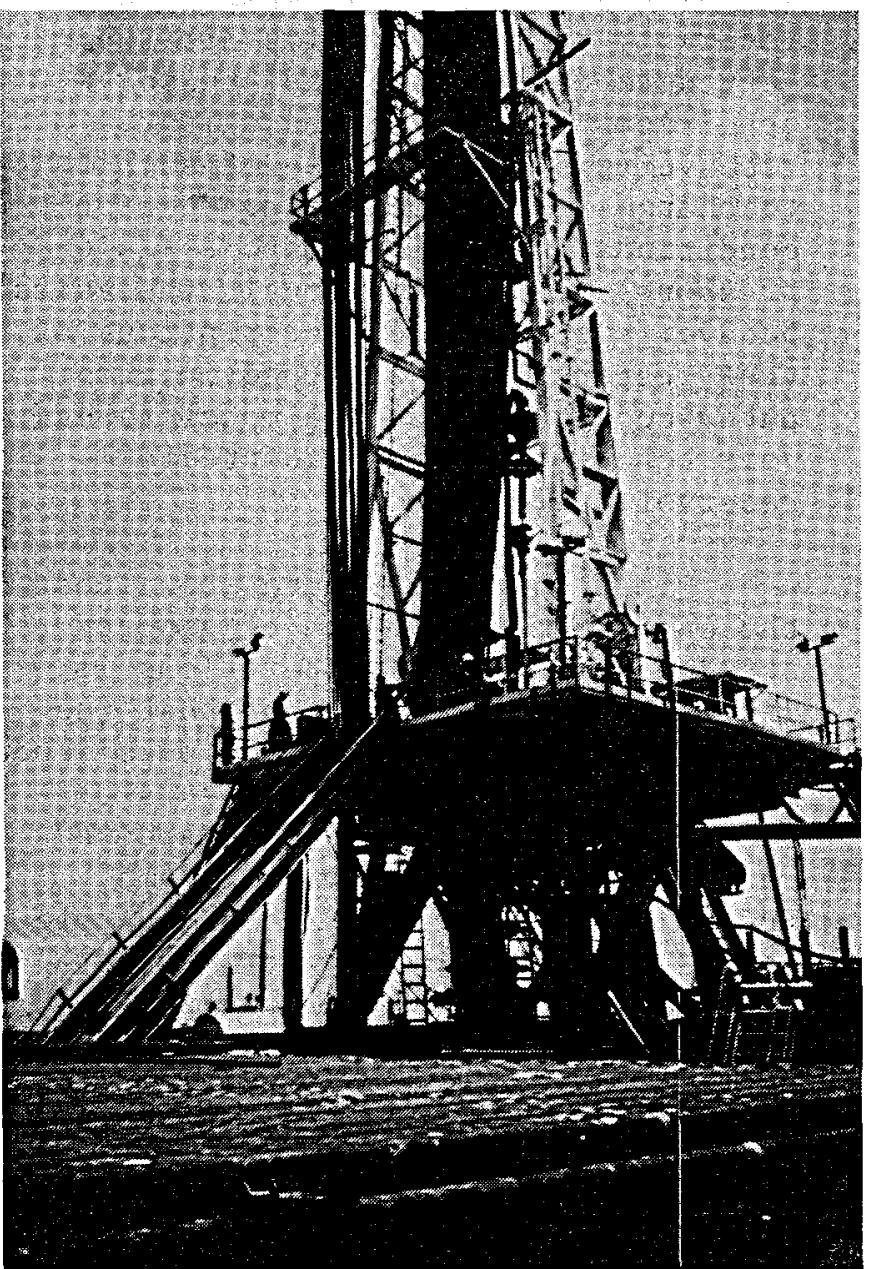

Drilling of the Gladys McCall geopressured well in Cameron Parish, Loulsiana, In 1981. Current production rate being achieved during long-term flow test is 30,000 barrels of brine per day.

would adhere to rock and be released gradually as brine was produced. The subsequent performance of the well seems to support the theory. In 90 days after treatment, the well produced at up to $31,000 \mathrm{bbl} / \mathrm{day}$ with no sign of scaling.

Future plans include DOE cooperation with industry in an experimental program to test advanced technologies for electric power from the heat contained in geopressured geothermal brines. The tests will be carried out with brine and gas from one of the DOE geopressured test wells. The Electric Power Research Institute (EPRI) is representing industry in the conduct of the experiments.
HOT DRY ROCK

1984 found the hot dry rock experiment at Fenton H1ll on the threshold of tests to determine whether an industrial-scale artificial reservoir can be created and operated economically to supply sufficient energy for commercial power generation. It has already been proven by experiments completed in 1981 that energy can be extracted from this source at rates capable of small-scale power production - up to 5 thermal megawatts. If the initial system had been located near a populus area during successful short-term tests, the power produced could have heated several hundred homes.

A new, and much larger than expected, reservoir was created at the end of 1983 by large volume flow pumping of 5.7 million gallons of water under high pressure into the rock. The new reservolr's capacity is estimated at 50 to 150 thermal megawatts, although only $35 \mathrm{MW}$ had been predicted. However, the underground loop needed to Inject and recover fluids was not completed in this operation, and current ef forts center on intercepting the new reservolr. Once this is accomplished and a continuous loop is established, long-term heat extraction experiments will be performed. (EDITOR'S NOTE: The interception was successfully completed in May 1985.)

The Los Alamos NatIonal Laboratory scientific and engineering support team for Fenton Hill performs such functions as reservoir engineering, instrument calibration and maintenance, reservolr size assessments, and geochemical studies. A unIque support function completed this year was the development of a serles of "slim line" tools needed to fit in the small diameter - $4-1 / 2$ inch - wells used in the project. The components of all of the tools developed, Including electronic 


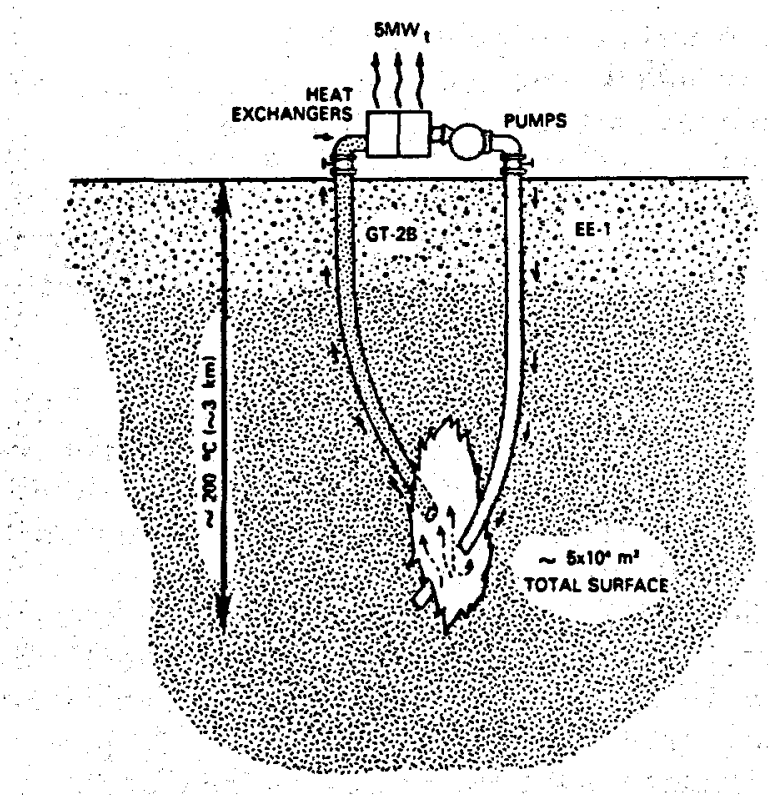

Phase I, 6 MW t hot dry rock experiment.

devices, are constructed of materials that will withstand the high downhole temperatures of the final system -about $325^{\circ} \mathrm{C}\left(648^{\circ} \mathrm{F}\right)$ at 14.400 feet.

\section{MAGMA}

In only 10 years after interest in the concept of extracting heat from magma sources began to develop, the scientific feasibility of doing so has been demonstrated. DOE is proceeding to test the economic and technological feasibility of utilizing the heat of this resource.

During a DOE-funded seven-year research project conducted by Sandia National Laboratories, experimental boreholes were drilled well into buried molten rock at temperatures up to $1100^{\circ} \mathrm{C}$, and speclally designed downhole heat extraction equipment was successfully demonstrated. The Rilauea Iki crater in the Hawa11 Volcanoes National Park, which was filled with molten lava to a depth of about 400 feet, was used as a field laboratory. Although not a true magma deposit, Sandia reported that the only significant differences between this ponded lava flow and that of a magma body is size, gas content, and depth. Temperatures and other material properties were close enough to real magma to provide a realistic laboratory.

It was concluded that there are no known Insurmountable theoretical or physical barriers that invalidate the concept of extracting heat from magma. Existing geophysical exploration systems are believed capable of locating and defining magma bodies and were demonstrated at Kilauea Ikf. Drilling rigs that can drill to the depths required to tap magma and engineering materials compatible with the buried magma environment are available. Sandia reported that energy can be extracted at attractive rates from magma resources in all petrologic compositions and physical configurations.

\section{GEOTHERMAL R\&D - THE PRESENT AND FUTURE}

The DOE geothermal program is managed by the Department's Geothermal Technology Division (GTD), with the Department's field offices responsible for direct technical project management. The national laboratories serve the program as its main research arm.

The program is divided into two major elements: Geothermal Geosciences Research and Geothermal Conversion Research.

The major thrusts of the hydrothermal R\&D are in response to industry consensus that four factors constitute the remaining technological and economic impediments to development of hydrothermal reservoirs:

- drililng costs

- lack of confidence in reservoir definition 
- uncertain behavior of injected fluids

- capital costs of power plant construction.

The hydrothermal activities addressing these problems can assist industry development in the near future. The other hydrothermal activ1tles are long-range R\&D targeted on increasing the knowledge of hydrothermal reservoirs through developing techniques for defining the large hydrothermal reservoirs in the Cascades Mountains in the Paclfic Northwest and investigating the origins of hydrothermal reservoirs through studles at the Salton Sea Sclentific Drilling Project. (See LEASING AND DRILLING. for detalls.) The balance of the R\&D 1 s designed to prove the feasibility and economics of using geothermal energy other than hydrothermal fluids.

The next step in geopressured geothermal R\&D is experimental power generation, the first with this form of energy anywhere in the world. The experiment is a cooperative effort of DOE and the Electric Power Research Institute. DOE will furnish the well, the Pleasant Bayou, In Brazoria County, Texas, and some of the plant's component parts, and EPRI will assume the balance of the cost to furnish a hybrid generating system. The system will use both a geothermal binary cycle and a gas engine powered by the liberated methane.

Long-term, high-rate flow testIng of two geopressured wells will continue until 1988 to provide sufficlent data to determine the economics of the production and utilization of geopressured brines. If the results are favorable, this resource could become a significant factor in the Gulf Coast energy mix by the $1990^{\prime} \mathrm{s}$.

Drilling has just begun at the hot dry rock experiment site at Fenton Hill, New Mexico, to connect two wells -- one for infection of surface water and one for recovery of heated water -- so that the large reservoir created last year can be used for power generation experiments of commercial-size capacity. (EDITOR'S NOTE: The connection was successful1y completed in May 1985.)

The ultimate goal of the magma energy extraction project is to intercept a magma body with prototype hardware designed to drill to as deep as 10,000 feet at temperatures up to $1000^{\circ} \mathrm{C}\left(1900^{\circ} \mathrm{F}\right)$. Some 20 sites were evaluated, and the Coso and Mono-Long Valley KGRA's in California have been selected for further study. If preliminary systems analysis and cost estimates are encouraging, one of the two sites will be selected for dril1ing, probably around 1990. 
V.S. DEPARTMENT OF ENBRGY GEOTHERMAL PROGRAM

GEOTHERMAL GEOSCIENCE TECHNOLOGY

Hard Rock Penetration Research

\section{Objective}

Develop components and field test an advanced drilling system to reduce well costs by $50 \%$

Activitieg

- Non-Conventional drilling

Pluid Losa Control

- Mechanics of Rock

Penetration

- Borehole Mapping

DOB/Industry Cost-

Shared Drflling

\section{Hydrothermal Reservoir Research}

Develop Improved reser voir understanding and prediction methods to provlde management tools and reduce uncertainty ind reduce uncert in behavior predict
- Reservolr Definition

- Reservolr productivity assessment

- Fracture mapping

- Brine Injection

- Pluid migration

- Monitoring and prediction

- Well completion techniques

- Techniques for defining

Cascades Reservolrs

- Salton Sea Scientific

Drilling Project

- Reservolr Permeability

Bnhancewent

- State Reservotr AsseBsment programs
GEOTHERMAL CONVERSION TECHNOLOGY

Hydrothermal Conversion Research

\section{Objective}

Make significant improvements in conversion sys-

tems for hydrothermal

electric and direct heat uses which can be applied

by - Industry in the near

term.

\section{Activities}

Heat Cycle Research - Improved working fluids

- Improved heat

transfer

- Improved downole pumps

- Geothermal Test Factlity

Brine InjectionSurface Treatment

- Hybrid Binary Tech-

$$
\text { nology }
$$

- Materials/Brine

Chemistry

Direct Heat

Pield Experiment:

\section{Binary Conversion Technology Verification}

Evaluate the operational

viability and establish

the economics of large size

binary cycle electric plants.

- Heber, California 45 me Binary 1 plant

- R\&D Support for plant 
U.S. DE PARTMENT OP ENERGY

GEOTHERMAL PROGRAM, Cont1 nUE

\section{GROTHERMAL GEOSCIENCE TECHNOLOGY}

\section{Geopressured Production Research}

\section{Objective}

Complete 1) the development of predictive

models for geopressured reservolr performance

based on long-term flow

testing, and 2) econoulc

analysis of the total

geopressured energy recovery

system.

\section{Hot Dry Rock Research}

Complete the development of 1) microselsmic ment cechnology for characterizing deep hydraul1 fractures in stressed crystalline rock, and 2) methodology for creation of high surf ace are heat exchanger systems in deep, hot geosystems.
Activities

- Geopressured Design Hell Tests

- Envirommental Monitoring Untversity and Industrial Research

- Hot Dry Rock Energy Bxtraction

- Sclentific and Engineering Support

\section{GEOTHERMAL CONVERSION TECHNOLOGY}

Geopressured Conversion Research
Objective

Determine 1) the efficiency of electric energy conversion that can be obtalned with geopressured brines. and 2) the engineerIng and economic feasibility of direct uses of geopressured brines.

\section{Activities}

- Power Generation Experiment in Cooperation with Blectric Power Research Inst1-

Selected Direct Heat Expertment (B)

\section{Hot Dry Rock Conversion Research}

Determine the economtc feastbility of comberclal use of the recovered heat of hot dry Experiment

- 9000 - Hour electrictity.
Power Generation Experiment 
U.S. DEPARTMENT OF ENERGY

GEOTHERMAL PROGRAM, Continued

GEOTHERMAL GEOSCIENCE TECHNOLOGY

Magaa Energy Extraction Research
GEOTHERMAL CONVERSION TECHNOLOGY

Magma Energy Conversion Research

Converston - oriented R\&D w11 not be undertaken unless the technical and economic feasibility of extract Ing magma energy is favorable.
Identify potentially

the engt-

and decerwine

neering and

- System Integration

- Geophysics

- Geochemistry and Materlals

- Drilling Technology

Energy Ext raction

their heat.

Technology Transfer

- Cost-Shared Projects

- Technical Conferences and Publications

- Toplcal Seminars and Workshops

- Toplcal Seminars and Workshops

- Industry Observation of Prototype Technolog 


\section{TEN YEARS LATER IN GEOTHERMAL LEASING -- 1974-1984}

\section{LEASE ISSUANCE}

The Geothermal Steam Act was enacted on December 24, 1970. It provided the Department of the Interior its first statutory authority to lease federally-owned lands for geothermal exploitation although such lands had been avallable for decades for oil and gas, coal, and other minerals. The major provistons of the Act are listed in brief here for the benefit of newcomers to the geothermal field:

- Lands under the jurisdiction of the Bureau of Land Management (BLM) in Interior and the U.S. Forest Service (Department of Agriculture) may be leased for geothermal purposes, except for designated wilderness areas, national parks, and similarly protected lands. The consent of the Forest Service is required before BLM can issue leases on its lands.

- The amount of acreage that may be held under leases issued to any one person or corporation in any one state is 1imited to 20,480 acres; after 15 years the Secretary of the Interior may administratively increase the maximum to 51,200 acres.

- Areas where the geology, nearby discoveries, competitive interests, or other indicia provide strong evidence that a commercial resource is present must be designated "Known Geothermal Resource Areas" (KGRA's).

- Lands in KGRA's must be leased competitively; non-competitive applications may be filed for leases on other avallable land at any time.

- The primary lease term is 10 years; to qualify for an extension, the lessee must have completed one or more wells producing or capable of producing geothermal resources in commercial quantities and must have a contract for sale of the resources.

- Royalty payments for geothermal resource production on leases are inftially set at between 10 and 15 percent, but can be increased at 20year intervals beginning 20 years after commencement of production by up to one-half of the existing rate to a maximum of 22.5 percent.

- The terms and conditions of a lease may be adjusted at 10-year intervals except for royalty rates as described above.

The Steam Act was the first major programmatic legislation to fall under Interior's jurisdiction subsequent to passage of the National Environmental Policy Act of 1970 (NEPA). As a result, the leasing program got off to an extremely slow start. A massive, multi-volume gener1c Environmental Impact Statement (EIS) was prepared by BLM covering the potential effects of the entire program. As a result of the time spent on that project, the regulations were not forthcoming until January 1974, and the first lease sale was not held until over three years after enactment of the Act. 
The drafters of the regulations exercised extreme caution in meeting NEPA requirements. This strict interpretation of the Act has seriously Impeded geothermal leasing up to the very recent past, and its effects are not entirely dissipated today.

In implementing the regulations, competitive tracts were not of fered for sale and non-competitive leases were not Issued until an environmental review was completed on the acreage Involved. This pre-lease review evaluated the potential effects of ful1 development, from exploration through production and utilization as a "worst case" situation, despite official estimates that 24 out of 25 geothermal leases would never be deve1oped because no commerclally exploitable resource would be found Postulating the end use at this point was, according to one BLM spokesman, "an exercise in futility, wasting the taxpayer's time, dollars, and resources."

By 1978 , the leasing program was moving so sluggishly that the President directed the agencies to streamline the process, and an Interagency Geothermal Streamlining Task Force was funded by DOE to develop remedial measures. A statistical study conducted to support the Task Force conclusions found that nearly eight years after enactment of the Act; only 35 percent of KGRA land available for leasing under Bureau of Land Management jurlsdiction had been of fered for lease sale, and only two percent of that administered by the Forest Service.

At the same time, over 60 percent of the non-competitive applicatlons for BLM land had been pending three years or longer. Over 70 percent of the Forest Service applications fell into the same category, and the percentage would have been much higher except for the large number of applications wh thawn due to the excessive delay.

Through a series of public meetings in the "geothermal" states, the Task Force found that a number of problems were impeding geothermal development on federal lands, but without exception industry pointed to the excessive environmental review - Including repetitive post-lease permit reviews - as the primary culprit. As a result, in January, 1979, the Task Force made 19 recommendations for remedial measures to the Interagency Geothermal Coordinating Council. of the 19, four are provisions in geothermal omnibus legislation that has been pending in Congress for over four years. The remaining recommendations called for administrative or regulatory changes for which amendments to the Geothermal Steam Act were not necessary.

Although few of these have been formally implemented, the Department of the Interior has attempted to meet the objective of perhaps the most important one. This was to separate exploration and development in the environmental review process to expedite exploration while assuring ample environmental protection for developmental activities. BLM first of fered, in 1980, a "phased" lease, but industry showed little interest in leases that did not guarantee that development would be permitted. As a result, and in spite of a number of procedural/conceptual changes during intervening years, phased leasing was discontinued early in 1984. In the meantime, in 1982, the Department declared non-competitive geothermal leases eligible for categorical exclusion from the NEPA process where there will be subsequent NEPA compliance prior to development. Neverthe1ess, fleld of fices have found the exclusion unworkable and have continued preparing environmental assessments that attempt to consider all stages of lease development. 
The Forest Service carried out an experiment in four Oregon forests with leases very similar to the BLM phased lease. Instituted as a cost savings plan -- a spokesman for the agency said hundreds of thousands of dollars had been spent over several years on unneeded enviromental analyses - the Contingent Right Stipulation experiment has now been abandoned.

It would not have applied in any event to areas recommended for wilderness status or in sensitive areas where the Forest Service feels that resource conflicts would limit energy development opportunities. Acreage in these areas, according to a spokesman for the agency, accounts for the remaining backlog of Forest Service geothermal lease applications. Otherwise, the spokesman reported, it is reasonably current in issuing leases.

There are many competing interests among users of the national forests which make mineral decisions very difficult in many cases. It is reported in the TECHNOLOGY TRANSFER section that the Forest Service is holding geothermal workshops for its field personnel in an effort to increase their understanding of these problems.

The Forest Service spokesman stated that leases on Forest Service applications filed today for acreage in forests where the environmental impact statement has been prepared will be issued in about two months -unless they are rejected because the particular acreage applied for is designated as unavailable for leasing for environmental reasons or for procedural reasons requiring rejection. If the EIS has not been done, the spokesman said, it would take about a year to obtain a lease, except in "sensitive areas" which are still subject to considerable controversy.
BLM has essentially finished its environmental assessment and land planning for the geothermal areas of interest. While there may be some variation among BLM state offices, non-competitive leases should be expected to be issued in a timely manner.

Nearly all competitive acreage the surface of which 1 s administered by BLM has been of fered, some several times, and the lack of bids on some tracts after belng offered twice resulted in the declassification of several KGRA's: They include:

Gillard Hot Springs, AZ

Ford Dry Lake, CA

Little Horse Mountain, CA

Lovelady RIdge, CA

Witter Springs, CA

Conda, ID

F1y Ranch Northeast, NV

Gerlach Northeast, NV

Monte Neva Hot Springs, NV

Sa1t Wells Basin, NV

All of these revoked KGRA's except Monte Neva were originally. defined on the basis of "competitive interest," or the overlapping by at least 50 percent of two or more non-competitive lease applications, and not on the basis of geothermal indicia.

As of June 1984, BLM had issued 2365 leases for lands administered by that agency compared with 523 for Forest Service lands. Over half of the total leases issued have been relinquished by the lessee or terminated by BLM, leaving a total of 1393 active leases. Of these, only 30 leases embrace producible wells, three in California, 17 in Nevada, and 10 in Utah. There are 12 producing leases, 11 in California and one In New Mexico.

It can be concluded that progress has been made in the timely 
issuance of geothermal leases, but that it was slow in coming.

\section{LEASE EXTENSION}

As of this year on the 10 th anniversary of the first leases 1ssued, the problem became one of keeping the leases beyond the 10-year primary term. Among the conditions required by the Geothermal steam Act for an additional 40-year term is a contract for the sale of the resource from one or more wells producing or capable of producing the resource. Despite substantial development investment on a number of leases, the developers could not find a market for the resource, due to reduced power demand and a poor economic climate. This situation has been remedied for the present with stopgap legislation to provide for a two-year extension of affected leases. Legislation is expected to be introduced next year by Senator Chic Hecht of Nevada to incorporate the stopgap language in the Steam Act as extension conditions for all leases. Details are provided under LEASING AND DRILLING.

\section{ACREAGE LIMITATION}

As noted above, the amount of acreage that may be held under lease by any one person or corporation in any one state is limited to 20,480 acres. The industry feels that this limitation is unrealistic and uneconomic for exploration purposes, and has tried unsuccessfully for several years to obtain an increase through an amendment to the Steam Act. If this amendment continues to fall of enactment, the Secretary of the Interior is expected to use his administrative authority to increase the Iimitation to 51,200 acres in December of 1985 . 


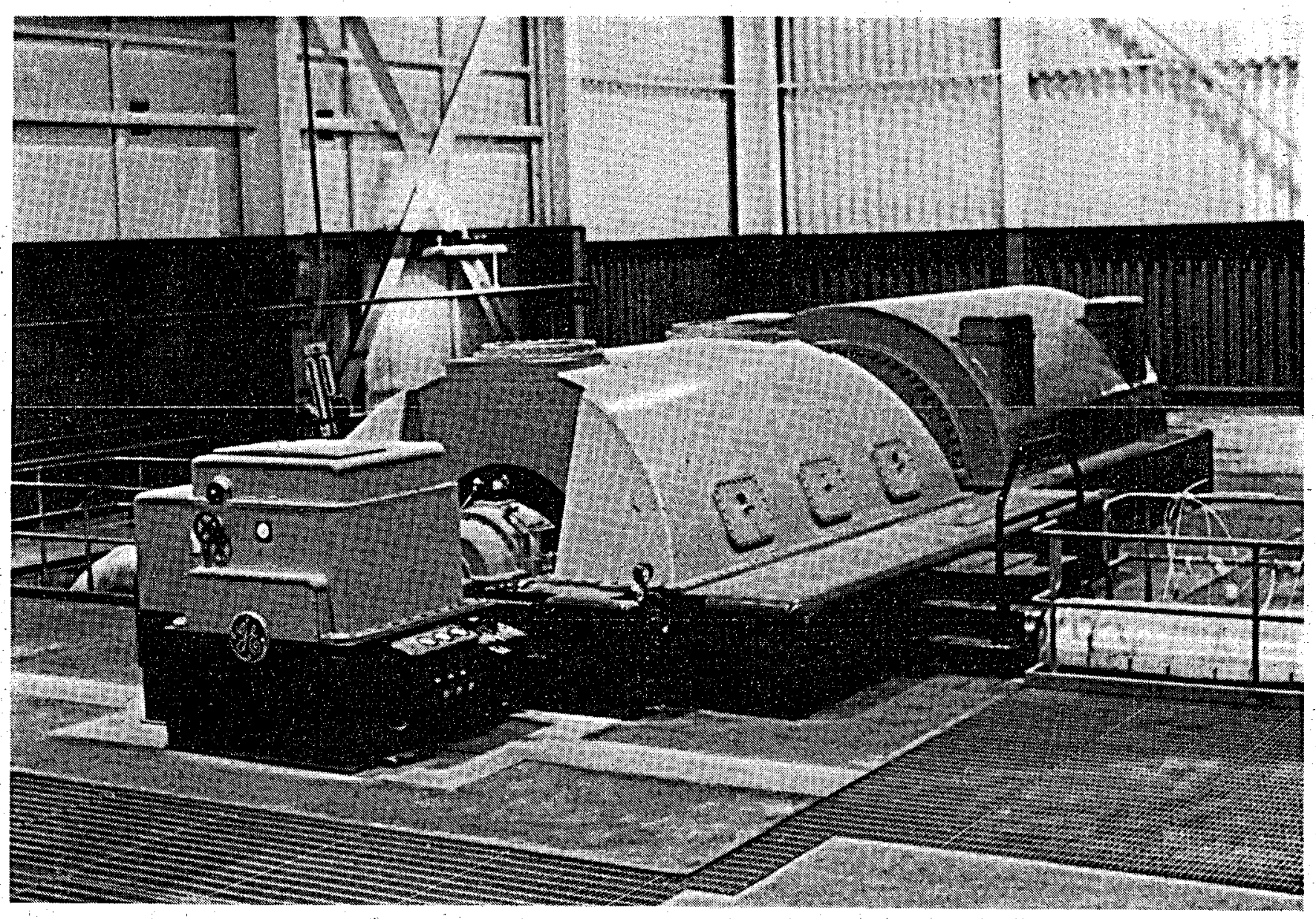

General Electric Co. Steam Turbine in use in Unit 15 at The Geysers. Courtesy of General Electric Co. 
The geothermal resource has both old and new friends in the public utility industry, and recent actions within the industry indicate a positive attitude toward the use of this resource. Future plans include both Increased purchases of power generated by non-utillty geothermal plants and greater capacity for the generation of power with both natural dry steam at The Geysers and the liquid-dominated resource in other areas. This is espectally significant at a time of lower than previously expected increases in power demand.

\section{DEVELOPMENT AT THE GEYSERS}

The Pacific Gas and Electric Co. (PG\&E) has by far the longest and most profitable utility experience with this resource, having operated at The Geysers since 1960. The company currently has 1137 MWe of capacity at that location which in 1.983 produced a record six billion $k w h$ of electricity, or 8.4 percent of the total power avallable for sale to PG\&E cus-: tomers. Two additional $110 \mathrm{MWe}$ plants are under construction, and construction on another 110 . Whe unit will start in 1985 . In addition, four more units of this size are planned for completion from 1989 to 1991 or beyond, as demand requires.

PG\&E is further expanding its commitment at The Geysers with the construction of a $\$ 40$ milition on-site administrative and maintenance facility. This facility will allow the company to perform nearly all necessary repairs and malntenance work at the remote location of Its operations at The Geysers, improving productivity and plant operating efficiencies.
While PG\&E 1s still the only regulated, Investor-owned utility operating at The Geysers, municipal utilities are also tapping this field. The Northern California Power Agency (NCPA), the membership of which comprises 11 cities and a rural electric cooperative, has one 110 MWe plant onIIne and another under construction. The Sacramento Municipal Utility District (SMUD) has completed a 72 MWe plant, and other plants are in planning stages under the aegis of the Central California Power Agency whose membership includes SMUD, the Modesto Irrigation District (MID), and the City of Santa Clara. The first non-utility plant ( $80 \mathrm{MWe}$ ) was constructed by Occidental Geothermal, but is now owned by Santa Fe Geothermal.

\section{DEVELOPMENT OF LIQUID-DOMINATED RESERVOIRS}

All of this activity at The Geysers is not unexpected since use of this field is a proven, successful, economic venture, for both the utilities and the steam suppliers. Current utility activities in the "hot water" segment of the geothermal industry are more dramatic because the technologles for power production with the Ilquid resource are relatively new and proven only by small pilot-scale units. At this juncture, however, several factors are stimulating. growth in hot water power production.

\section{NON-UTILITY GEOTHERMAL POWER PLANTS-EFFECTS OF PURPA}

A major factor stimulating nonutility firms to bulld geothermal plants to generate power for utility 
purchase is the Public Utility Regulatory Policies Act (PURPA). The incentives it provides include:

- exemption of qualifying plants (less that $80 \mathrm{MWe}$ ) from federal and state utility regulation

- a mandate to electric utilities to purchase power from small producers and provide them back-up power

- exemption of interconnection with a utility's system from lengthy Federal Energy Regulatory Commission (FERC) fact-finding hearings

- required avoided-cost rates for the purchased power.

Thus, independent geothermal power plant operators are freed from the regulated rate of return imposed on utilities and are provided a ready market for their product at somewhat more attractive returns on their investment. They are also free to negotiate higher than avoided-cost rates.

Not surprisingly, a group of investor-owned utilities challenged the FERC regulations implementing PURPA in the courts. However, the list of plaintiff utilities did not include any from the states where geothermal power plants are likely to be a factor in the near future. Neither was there a challenge to the California state statute (Private Energy Procedures Power Act) and regulations that impose PURPA-type requirements. The PURPA regulations were unanimously upheld, and appear to have the support of western utilities.

SDG\&E reported to its stockholders in its 1983 Annual Report that it is encouraging others to build geo- thermal plants and sell energy to the company. In addition, the company has completed a power link with Mexicali, Mexico, and has contracted to buy geothermally-produced power from the large plant at Cerro Prieto, Mexico.

Southern Callfornia Edison, owner of two of the three small plants in Imperial Valley - part owner with the Los Angeles Department of Water and Power and others, in one case -has succeeded SDG\&E as the purchaser of the power from the Magma plant, and just recently began purchasing the output of one small binary plant at Mammoth, California. In addition, SCE has commitments to buy power from additional geothermal plants when they are completed.

Sierra Pacific Power Co. (SP\&P) of Reno, Nevada, has also contracted to purchase the output of three small pllot-scale plants to be constructed at separate sites in Northern Nevada by three individual development companies. While these plants will be small in size - 10,9 , and 5 MWe respectively - they are approved by the state Public Service Commission for the commercial sale of electric1ty.

In this case, Sierra Pacific's interest goes beyond the purchase of 24 MWe of power. Each plant will ut1lize a different type of power conversion technology, and the utility's contracts provide it access to all data concerning the quality of the geothermal resources, plant performance, and operating and maintenance costs. With this knowledge, Sierra Pacific w111 be able to determine which type plant is the most efficient and cost-effective.

The company hopes to achieve several goals with these projects: 
- to prove the economic and technical feasibility of commerclal power generation in Northern Nevada by 1988

- to galn Information from the plants that will ultimately lead to the development of larger base-load generating plants in the early 1990's

- to have geothermal resources supply 25 percent of the energy needs of 1 t's customers by the year 2000 .

A longer-term contract with one of the three developers w111 allow Sierra Pacific the right to assume ownership after 16 years of operation. If the plant is successful, it could be the next step toward the company's goals.

Sierra Pacific has stated that a key benefit of geothermal power plants "Is that they require only two to three years to construct and bring online, compared to elght to ten years for a coal-fired plant and twelve to fifteen years for a nuclear plant." If small geothermal plants can be constructed rapidly at competitive costs, Sierra Pacific feels that this w111 facilitate increases in energy resources to more closely match the electricity demands of its customers.

Staged development is underway near Lakeview, Oregon, where the initial units total only 1.9 MWe. Incremental development up to 10 MWe is anticlpated. Paclfic Power and L1ght Co. (PP\&L) purchased the output of the units during long-term testing, and has contracted to buy their production once they are in continuous operation.

NON-UTILITY GEOTHERMAL POWER PLANTS - - EFFECTS OF FEDERAL ENERGY TAX CREDIT

The financial benefit offered by the business energy investment tax credit has offered the other major incentive for non-utility firms to engage in the production and sale of geothermally-generated electric power. First provided by the Energy Tax Act of 1978, the tax credit was increased to 15 percent by the Crude $0 i 1$ Windfall Profits Tax Act of 1980. However, it will end on December 31, 1985.

The tax credit has played a role during its brief existence in the relative economics of utility and nonutility construction and operation of geothermal power plants since the credit is not available to utilities. In one important instance, a major geothermal fleld developer joined forces with a large multi-interest engineering corporation to take dual advantage of tax incentives - - 1.e., the intangible drilling cost deduction and depletion allowance for field development and the energy tax credit for the plant. These arrangements by Chevron Resources Inc and the Dravo Corporation have resulted in construction of a 49 MWe geothermal power plant at Heber.

In this case, Dravo was not Chevron's initial partner. Southern California Edison first applied to the California Public Utilities Commission for certification to bulld and operate the plant. In approving the plant, the CPUC ruled that the company's management and shareholders - rather than 1ts customers - should bear the financial risks of a geothermal plant, and $11 m$ ted its rate of return to avolded costs. In the company's view, this decision, particularly in the absence of the tax credit, rendered the plant uneconomic.

\section{UTILITY GEOTHERMAL POWER PLANTS}

The largest power plant under construction by a utility using $a$ 11quid-dominated reservoir is the 45 MWe SDG\&E binary plant at Heber. The federal government is particlpating in the cost of this plant since the 
efficiency and economics of binary technology in large-scale application have not yet been proven. Its interest is in the future development of many other geothermal reservolrs suitable for binary application.

Another Investor-owned utility engaged in geothermal power plant development is Utah Power and Light Co. (UP\&L). One UP\&L 20 MWe plant has just recently come on-line at Roosevelt Hot Springs, and two more has announced that 1 intends to develop the Roosevelt fleld to the fullest and hopes to accomplish this by 1995 .

The 1984 survey of U.S. util1ties by the Electric Power Research Institute resulted in the following projections of Increases in geothermal energy for power generation:

Announced

Probable

\begin{tabular}{cccccc}
\multicolumn{7}{c}{ Me Capac1ty } \\
\hline 1983 & 1985 & 1990 & 1995 & 2000 & 2005 \\
Actual & F1rm & Est. & Est. & Est. & Est. \\
\hline 1351 & 1780 & 2255 & 2441 & 2640 & 2640 \\
& & 2659 & 3103 & 3823 & 4512 \\
& & 3211 & 4944 & 6828 & 8007
\end{tabular}


ENERGY TAX CREDITS EXPIRING

Under the Deficit Reduction Tax Act of 1984 geothermal tax credits authorized by the National Energy Act of 1978 and a subsequent amendment will not be extended beyond December 31, 1985. Provisions for both the 40 percent residential tax credit for geothermal heating and cooling investments and the 15 percent business energy investment tax credit were dropped from the bill. However, th1s legislation does not affect the depletion allowance, deduction of intangible drilling costs, accelerated depreclation deduction, or federal tax exemption for interest on industrial development bonds used to f1nance certain geotherma 1 projects.

\section{GEOTHERMAL AT THE GEYSERS IS BIG BUSINESS}

Recent transactions at The Geysers show clearly that geothermal energy at that location is now big business. Santa $\mathrm{Fe}$ International has purchased the holdings of Occidental Geothermal - field development and 80 MWe power plant - for $\$ 350$ mililion. Union 011 also recently acquired Magma's original one-fourth share of The Geysers property once held joint1y by Union/Magma/Therma1, The Geysers developers, for $\$ 285$ million. The Magma property had passed Into other ownershlp. These figures cannot be put into clear perspective without knowledge of the acreage Involved, the extent of development, and other factors. However, the import of st1ll another transaction makes the value of properties in The Geysers area somewhat more readily understood. In 1983, Grace Geothermal pald Shell $0 i 1$ Co. $\$ 106$ million for two federal leases covering 4000 acres for which Shell inttlally paid the government only $\$ 4.5$ million. Assuming some development expenditures by Shell, this was still a highly profitable
Investment. The Northern Callfornia Power Agency is now offering Grace Geothermal $\$ 145 \mathrm{milli}$ on for the same leases.

DOE REQUESTS CONMUNITY PROPOSALS FOR RENEWABLE ENERGY DISTRICT HEATING AND COOLING ASSESSMENTS

DOE's Office of Building Energy Research and Development, through 1 ts Community R\&D Branch, issued a solicitation on October 12, 1984, seeking applications from communtiles where district heating and cooling systems (DHC) "could substantially increase energy efficiency and/or replace. scarce premium fuels with abundant and renewable energy resources." The grants of $\$ 30,000$ to $\$ 40,000$ each. would be provided to cover the cost of assessing opportunities for community district heating and cooling systems.

The assessment is considered to be the first phase of a three-phase process leading to the construction and operation of a district heating and coollng system. Phase II, preliminary design and financlng, and Phase III, final design and construction, would fall under the jurisdiction of the Department of Housing and Urban Development (HUD). The solicitation notes that HUD has funded several rounds of Phase II awards with technical support from DOE.

The deadilne for proposals was December 21, 1984. GPM 1s informed by the DOE Office of Procurement Operations that communitles which are interested may be placed on a malling list to recelve any simllar future solicitation. 
Requests for this service may be addressed to:

Office of Bullding Energy R\&D Federal and Community Projects Division

Communfty R\&D Branch

U.S. Department of Energy

1000 Independence Ave., S.W.

Washington, D.C. 20585

INNOVATIVE FINANCING INFORMATION

\section{AVAILABLE}

A gulde for local governments on third party financing for energy projects is now avallable from the California Energy Commission. This guide, "Innovative Financing for Local Government Energy Projects: Energy Savings at Little or No Cost," provides an overview of shared savings plans, leasing plans, third party ownership agreements; and federal tax considerations. For more Information contact the California Energy Commission, Local Government Assistance, 1516 9th St., MS-26, Sacramento, CA 95814 .

Source: Geothermal Energy 1/84

\section{GRC/DOE SPONSORED GEOTHERMAL ECONOMIC WORKSHOP}

A workshop on Geothermal EconomIcs and Related Institutional Factors was co-sponsored by the Geothermal Resources Council and DOE In Palm Springs, CA, May 21-23, 1984. Basic economic decision making and financing of geothermal projects were the central themes addressed by a number of Industry speakers and representatives of the Geo-Heat Center at Oregon Institute of Technology.

\section{HYBRID BINARY PLANT RECEIVES FEDERAL ASSISTANCE}

Construction of an innovative electric power plant at Honey Lake near Susanville, Callfornia, designed to use both geothermal binary techno1ogy and wood combustion is supported by a $\$ 2.5$ million DOE contract. The funds are to be used for wellfield development and plant design of the 23.7 MWe facility. A 55 MWe plant was originally planned, with participation by the California Department of Water Resources (DWR) and the U.S. Forest Service, in addition to DOE. However, test results of the first well drilled forced a reduction in the planned capacity, and the DWR and Forest Service backed out of the venture.

A second well was drilled with the January 1984 funding. Test results are incomplete, although first indicators are not good, and plans and schedules for the third well, and perhaps a fourth, are currently on hold.

The plant itself is to be built with private financing. It w111 use a wood-fired system topping cycle, an organic Rankine binary bottoming cycle, and geothermal heating of combustion air and organic working fluid.

\section{OTHER GEOTHERMAL FINANCING GUIDES AVAILABLE}

A Guide to Financial Assistance for Geothermal Energy (CEC Pub. \#50081-030) provides summary descriptions of various federal and state financlal programs and incentives available to geothermal projects including loan and grant programs, tax incentives, and tax-exempt bonds. Contact: CEC, Geothermal Program, 1516 - 9th St., MS-43, Sacramento, CA 95814, (916) 324-3493.

A Guide to Financing Small-Scale Geothermal Energy Projects (March 1983) was prepared by the Oregon Department of Energy. Contact: Oregon Dept. of Energy, Geothermal Program, Labor and Industries Bullding, Salem, OR 91310, (503) 378-2778. The publ1cation 18 free.

Source: The Geyser $9 / 84$ 
RESOURCE ASSESSMENT INDICATES UTAH DRY STEAM WELLS CAN PRODUCE INDEFINITELY

The rmaSource, Inc., a leading geophysical service firm, recently completed an assessment of the geothermal steam beneath the federal leases of Mother Earth Industries at Cove Fort, Utah. The company's report "conservatively" estimates the size of the resource at 125 MWe and predicted that the two existing wells could produce Indefinitely. These very stable production wells are approximately 1100 feet deep.

Mother Earth, in partnership with the City of Provo, is constructIng a power plant at the site to operate on four Ormat binary units with a total net capacity of 2.8 MWe. Three more wells are planned for 1985 , and plant capacity is expected to increase to 7.5-10 MWe by mid-1986.

According to $\mathrm{Mr}$. Bud Bonnett, manager of Provo CIty Light, "the resource is so dry the only water you could get out of those wells would be what you could condense out of the steam." While there is some question as to whether the wells are tapping a steam cap or steam reservolr, for now at least, the power plant is the first in this country outside The Geysers to operate on natural steam. The only other such plants in the world are located at Lardere110, Italy; Matsukawa, Japan; Los Azufres, Mexico; and Kamojang, Indonesla. The Ormat units are designed to operate on elther steam or 11quid.

Source: Communication wt th Provo City Light

\section{ANNUAL DOE PROGRAM MEETING FOCUSED ON HYDROTHERMAL DEVELOPMENT}

The U.S. DOE annual program review, Geothermal Technology Conference, was held In El Centro, Callfornia, October 16-19, 1984. A1- though these meetings have always been held in Washington, D.C., E1 Centro was selected in order to be close to the center of activities, narrow the focus to hydrothermal developments currently underway, and broaden participation to include presentations from the private sector. In addition to program overviews and technical presentations, the meeting included site visits to geothermal power plants in the Imperial Valley and the Cerro Prieto facilities in Mexico.

Conference attendees also witnessed the groundbreaking ceremonies for the Salton Sea Scientific Dri11ing Project. Major participants in this event included Patrick Collins, Under Secretary of Energy; John E. Mock; Director, Geothermal Technology Division; Harvey F. Bush, Executive Vice President, Bechtel Group, Inc.; Robert R. Dimock, Vice President, Project Development, Kennecott; and Dr. Wilfred A. Elders, Institute of Geophysics and Planetary Physics, University of California, Riverside. Bechtel won the DOE contract for providing the well which will be drilled on a Kennecott lease.

\section{MAGMA POWER INCREASING CAPACITY OF EAST MESA BINARY DEMONSTRATION PLANT}

Magma Power Co. has announced plans to increase its East Mesa binary demonstration plant from 10 MWe to 12.5. The extension, it is reported, will be financed by the proceeds of the purchase of 550,000 newly issued Magma shares by Dow Chemical Co. This transaction increased the holdings of Dow in Magma from 14.9 percent of the stock to 20 percent.

Source: Geothermal Report 12/15/84 


\section{UP\&L SUBSIDIARY ORGANIZED TO EXPLORE ENERGY RESOURCES}

In October 1984, Utah Power and Light (Salt Lake City, UT) announced the formation of a subsidiary, Energy National Inc. Energy National is designed specifically to explore and assist the development of the country's untapped energy resources. These resources could be small streams or dams, geothermal reservolrs, even waste heat from industrial processes that could be turned into electricity or other useful forms of energy.

"We see ourselves as a partner in energy development," Energy National President Frank N. Davis stated, and emphasized that Energy National has been established to help, not compete against, small power producers and cogenerators. "Federal law says we can't own controlling interest in any venture," he says, "and we can only participate or assist where we're welcome."

Source: Idaho National Engineering Laboratory Regional Progress Monitor $12 / 84$

\section{OTA HELD WORKSHOP ON GEOTHERMAL POWER}

The Office of Technology Assessment (OTA) was requested by the House Science and Technology Committee, Subcommittee on Energy Applications, to determine if U.S. utilities perceive new energy technologies such as geothermal as being of practical significance in providing alternative, flexible generating capacity. A workshop was held June 5,1984 , to establish the cost and performance of geothermal power plants and to determine utility view of the geothermal contribution to energy needs. Gibbs and Hill was contracted to provide cost and performance data on the flash steam technology option. Binary cycle technology was not considered viable for the 1990 timeframe, although $1 \mathrm{t}$ would be competitlve if the time were extended to the $1990^{\prime} \mathrm{s}$.

Geothermal power was seen as a viable option to the Western utilities represented at the meeting (SDG\&E, UP\&L, and PG\&E). They agreed that in units of 10-20 MW a geothermal plant could of fer base load capacity at a competitive cost utilizing a resource that would not escalate in price as does the more conventional 011, gas, or coal. The need for additional power by the year 1990 is minimal, however, making additional power plant planning and construction a minor activity, regardless of the energy source. The mid-1990's is a better timeframe.

\section{PUBLIC GEOTHERMAL POWER LINE TO LINK 14 COMMUNITIES TO THE GEYSERS}

A 40-mile electrical transmission line will link The Geysers geothermal field in Sonoma County with power distribution centers in the Sacramento Valley, The line, when completed in 1988, will help meet the energy needs of 14 Northern California communities and public utilities. Participants in the joint transmission project are the Sacramento Municipal Utility District (SMUD), the Northern California Power Agency (NCPA), and the City of Santa Clara.

The planned transmission line w111 carry power generated at several existing and future geothermal power plants at The Geysers to one of three possible locations where it can be used or shipped to electrical load control centers. The three possible termination sites are:

1. A new substation located near the town of Williams;

2. The Pacific Gas \& Electric Vaca-Dixon substation located near Vacaville; 
3. SMUD's Elverta substation located near Sacramento.

The joint owners of the project are now in the project's licensing phase. They are initiating the environmental, land, and engineering studies that are required by the project's principal 1lcensing agency, the California Energy Commission (CEC).

Source: Geothermal Resources Council Bulletin 11/1983

\section{SURGE IN CONSTRUCTION OF HOT WATER POWER PLANTS SHOWN IN TABLES}

In previous GPM 1ssues, only three data tables were used to list geothermal power plants operating in the U.S. and those under construction or planned, at The Geysers or elsewhere. With this issue, however, the surge of activity in the industry outside The Geysers justifies separate tables for the hot water plants under construction and planned. The lists of both the hot water and The Geysers plants are impressive and credibly illustrate the slogan: Geothermal energy is a here and now technology.

GPM will greatly appreclate hearIng of any corrections or additions needed in the tables.

Several abbreviations have been used in the tables as follows:

\section{KGRA's}

GE - The Geysers/Calistoga, CA

EM - East Mesa, CA

$B R$ - Brawley, $C A$

PU - Puna (not KGRA), HI

SS - Salton Sea, CA

ML - Mono/Long Valley, CA

WA - Wabuska, NV

LA - Lakeview, OR

RO - Roosevelt Hot Springs, UT

LD - Lightning Dock, MM
Plant Type

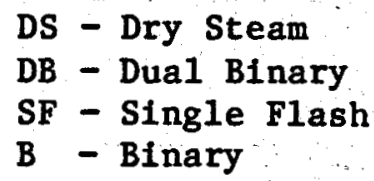

\section{Utilities}

PG\&E - Pacific Gas and Electric Co. SDG\&E - San Diego Gas and Electric Co.

SCE - Southern California Edison

HELCO - Hawal1 Electric Light Co.

NCPA - Northern California Power Agency

SMUD - Sacramento Municlpal Utility District

PP\&L - Pacific Power and Light Co. SPP - Sierra Pacific Power Co. UP\&L - Utah Power and Light Co.
NOTE: Future GPM Issues will report avallable data on the development status of direct heat applications in this section. In this issue, the direct heat statistics are part of THE FEDERAL SCENE progress report. 
gEOTHERMAL ELECTRIC POWER PLANTS OPERATIONAL IN THE UNITED STATES

\begin{tabular}{|c|c|c|c|c|c|c|c|}
\hline $\begin{array}{l}\text { LOCATION } \\
\text { (state and } \\
\text { KGRA*) } \\
\end{array}$ & PLANT NAME & $\begin{array}{l}\text { UNIT } \\
\text { NUMBER }\end{array}$ & $\begin{array}{l}\text { PLANT } \\
\text { TYPE }\end{array}$ & UTILITY & $\begin{array}{l}\text { YEAR } \\
\text { ON-LINE }\end{array}$ & $\begin{array}{c}\text { CAPACITY } \\
\text { MW }\end{array}$ & $\begin{array}{l}\text { CUMULATIVE } \\
\text { CAPACITY } \\
\text { MW }\end{array}$ \\
\hline $\begin{array}{l}\text { CA-GE } \\
\text { CA-GE } \\
\text { CA-GE } \\
\text { CA-GE } \\
\text { CA-GE } \\
\text { CA-GE } \\
\text { CA-GE } \\
\text { CA-GE } \\
\text { CA-GE } \\
\text { CA-GE } \\
\text { CA-GE } \\
\text { CA-GE } \\
\text { CA-GE } \\
\text { CA-GE } \\
\text { CA-GE } \\
\text { CA-EM } \\
\text { CA-BR } \\
\text { HI-PU } \\
\text { CA-SS } \\
\text { CA-GE } \\
\text { CA-GE } \\
\text { CA-GE } \\
\text { CA-GE } \\
\text { CA-GE } \\
\text { CA-HL } \\
\text { NW- } \\
\text { OR-LA } \\
\text { UT-RO } \\
\text { NA-LD }\end{array}$ & $\begin{array}{l}\text { Geysers } \\
\text { Geysers } \\
\text { Geysers } \\
\text { Geysers } \\
\text { Geysers } \\
\text { Geysers } \\
\text { Geysers } \\
\text { Geysers } \\
\text { Geysers } \\
\text { Geysers } \\
\text { Geysers } \\
\text { Geysers } \\
\text { Geysers } \\
\text { Geysers } \\
\text { Geysers } \\
\text { East Mesa } \\
\text { Brawley } \\
\text { Demonstration } \\
\text { Puna } \\
\text { Salton Sea } \\
\text { Demonstration } \\
\text { Geysers } \\
\text { Geysers } \\
\text { Geothermal Project } \\
\text { SMUDGEO } \\
\text { Oxy Geothermal } \star \star \\
\text { Mammoth Geothermal } \\
\text { Project } \star \star \\
\text { Wabugka } \star \star \star \\
\text { Lakeview } \star \star \star \star \\
\text { Blundell I } \\
\text { Burgett Floral, Inc. }\end{array}$ & $\begin{array}{r}1 \\
2 \\
3 \\
4 \\
5 \\
6 \\
7 \\
8 \\
9 \\
10 \\
11 \\
12 \\
15 \\
13 \\
14 \\
1\end{array}$ & $\begin{array}{c}\text { DS } \\
\text { DS } \\
\text { DS } \\
\text { DS } \\
\text { DS } \\
\text { DS } \\
\text { DS } \\
\text { DS } \\
\text { DS } \\
\text { DS } \\
\text { DS } \\
\text { DS } \\
\text { DS } \\
\text { DS } \\
\text { DS } \\
\text { DB } \\
\text { SF } \\
\text { SP } \\
\text { SF } \\
\text { DS } \\
\text { DS } \\
\text { DS } \\
\text { DS } \\
\text { DS } \\
\text { B } \\
\text { B } \\
\text { B } \\
\text { SF } \\
\text { B }\end{array}$ & 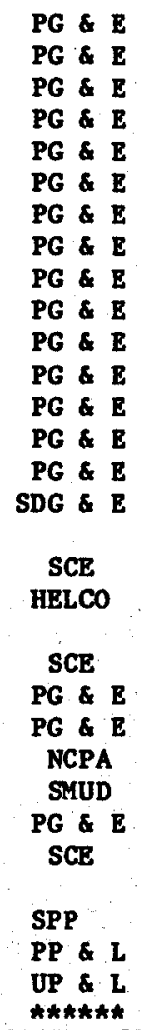 & $\begin{array}{l}1960 \\
1963 \\
1967 \\
1968 \\
1971 \\
1971 \\
1972 \\
1972 \\
1973 \\
1973 \\
1975 \\
1976 \\
1979 \\
1980 \\
1980 \\
1980 \\
1980 \\
1981 \\
1982 \\
1982 \\
1983 \\
1983 \\
1983 \\
1984 \\
1984 \\
1984 \\
1984 \\
1984 \\
1984\end{array}$ & $\begin{array}{r}11 \\
13 \\
27 \\
27 \\
53 \\
53 \\
53 \\
53 \\
53 \\
53 \\
106 \\
106 \\
55 \\
135 \\
110 \\
10 \\
10 \\
3 \\
3 \\
10 \\
110 \\
110 \\
110 \\
72 \\
80 \\
7 \\
11 \\
1 \\
20 \\
<1\end{array}$ & $\begin{array}{r}11 \\
24 \\
51 \\
78 \\
131 \\
184 \\
237 \\
290 \\
343 \\
396 \\
502 \\
608 \\
663 \\
798 \\
908 \\
918 \\
\\
928 \\
931 \\
\\
941 \\
1051 \\
1161 \\
1271 \\
1343 \\
1423 \\
1430 \\
1431 \\
1457 \\
1456 \\
1456+\end{array}$ \\
\hline
\end{tabular}

* Known Geothermal Resources Area

** Now owned by Santa Fe International

***Plant owned by Mammoth-Pacific, a joint venture of Pactfic Energy Resources and
**** Plant owned by Tad's Enterprises

***** Plant owned by Wood and Assoclates

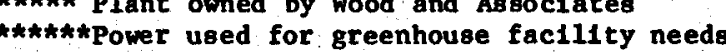


DRY STEAM GROTHERMAL, POWER PLANTS UNDER

CONSTRUCTION AT THE GEYSERS

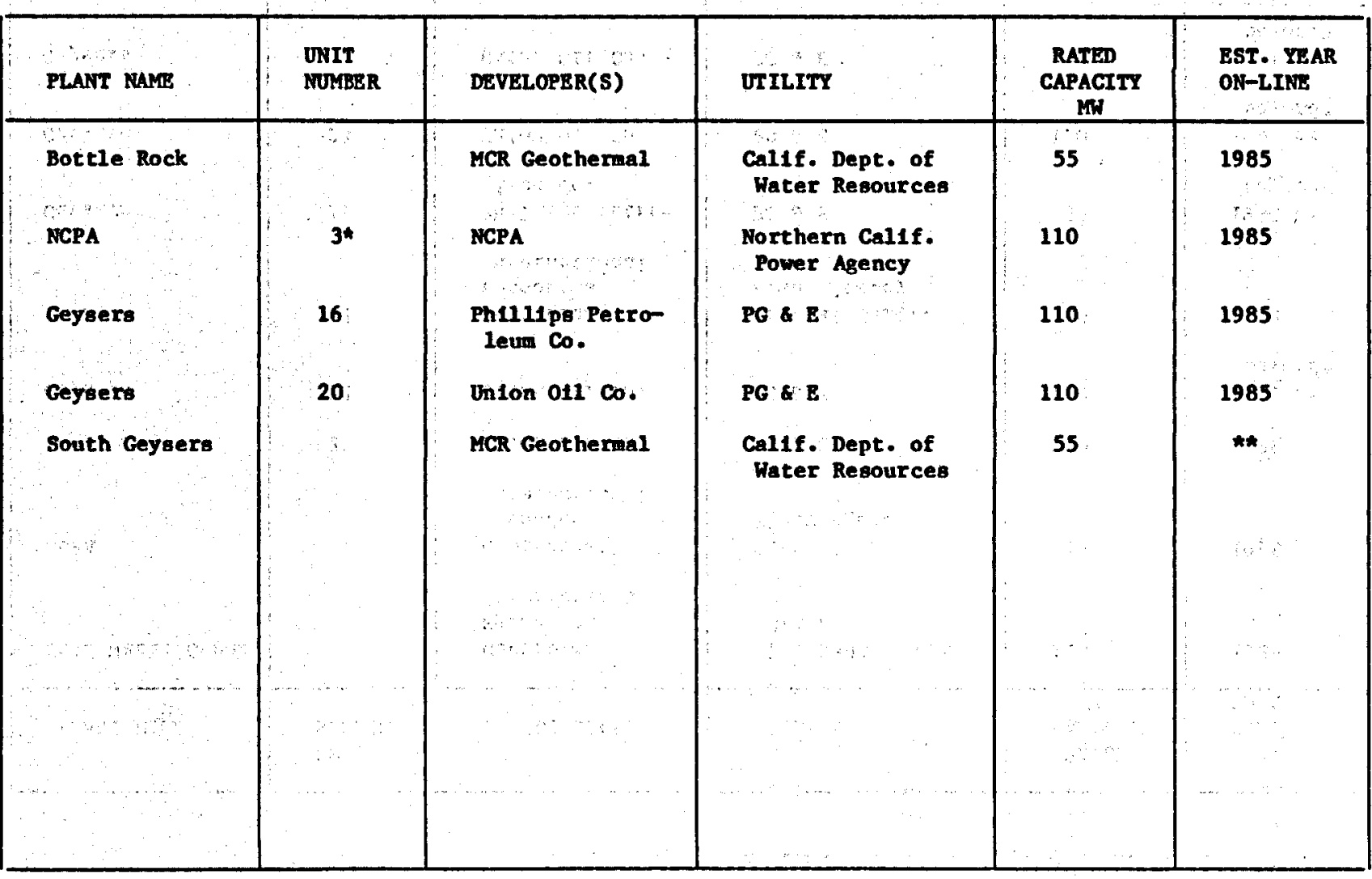

*There are only two NCPA plants Involved; resource. was not adequate for planned Unft No. 1. * Construction held up. 
PLANNED DRY STEAM GEOTHERMAL POWER PLANTS

AT THE GEYSERS

\begin{tabular}{|c|c|c|c|c|c|}
\hline PLANT NAME & $\begin{array}{l}\text { UNIT } \\
\text { NUMBER }\end{array}$ & DEVELOPER(S) & UTILITY & $\begin{array}{l}\text { RATED } \\
\text { CAPACITY } \\
\text { MW }\end{array}$ & $\begin{array}{l}\text { EST. } \\
\text { YEAR } \\
\text { ON-LINE } \\
\end{array}$ \\
\hline Cold Water Creek & & $\begin{array}{l}\text { Geothermal } \\
\text { Resources } \\
\text { International }\end{array}$ & $\begin{array}{l}\text { MID, SMUD, Santa } \\
\text { Clara }\end{array}$ & 120 & 1988 \\
\hline CCPA & 1 & $\begin{array}{l}\text { Geothermal } \\
\text { Resources } \\
\text { International }\end{array}$ & $\begin{array}{l}\text { Central Calif. } \\
\text { Power Agency }\end{array}$ & 55 & 1988 \\
\hline Geysers & 21 & Union o11 co. & PG $\mathbf{E}$ & 110 & 1988 \\
\hline Geysers & 22 & Unton 011 Co. & PG \& E & 110 & $\begin{array}{l}1989 \text { or } \\
\text { beyond* }\end{array}$ \\
\hline CCPA & 2 & $\begin{array}{l}\text { Geothermal } \\
\text { Resources } \\
\text { International }\end{array}$ & $\begin{array}{l}\text { Central Callf. } \\
\text { Power Agency }\end{array}$ & 20 & 1988 \\
\hline Geysers & 19 & $\begin{array}{l}\text { Phillips Petro- } \\
\text { leum Co. }\end{array}$ & PG $\mathrm{E}$ & 55 & $\begin{array}{l}1990 \text { or } \\
\text { beyond* }\end{array}$ \\
\hline Geysers & 23 & Unton $011 \mathrm{co}$ & PG \& E & 110 & $\begin{array}{l}1990 \text { or } \\
\text { beyond* }\end{array}$ \\
\hline Geysers & 24 & Union $011 \mathrm{Co}$. & PG $\mathrm{E}$ & 110 & 1991 or \\
\hline
\end{tabular}

*Plans will depend on capacity needs. 
HOT WATER GEOTHERMAL POWER PLANTS

UNDER CONSTRUCTION IN THE U.S.

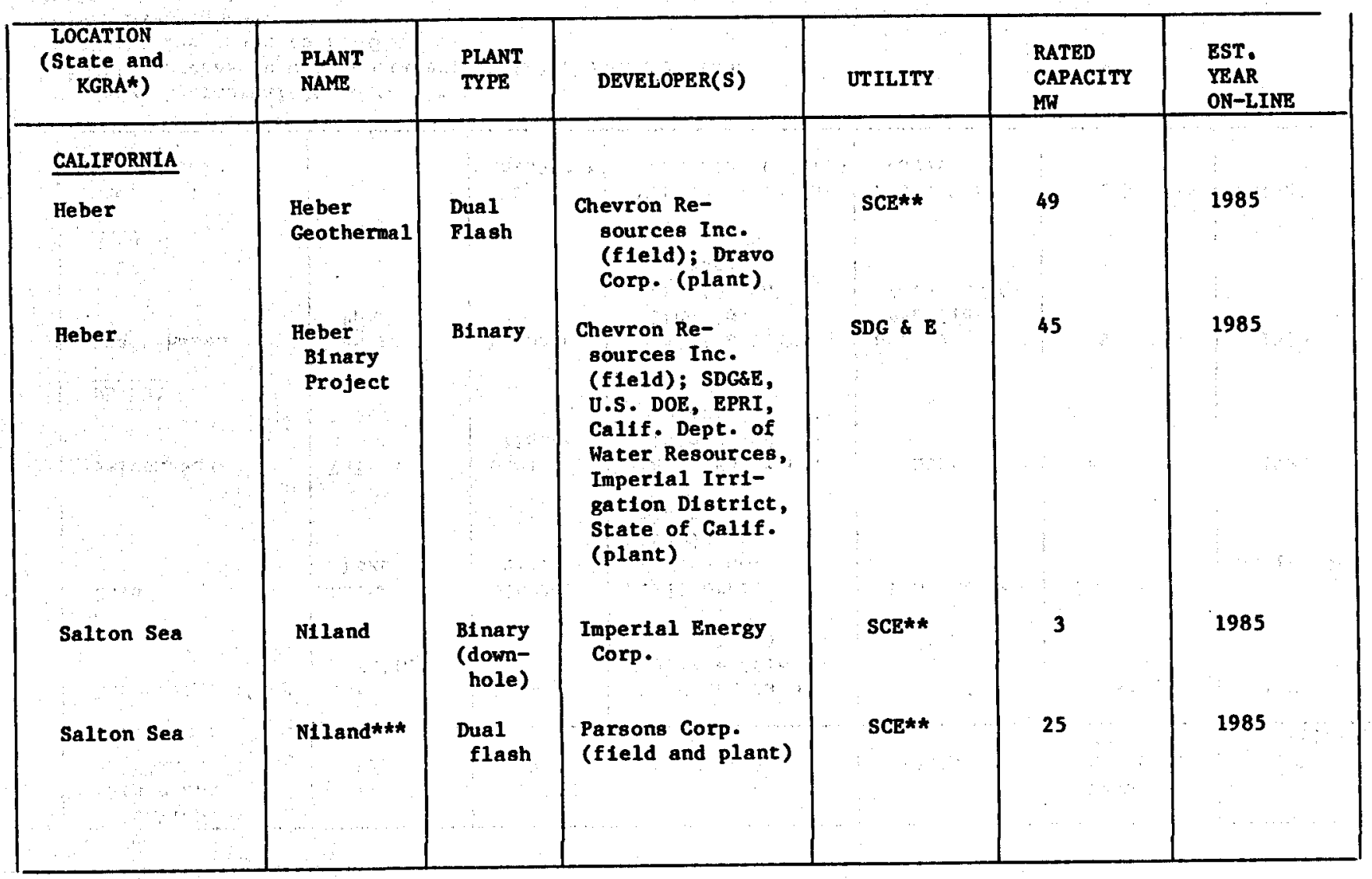

* Known Geothermal Resources Area.

** Purchases power generated; does not operate plant.

$* \star *$ (BDITOR'S NOTE: Construction of this plant has been cancelled.) 
HOT WATER GEOTHERMAL POWER PLANTS

UNDER CONSTRUCTION IN THE U.S., Continued

\begin{tabular}{|c|c|c|c|c|c|c|}
\hline $\begin{array}{l}\text { LOCATION } \\
\text { (State and } \\
\text { KGRA*) }\end{array}$ & $\begin{array}{l}\text { PLANT } \\
\text { NANE }\end{array}$ & $\begin{array}{l}\text { PLANT } \\
\text { TYPR }\end{array}$ & DEVELOPER(S) & UTILITY & $\begin{array}{l}\text { RATED } \\
\text { CAPACITY } \\
\text { MW }\end{array}$ & $\begin{array}{l}\text { EST. } \\
\text { YEAR } \\
\text { ON-LIRE }\end{array}$ \\
\hline Mono-Long Valley & $\begin{array}{l}\text { Long } \\
\text { Valley }\end{array}$ & BInary & $\begin{array}{l}\text { Wood and Asso- } \\
\text { clates (field } \\
\text { and plant) }\end{array}$ & $\operatorname{sCg} \star *$ & $3 k * k$ & 1986 \\
\hline Coso & $\begin{array}{r}\text { China } \\
\text { Lake }\end{array}$ & $\begin{array}{r}\text { Single } \\
\text { flash }\end{array}$ & $\begin{array}{l}\text { California } \\
\text { Energy Co. } \\
\text { (fleld and } \\
\text { plant) }\end{array}$ & U.S. Navy** & $25 * \star * *$ & $\begin{array}{r}1985 \text { or } \\
\text { ear1y } 1986\end{array}$ \\
\hline $\begin{array}{l}\text { Salton Sea } \\
\text { NEVADA }\end{array}$ & Vuican & $\underset{\text { flash }}{\text { Dual }}$ & $\begin{array}{l}\text { Magma Power Co. } \\
\text { (fleld and } \\
\text { plant) }\end{array}$ & SCE** & 34 & 1985 \\
\hline $\begin{array}{l}\text { Brady-Hazen } \\
\text { UTAR }\end{array}$ & $\begin{array}{l}\text { Desert } \\
\text { Peak }\end{array}$ & Biphase & $\begin{array}{l}\text { Phillips Petro- } \\
\text { leum Co: } \\
\text { (fleld and } \\
\text { plant) }\end{array}$ & $\begin{array}{l}\text { S1erra } \\
\text { Pacif1c } \\
\text { Power Co.** }\end{array}$ & 9 & 1985 \\
\hline $\begin{array}{l}\text { Cove Port/ } \\
\text { Sulphurdale }\end{array}$ & & 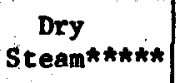 & $\begin{array}{l}\text { Mother Barth In- } \\
\text { dustries (field) }\end{array}$ & $\begin{array}{l}\text { Provo C1ty } \\
\text { Power }\end{array}$ & $2.5 * \pi \hbar k \star$ & 1985 \\
\hline
\end{tabular}

- Rnown Geothermal Resources Area.

** Will purchase power generated; will not operate plant.

***To be increased to $10 \mathrm{MWe}$.

$\star \star \star \star * 75$ Mwe planned.

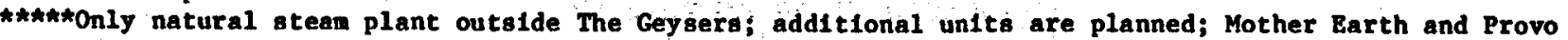
City Power joint owners of plant. 
HOO WATER GROTHERMAL FOWER PLANTS

PLANNED FOR CONSTRUCTION IN THE U.S.

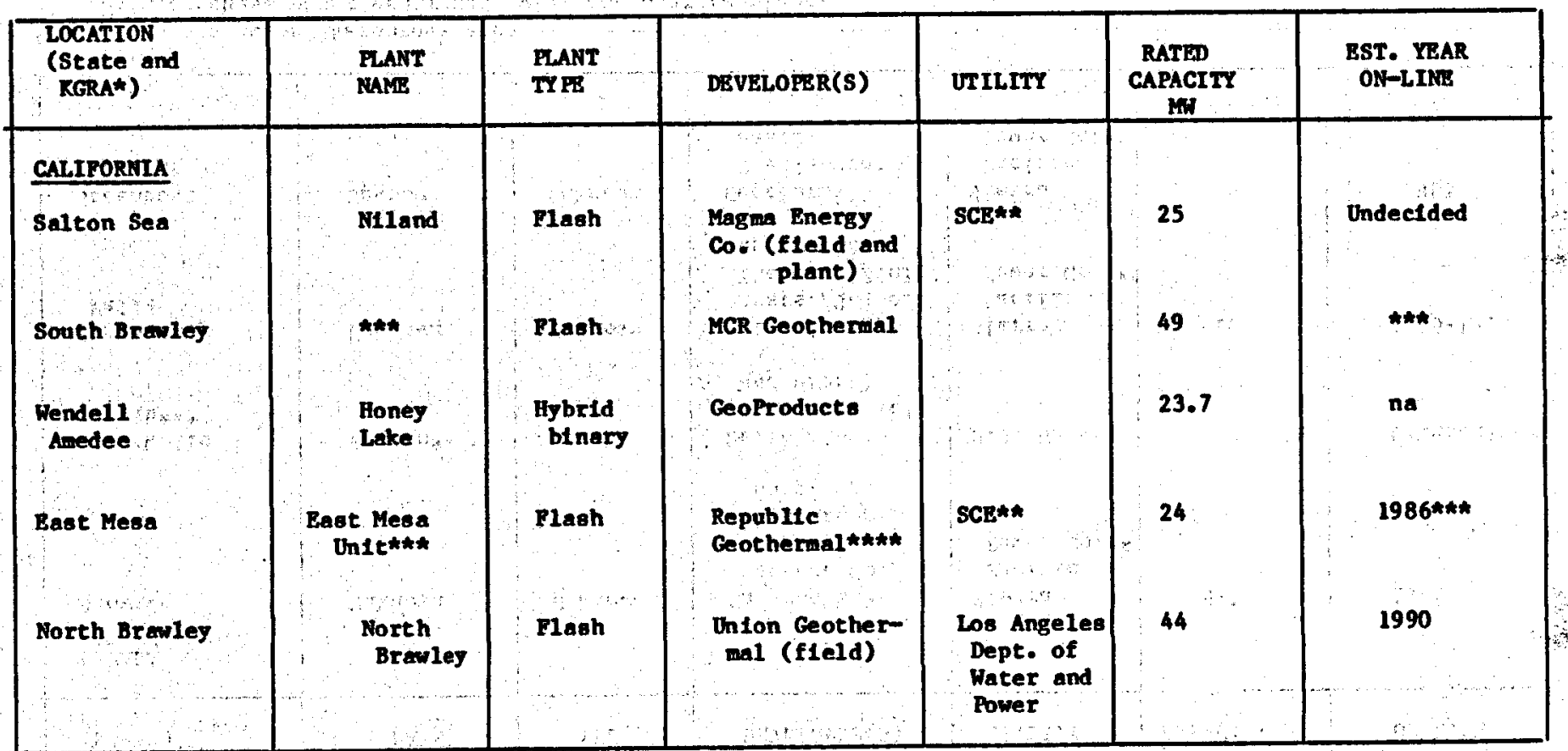

* Rnown Geothermal Resources Area.

* W111 purchase power generated; wili not operate plant.

*** (EDITOR'S NOTE: Plans for construction of this plant have been cancelled.)

*A** (EDITOR'S NOTE: OrMesa, a subsidiary of Ormat Systems, 1s negotiating financing to conetruct a 20 me blnary plant at this site.) 
HOT WATER GEOTHERMAL POWER PLANTS

PLANNED FOR CONSTRUCTION IN THE U.S., contInued

\begin{tabular}{|c|c|c|c|c|c|c|c|}
\hline $\begin{array}{l}\text { LOCATION } \\
\text { (State and } \\
\text { KGRA*) }\end{array}$ & & $\begin{array}{l}\text { PLANT } \\
\text { MAME }\end{array}$ & $\begin{array}{l}\text { PLANT } \\
\text { TYPE }\end{array}$ & DEVELOPER(S) & UTILITY & $\begin{array}{c}\text { RATED } \\
\text { CAPACITY } \\
\text { MW } \\
\end{array}$ & $\begin{array}{l}\text { EST. YEAR } \\
\text { ON-LINE }\end{array}$ \\
\hline NEVADA & & $\therefore$ & & $\therefore \therefore ;$ & 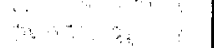 & & \\
\hline Beowawe & & Unknown & Unknown & $\begin{array}{l}\text { Chevron Re- } \\
\text { source Co./ } \\
\text { O'Br1en } \\
\text { Resources } \\
\text { Corp. }\end{array}$ & $\begin{array}{l}\text { Sierra } \\
\text { Pacific } \\
\text { Power Co.** }\end{array}$ & $5-10$ & 1985 \\
\hline 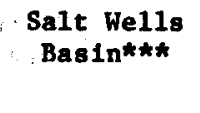 & & 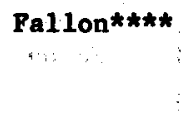 & Flash & $\begin{array}{l}\text { Helloscience } \\
\text { General (field } \\
\text { and plant) }\end{array}$ & U.S. Navy** & $y^{10 * k * * \star}$ & Unknown*k**: \\
\hline $\begin{array}{l}\text { B1g Smokey } \\
\text { Valley }\end{array}$ & & Unknown & Unknown & $\begin{array}{l}\text { Nat1. Energy } \\
\text { Assts./Sequola } \\
\text { Thermal (field } \\
\text { and plant) }\end{array}$ & $\begin{array}{l}\text { Slerra } \\
\text { Pacific } \\
\text { Power Co.** }\end{array}$ & $\because \quad 10$ & $1985-1986$ \\
\hline $\begin{array}{l}\text { Steamboat } \\
\text { Springs }\end{array}$ & ? & Unknown & Unknown & $\begin{array}{l}\text { Geothermal } \\
\text { Development } \\
\text { Assts. }\end{array}$ & $\begin{array}{l}\text { Sierra } \\
\text { Pacific } \\
\text { Power Co.** }\end{array}$ & 5 & 1985 \\
\hline 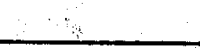 & & & & & 3 & & \\
\hline
\end{tabular}

* Known Geothermal Resources Area.

** W11l purchase power generated; will not operate plant.

** Now declassified as KGRA.

**** (EDITOR'S NOTE: Plans for construction of this plant have been cancelled.)

$\star \star \star \star \star$ Were to be Increased to 15-25 MWe within 3-5 years; 50-75 MWe within 5-7 years. 
HOT WATER GEOTHERMAL POWER PLANTS

PLANNED FOR CONSTRUCTION IN THE U.S., Continued

\begin{tabular}{|c|c|c|c|c|c|c|}
\hline $\begin{array}{l}\text { LOCATION } \\
\text { (State and } \\
\text { KGRA ) }\end{array}$ & $\begin{array}{l}\text { PLANT } \\
\text { NAME }\end{array}$ & $\begin{array}{l}\text { PLANT } \\
\text { TYPE }\end{array}$ & DEVELOPER(S) & UTILITY & $\begin{array}{l}\text { RATED } \\
\text { CAPACITY } \\
\text { MW }\end{array}$ & $\begin{array}{l}\text { EST. YEAR } \\
\text { ON-LINE }\end{array}$ \\
\hline \multicolumn{7}{|l|}{ NEVADA } \\
\hline Beowawe & Unknown & Unknown & Chevron Re- & Sterra & $5-10$ & 1985 \\
\hline 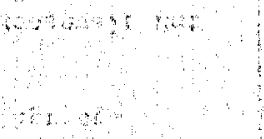 & 30 & 8000 & $\begin{array}{l}\text { source Co.l } \\
\text { O'Brien } \\
\text { Resources } \\
\text { Corp. }\end{array}$ & $\begin{array}{l}\text { Pacific } \\
\text { Power Co.** }\end{array}$ & 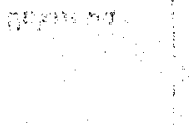 & $n$ \\
\hline${ }_{\text {Basint Wel }}^{\text {Salt }}$ & Fallonk*** & Flash & $\begin{array}{l}\text { Helioscience } \\
\text { General (fleld } \\
\text { and plant) }\end{array}$ & U.S. Navy丸* & $10 * * * * *$ & Unknown**** \\
\hline $\begin{array}{c}\text { Darrough } \\
\text { Hot Springs }\end{array}$ & Unknown & Unknown & $\begin{array}{l}\text { Nat1. Energy } \\
\text { Asats./Sequola } \\
\text { Thermal (f1eld } \\
\text { and plant) }\end{array}$ & $\begin{array}{l}\text { Slerra } \\
\text { Pac1f1c } \\
\text { Power Co.** }\end{array}$ & 10 & 1985-1986 \\
\hline $\begin{array}{l}\text { Steamboat } \\
\text { Springs }\end{array}$ & Unknown & Unknown & $\begin{array}{l}\text { Geothermal } \\
\text { Development }\end{array}$ & $\begin{array}{l}\text { Sterra } \\
\text { Pacific }\end{array}$ & 5 & $\approx 1985$ \\
\hline$a^{2}$ & & & $\cdots+4$ & 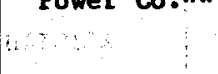 & & 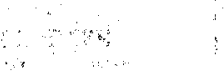 \\
\hline
\end{tabular}

* Known Geothermal Resources Area.

** W11l purchase power generated; 111 not operate plant.

$\star \star \star$ Now declassified as KGRA.

**** (EDITOR'S NOTE: Plans for construction of this plant have been cancelled.)

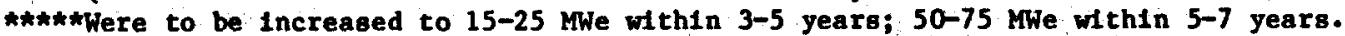


HOT WATER GEOTHERMAL POWER PLANTS

PLANNED FOR CONSTRUCTION IN THE U.S., Continued

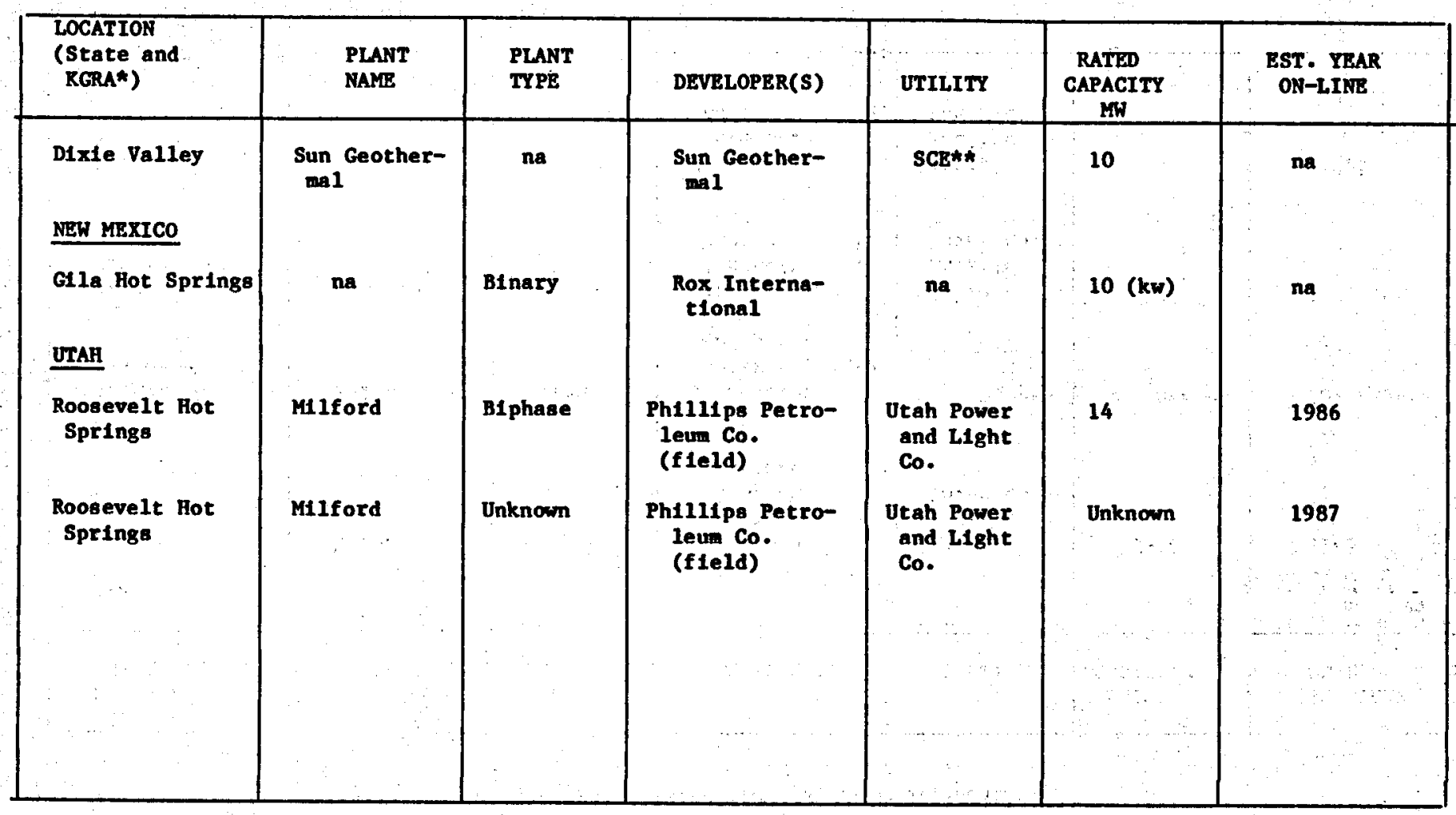

* Known Geothermal Resources Area.

** W111 purchase power generated; w111 not operate plant. 
TWO-YEAR EXTENSION OF CERTAIN GEOTHERMAL LEASES APPROVED BY CONGRESS

Supporters of geothermal-development have won congressional agreement on a two-year extension of certain geothermal leases. The Geothermal Steam Act requires several conditions before the primary lease term of 10 years can be extended, one of which is a contract for sale of the resource from producing or productble wells on the leasehold. Since the first geothermal leases were issued in 1974, a number of them have already expired or would do so in the coming months.

The importance of this is that substantial development Investments have been made on a number of these properties, but no sales contract is In place, primarily for two reasons. These are administrative delays in permitting beyond the control of the lessee and economic conditions that do not warrant utilization of the resource.

An amendment was attached to 1984 legislation (House Joint Resolution 648) that will relieve this situation. Sponsored by Senator Chic Hecht of Nevada, the amendment permits the Interfor Department to extend the term of leases in ef fect on July 27 , 1984 to December 31, 1986, but conditions the extension on a finding of substantial investment and administrative delays or unfavorable economic conditions. Emphasis is added since the last condition is extremely important at this juncture of geothermal development.

The amendment was offered by Sen. Hecht to protect 270 leases in seven western states. It will have the largest impact in Nevada where, Sen. Hecht asserted, 100 leases representing more than $\$ 50$ million in capital investment were in jeopardy.

The quick adoption of the amendment was the result of a trade-off with Sen. John Melcher of Montana to include in the legislation his proposal to ban geothermal leasing on 488,000 acres of federal land ad jacent to Yellowstone National Park. The ban 18 applicable to the Island Park KGRA in Idaho, Wyoming, and Montana, formerly known as the West Yellowstone KGRA.

Senator Hecht plans to introduce language In 1985 similar to the stopgap provision as an amendment to the Steam Act which would apply the new extension condition to all federal geothermal leases.

\section{INDUSTRY GEOTHERMAL DRILUNG ORGANIZATION FORMED - DOE WILL CONTRIBUTE TO PROJECTS}

A recent development that will accelerate the commerclalization of new geothermal drilling technology is the establishment of the Geothermal Drilling Organization (GDO). Its members include geothermal operators, service companies, Individuals, and laboratories involved with geothermal drilling. Its Charter meeting was held in August 1984, in Reno, NV, in conjunction with the annual meeting of the Geothermal Resources Counc11. The most recent meeting was held in E1 Centro in October just prior to the DOE 1984 Geothermal Program Review.

The GDO provides a means for groups of Industry partners to select critical projects and receive 50 percent cost-sharing from DOE (DOE has budgeted $\$ 1$ million for FY 1985). The emphasis is on developed technology which needs a final push to be transferred to industry. Two projects already approved for 1985 are (1) the selection of a logging company to build and commercially of fer a version of Sandia's high temperature acoustic borehole televiewer; and (2) a fleld experiment testing the use of foams in well cleaning and drilling. 
Anyone desiring more information about the GDO and its activities should contact Dr. James Kelsey, Geothermal Technology Division - 6241, Sandia National Laboratories, Albuquerque, NM 87185 .

\section{SALTON SEA SCIENTIFIC WELL TO BE AVAILABLE TO RESEARCHERS}

In October of 1984 , ground was broken for the Salton Sea Scientific Drilling Project, in which a well will be drilled at the southern edge of the Salton Sea, to be available for scientific experiments for a year. Present plans call for the well to be drilled about 6000 feet below the $300^{\circ} \mathrm{C}\left(572^{\circ} \mathrm{F}\right)$ depth, or about 10,000 feet, possibly encountering temperatures as high as $400^{\circ} \mathrm{C}$ $\left(752^{\circ} \mathrm{F}\right)$, which would make it one of the hottest wells drilled. This will be the first major project to be carried out under the auspices of the Interagency Accord on Continental Scientific Drilling between the U.S. Geologica1 Survey, DOE, and the Nationa1 Science Foundation. Reservoir evaluation and related geological, geochemical, and geophysical Investigations sponsored by this program may show that geothermal assets in the Imperial Valley are much greater than currently estimated.

\section{GEOTHERMAL ASSETS OF THE CASCADES RANGE UNDER INVESTIGATION}

Both DOE and the USGS are engaged in activities designed to help evaluate the geothermal potential of the Cascade Mountains of the Pacific Northwest, with DOE activities focused on development of exploration techniques. This region of active volcanism may contain a much larger geothermal resource than has been identified elsewhere in this country. Exploration for Cascades geothermal resources is impeded, however, by the presence of shallower, cooler aquifers and low vertical permeability. The Geothermal Research Program of the USGS supports a wide variety of studies in the Cascades including geologic mapping, geochronology, petrology of fresh and hydrothermally altered rock, fluid geochemistry, hydrology, and both regional and local geophysical surveys. DOE is cost-sharing with industry a number of $3000-4000$ foot heat-flow holes in order to develop techniques for penetrating beneath the "rain curtain."

\section{SINGLE BIDDER FOR VALE HOT SPRINGS LEASES MUST WAIT FOR INCREASE IN ACREAGE LIMITATION}

Only two parcels of the 10 of fered at BLM's April 24, 1984 lease sale in Portland, Oregon, received bids. Transpacific Geothermal Inc. submitted both bids for a total bonus of $\$ 41,895.63$ on 4804.93 acres. However, award of the leases to Transpacific would put the Oakland firm over the maximum 20,480 acres that it is permitted to hold in any one state under the Geothermal Steam Act. Unless Congress acts sooner to increase the limitation, the leases cannot be awarded until the Secretary of the Interior is permitted to do so administratively on the 15th anniversary of the Act -- December 24, 1985.

Acreage offered at the April 24, 1984 sale in the Breltenbush Hot Springs and Carey Hot Springs KGRA's received no bids.

Source: PI National Geothermal Service $4 / 27 / 84$

Geothermal Report 7/16/84

\section{GEYSERS TOP BID AT SEPTEMBER BLM LEASE SALE DENIED}

Aminoil USA and Phillips Petroleum offered the high bids for two parcels near The Geysers geothermal steam field in northern Callfornia's 
Sonoma and Lake counties at a geothermal lease sale held September 25, 1984 by the Bureau of Land Management in Sacramento. Aminoil bid $\$ 469.17$ per acre or a total of $\$ 408,055.91$, for one parcel for the sale's high bid. The tract comprises 869.74 acres in Sonoma County between Little Sulfur and Big Sulfur Creeks on the southwest flank of The Geysers fleld area. BLM rejected the bid as too low, however, just as it previously rejected a higher bid of $\$ 700,000$ for the same tract. The company has the right to appeal the decision. Phillips of fered $\$ 271,156.80$, or $\$ 389.76$ an acre, for a 680-acre tract in Lake County some two miles south of Boggs Lake.

Total bonus at the sale was $\$ 786,201.49$, while bids averaged $\$ 21.83$ per acre. of the 51 parcels offered, for a total of $95,255.56$ acres, 20 tracts drew bids covering $36,015.24$ acres. Total exposure was $\$ 851,134.32$, as only four tracts drew multiple bids. The most active successful bidders were Geysers Geothermal, taking seven parcels in The Geysers KGRA, and oxy Geothermal, with five apparent high bids for acreage in the Lake City-Surprise Valley KGRA.

A11 but two of the 21 tracts offered in The Geysers area were reoffers, and half of these still. recelved no bids. of the 12 parcels offered In the Lake City-Surprise Valley KGRA, all were reoffers with. new acreage added to two parcels. These partial reoffers and six other tracts received bids. Only one parcel out of $s 1 x$ of fered in the Salton Sea KGRA recelved a bid for a low $\$ 2.55$ per acre. No Interest was expressed in the East Brawley, Dunes, or Glamls KGRA parcels. The acreage originally offered in the Mono-Long Valley and Wende1-Amedee KGRA's was withdrawn by BLM prior to the sale.
Source: PI National Geothermal Service $10 / 5 / 84,8 / 17 / 84$

\section{HIGH BIDS TOTAL NEARLY \$120,000 AT NEVADA KGRA SALE}

Only seven of the 48 tracts offered drew bids at a KGRA sale held by the Bureau of Land Management in Nevada, September 27, 1984. Total bonus at the sale was $\$ 119,373.26$, an average of $\$ 8.82$ per acre. Of the $98,076.43$ acres offered, only 13,532 acres were leased. Munson Geothermal was the high bidder on five of the seven parcels sold, four in the BradyHazen KGRA, where the company is reportedly considering construction of a power plant, and one in Dixie Valley. Union 011 Co. of California was the other high bidder in Dixie Valley, and an Individual successful$1 y$ bid acreage in the Kyle Springs KGRA: The last BLM lease sale in Nevada in 1982 drew no bids.

Source: (Partially) PI National Geothermal Service $7 / 27 / 84$

\section{NO BIDS RECIEVED ON UTAH GEOTHERMAL LEASES AT MARCH 26 SALE}

No bids were received for geothermal leases offered March 26 by the Utah Department of Natural Resources, Division of State Lands, in Salt Lake City. The sealed bid offering included nine geothermal tracts. comprising 6461.18 acres in Beaver and Millard counties.

Source: PI National Geothermal Service

$$
3 / 30 / 84
$$

\section{COMMERCIAL GEOTHERMAL WELL DRILED} AT FISH LAKE, NEVADA

Steam Reserve Corp., a subsidiary of Amax Exploration, has announced 
completion of a commercial geothermal well at its Fish Lake prospect in Esmerelda County, Nevada, about 45 miles west of Tonopah. The well bottomed at 8149 feet in a fracture zone in Paleozolc Harkless formation with well temperature near $204^{\circ} \mathrm{C}$ $\left(400^{\circ} \mathrm{F}\right)$. The Amax announcement sald the well has shown the capability to support $3-4$ megawatts of generatIng capacity under self-flow, and pumped flow would be expected to enhance the capacity significantly, The site is about 40 miles from Bishop, Callfornia, where transmission lines are avallable for carrying power to Southern Callfornia markets.

Source: Geothermal Report 8/15/84

NORTHERN CALIFORNIA POWER AGENCY TRIES TO SEIZE FEDERAL LEASE IN CALIFORNIA

A court battle is underway in Callfornia between a municipal power agency and a private geothermal company that supplies the power company with steam. The Northern California Power Agency (NCPA) claims that Grace Geothermal Company (which is not related to W.R. Grace Company, the large New York-based energy and natural resources company) is not drilling as many geothermal wells as it sald it would. Grace produces the steam from land leased from the federal government. After offering to: buy the lease from Grace and being rebuffed, NCPA passed a resolution of necessity to use eminent domain authority to condemn the lease.

This is thought to be the first time a municipal government agency has tried to use eminent domain to secure control over a federal lease. Grace took NCPA to court to stop the condemnation and succeeded in obtaining a preliminary injunction against the power agency. Grace now wants an unspecified amount in damages and a permanent injunction against seizure of the lease.

In Washington, Interior Department attorneys are reviewing the case to determine whether NCPA can legally use the eminent domain authority. According to Project Manager James Whalen, NCPA offered Grace $\$ 145$ million for the lease after it decided Grace was not supplying the 110-megawatt geothermal plant. Grace executives sald they were surprised when NCPA made its purchase offer more than a month ago, signaling the beginning of the condemnation proceedings. "This was very much out of the blue," Grace spokesman James Rosenwald said.

The private company thinks NCPA's bid for eminent domain could affect other energy leases on federal lands. "The Importance of this is precedent not just geothermal, but oil, gas, coal, minerals, any type of drilling or mining operation. It sets a precedent so far never tested," Rosenwald said. (EDITOR'S NOTE: The court has ruled for Grace, and it is reported that NCPA is now purchasing the leases for $\$ 165$ milition.)

Source: The Energy Daily 11/5/84

\section{NUMBER OF 1984 HOT WATER DEVELOPMENT WELLS UP FROM 1983 BUT WILDCAT ACTIVITY DOWN}

As would be expected, the number of hot water development wells drilled in 1984 is more than double the number drilled in 1983. The increases are in the Salton Sea, Heber, East Mesa, and Coso KGRA's to support power plants under construction in those areas. On the other hand, wildcat wells spudded in 1984 number only about half of 1983 's total. 
GETHERMAL HOT WATER DEVELOPMENT WELLS SPUDDED (1981-1984)

Area

Californta

Salton Sea

$$
\text { Heber }
$$

East Mesa

Mono-Long Valley

Coso Hot Springs

Indian Valley Hot Springs

Brawley

Wende1-Amedee

Alaska

Hawa11

New Mexico

Redondo Creek

Dona Ana County

1983

1984

Utah

Roosevelt Hot Springs

TOTAl

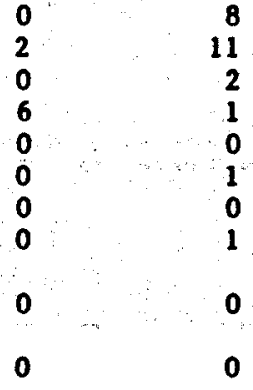

Source: PIC National Geothermal Service 
GEOTHERMAL HOT WATER WILDCAT WELLS SPUDDED (1981-1984)

Area

1981

1982

1983

1984

Californta

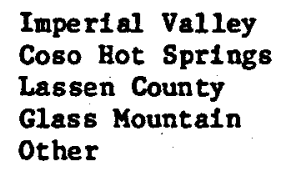

Colorado

Hawa11

Oh1o

Montana

Nevada

Esmerelda County

Churchill County Other

New Mexico

Dona Ana County

Sandoval County

New York

\section{Oregon}

Deschutes County Other

Utah

Cove Fort-Sulphurdale

TOTAL
0

0

3

0

0

0

$\begin{array}{ll}7 & 4 \\ 1 & 2 \\ 1 & 0 \\ 0 & 2 \\ 0 & 2\end{array}$

1

1

6

0

0
8
3

4

2

0

0
4

0

2
0

0
0

41

14

17

10

Source: PIC National Geothermal Service 
U.S. GEOTHERMAL PRODUCTION AND WILDCAT WELLS COMPLETED 1973-1984

AK AZ Geysers Imp.Val. Other HI ID LA MD MT NM NV NY OR SD TX UT UT TOTAL

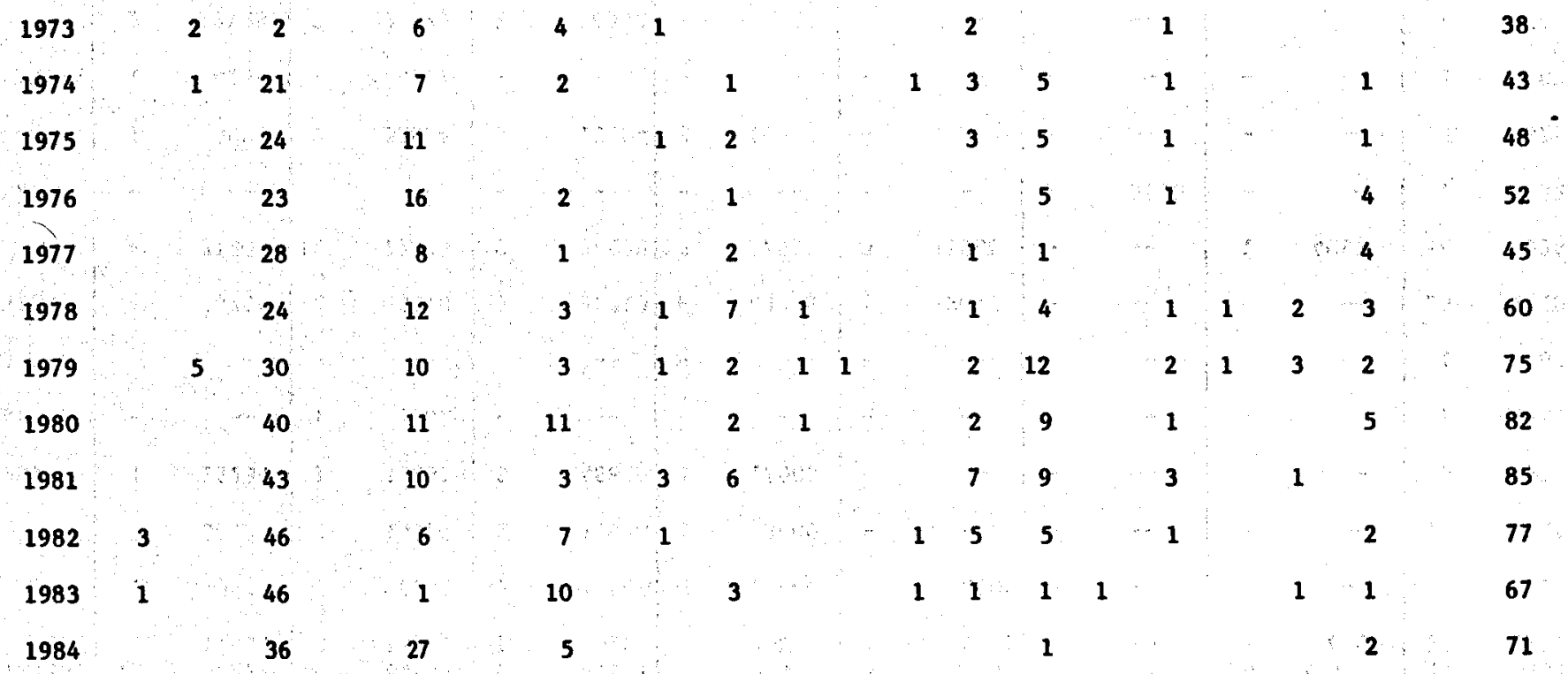

Total

$4 \quad 8.383$

125

51

826 

NUMBER OF DEEP WELLS (>2500) COMPLETED AND TOTAL FOOTAGE DRILLED
$1978-1984$

\begin{tabular}{|c|c|c|c|c|c|c|c|c|c|c|c|c|c|c|c|c|}
\hline \multirow{2}{*}{ STATE } & \multicolumn{2}{|c|}{1978} & \multicolumn{2}{|c|}{1979} & \multicolumn{2}{|c|}{1980} & \multicolumn{2}{|c|}{1981} & \multicolumn{2}{|c|}{1982} & \multicolumn{2}{|c|}{1983} & \multicolumn{2}{|c|}{1984} & \multicolumn{2}{|c|}{ TOTAL } \\
\hline & No. & Footage & No. & Footage & No. & Footage & Ho. & Pootage & No. & Footage & No. & Footage & No. & Footage & No. & Footage \\
\hline ARIZONA & - & -- & 5 & 21235 & - & - & - & - & - & -- & - & - & - & - & 8 & 48923 \\
\hline $\begin{array}{l}\text { CALIFORNIA } \\
\text { Geysers } \\
\text { Imp. Valley } \\
\text { Other }\end{array}$ & $\begin{array}{r}24 \\
12 \\
3\end{array}$ & $\begin{array}{r}190183 \\
92227 \\
17035\end{array}$ & $\begin{array}{r}30 \\
10 \\
3\end{array}$ & $\begin{array}{r}208961 \\
64844 \\
13543\end{array}$ & $\begin{array}{r}42 \\
9 \\
1\end{array}$ & $\begin{array}{r}312418 \\
81591 \\
9104\end{array}$ & $\begin{array}{r}44 \\
10 \\
4\end{array}$ & $\begin{array}{r}347153 \\
52437 \\
25026\end{array}$ & $\begin{array}{r}43 \\
4 \\
1\end{array}$ & $\begin{array}{r}337745 \\
27791 \\
9076\end{array}$ & $\frac{45}{-}$ & $\begin{array}{c}389378 \\
-\end{array}$ & $\begin{array}{r}41 \\
36 \\
1\end{array}$ & $\begin{array}{r}322362 \\
219448 \\
6000\end{array}$ & $\begin{array}{r}387 \\
129 \\
22\end{array}$ & $\begin{array}{r}2990470 \\
845369 \\
137168\end{array}$ \\
\hline HAWAII & 1 & 5595 & 1 & 6500 & 2 & 15000 & 2 & 15640 & 1 & 8005 & - & - & - & - & 9 & 61313 \\
\hline IDAHO & 7 & 38385 & 2 & 14356 & 2 & 11936 & 1 & 3000 & - & - & - & -- & - & - & 18 & 113524 \\
\hline LOUISIARA & 1 & 16234 & 1 & 15231 & 3 & 48626 & 1 & 17000 & - & - & - & - & - & - & 6 & 97091 \\
\hline MARYLAND & - & - & 1 & 5562 & - & - & - & - & - & - & - & - & - & - & 1 & 5562 \\
\hline MONTANA & - & - & - & - & - & - & - & - & - & -- & - & - & - & - & 1 & 6790 \\
\hline NEW MXICO & 1 & 6254 & 2 & 13010 & 5 & 37313 & 6 & 43995 & 1 & 2645 & - & -- & - & - & 24 & 172068 \\
\hline NEVADA & 4 & 21503 & 12 & 72523 & 10 & 74038 & 12 & 87605 & 3 & 15906 & - & - & 1 & 4097 & 58 & 353458 \\
\hline NEW YORK & - & -- & - & - & - & -- & - & -- & - & - & 1 & 5250 & - & - & 1 & 5250 \\
\hline OREGON & 1 & 4003 & 2 & 12874 & 3 & 13004 & 3 & 16063 & - & - & - & - & - & - & 13 & 67564 \\
\hline SOUTH DAKOTA & 1 & 4266 & 1 & 4112 & - & - & - & - & - & - & - & - & - & - & 2 & 8378 \\
\hline TEXAS & 2 & 19128 & 3 & 24320 & 2 & 26942 & - & -- & - & - & - & -- & - & - & 7 & 70390 \\
\hline UTAR & 3 & 20742 & 2 & 17654 & - & $-\infty$ & - & - & 3 & 8543 & - & - & 1 & 3000 & 19 & 125719 \\
\hline TOTAL & 60 & 435555 & 75 & 494725 & 79 & 629972 & 83 & 607919 & 56 & 409711 & 46 & 394628 & 80 & 554907 & 705 & 5060114 \\
\hline
\end{tabular}

Source: MITRE Corp. (through 1982); PI National Geothermal Service (1983 - 1984) 


\section{ALASKA}

\section{ALASKA UNALASKA EXPLORATION PROJECT COMPLETED}

State geothermal commercialization team activities were completed with the 1ssuance of the final report of the Electric Power Generation Analys is for the Unalaska Geothermal Exploration Project. The study, prepared for the Alaska Power Authority, evaluates different geothermal power systems to generate electricity for the towns of Unalaska and Dutch Harbor. Because of uncertaintles in electric load forecasting, it is recommended that development occur in phases timed to growth in demand. A binary cycle system was selected. The "Reconnalssance Study of Energy Requirements and Alternatives Appendix: Unalaska" recommends for the near term the use of diesel driven generators, especially when they are equipped with waste heat recovery systems.

Source: Idaho National Engineering Laboratory Regional Geothermal Progress Mont tor $9 / 84$

\section{CALIFORNIA}

\section{MAMMOTH LAKES RECEIVES GEC GRANT FOR DISTRICT HEATING STUDY}

Mammoth County has recelved a grant from the California Energy Commission for a district heating feasibility study. A consultant, to be selected, wLll investigate the use of geothermal water for space and water heating of commercial buildings, hospitals, schools, condominiums, low cost housing projects, and possibly an Industrial park. A snow-melt system will also be considered in the design. Three resource options will be considered: 1) use of reject water from the binary power plant at Casa
Diablo Hot Springs, 3 to 5 miles distant; 2) free heat from a proposed Union oil Co. power plant ad jacent to the City; and 3) wells drilled by the City itself.

Source: Oregon Institute of Technology Geo-Heat Center

\section{USGS RETRACTS WARNINGS OF EARLY VOLCANIC ACTIVITY IN CALIFORNIA MAMMOTH LAKES AREA}

For two years the U.S. Geolog1cal Survey has issued various stages of alerts for volcanic eruption in the Mammoth Lakes area in California in the Mono-Long Valley KGRA. These alerts were prompted by earthquake swarms, changing temperatures in hot springs and fumaroles, and ground swelling. While USGS has not changed its long-term assessment of the likelihood of a volcanic upheaval in the area, a July 30, 1984 report noted that recession of the above symptoms has eased the early danger. "Th1ngs would have to pick up a lot before USGS would start worrying again about immediate eruption," a spokesman sald.

Source: Geothermal Report 8/15/84.

\section{CEC OFFERS UPDATED ELECTRICITY COST REPORTS}

An interim staff report entitled "Relative Cost of Electricity Production" is avallable from the Callfornia Energy Commission (CEC). The report presents CEC staff estimates of the annualized cost of electricity on a generic basis for 23 different technology-fuel combinations over the period 1990-2020.

Electricity costs are presented for technologies that are commerctally avallable or could begin operation by 1990. The cost of generation is calculated assuming that either a public or private utility constructs, 
owns, and operates the power plant. All costs are presented in both nominal (includes inflation) and real (excludes inflation) terms. The report also summarizes the economic and technical assumptions upon which the relative cost estimates are based.

To order the report, send a check or money order for $\$ 1.60$ per copy and a self-addressed malling label to the Commission's Accounting Office, 1516 Ninth Street, MS-2, Sacramento, CA 95814. Please request pub. no. P300-83-010. For further Information, call Mike Ringer at (916) 324-3201.

\section{Source: Geothermal Resources Counc1l} Bulletin 5/84

\section{SUCCESS STORY CONTINUES AT FORT BIDWELL INDIAN RESERVATION}

The Palute Indians at Fort B1dwe11, California, recently expanded their geothermal activities to include an aquaculture facility to raise catfish to be sold in metropolitan markets. Two wells were already in use to supply space heat for a new apartment complex for the elderly and a clinic and two tribal bulldings retrofitted to use the geothermal fluids as well as a small greenhouse.

Starting up in October 1984 , the two fiberglass raceways have recelved 6000 fingerlings, which will be increased to 40,000. They will. achleve a weight of about two pounds each in eight months, and are expected to sell at a retail price of $\$ 2$ per pound. The capacity of the well used for the project is sufficient to supply a total of 10 raceways. Others are expected to be installed since this operation and the greenhouse provide needed jobs to the community.

Source: Geo-Heat Center, Quarterly Bulletin, Fall 1984

\section{SUSANVILLE DISTRICT HEATING SYSTEM EXPANDING}

The geothermal district heating system of Susanville, Callfornia, originally cost-shared by DOE, has been operational for two years on a Iimited basis due to less than optimum performance of the injection well. Now that a state surface discharge permit has been granted -- difficult to obtain because the state considers the geothermal fluid a potentially hazardous waste - the system w111 operate at full design capacity during the 1984-1985 heating season.

Since the DOE grant was completed, three new buildings have been added to the system for a total of 16. As an outgrowth of the DOE project, a HousIng and Urban Development Department Innovative grant was used to develop a second loop to serve 126 homes. Twenty-three homes have been connected for service to begin in the fall of 1984. The wells for a third system to serve the Litchfield Correctional Center, a state-operated facility, were developed by the city through a private developer. Once the state completes payment of the developer's investment with interest -- over a perlod of 13 to 15 years -the city will assume ownership at no cost. The city and the developer are seeking industrial users for the cascaded energy from the system -now disposed of through a sprinkler system covering 11 acres - and any profits will be shared. The state benefits through reduced costs per therm of energy supplied. The minimum of 60 billion Btu's per year required by the state contract displaces approximately 500,000 gallons of the 750,000 gallons of fuel oil previously consumed. The system went on-1ine in November of 1983 and completed the first heating season successfully. 


\section{HAWAII}

\section{HAWAII TO BUID GEOTHERMAL RESEARCH FACILTY}

Development of a geotherma1 research faclitty in Hawali was given the "green light" In mid-1984 when Hawali's Governor George Arlyoshi approved Capital Improvement Project (CIP) funds of $\$ 325,000$. The Puna High Technology Facility (PHTF) w111 be constructed at the site of the highly successful HGP-A wellhead generator which has operated almost continuously since 1982 , proving the feasibility of producing electricity from Hawali's geothermal energy resource.

The facility will perform research, development, and demonstration of profects that will explore uses of geothermal energy and the byproducts of geothermal energy product1on. The research program will be the responsibility of the Hawail Natural Energy Institute in cooperation with the University of Hawail at H110. PHTF is expected to lead to construction of an industrial park and programs in multipurpose dehydration and bloconversion, which w111 provide jobs and tax revenues to stimulate the Puna area economy.

Source: Geothermal Resources Counc11 Bulletin 11/84

\section{IDAHO}

\section{LEAF LETTUCE COMES OFF ASSEMBLY LINE AT BRUNEAU GREENHOUSE}

A hydroponic leaf lettuce geothermally heated greenhouse owned by Thurman Black of Bruneau started to produce lettuce in September 1984. The lettuce is started in bottomless cups, transferred to styrofoam planks with roots extending into hydroponic fluids and floated through long con- tinuous tanks for harvesting at one end of the facility. It requires about eight weeks to produce a head of lettuce. After two weeks, 16,000 plants are transplanted at a time from the cups to the planks. After the planks reach the end of the tanks in six weeks, they are replanted and about 8000 heads per week go to market. The 25,000 square foot facility is heated by six $3000 \mathrm{Btu} / \mathrm{hr}$ air handling units producing $95^{\circ} \mathrm{F}$ air from $100^{\circ} \mathrm{F}$ geothermal water. An artesian well used for irrigation provides the water, which after heating the greenhouse, is returned to an irrigation ditch.

\section{Source: Oregon Institute of Technol-} ogy Geo-Heat Center

\section{HYDRA-CO ENTERPRISES BUYS DOE PROPERTIES AT RAFT RIVER}

Hydra-Co Enterprises, a whollyowned subsidiary of Nlagara Mohawk, established by the Syracuse, N.Y., utility to develop alternate energy sources, has been deeded the Raft River 5 MWe binary plant, wells, and 560 acres of federal land. After offering a high bid of $\$ 750,000$ for the Raft River facllity and the real property near Malta, Idaho, In a General Services Administration disposal sale, physical possession by Eydra-Co had been held up earller this year pending completion of a pro-forma Justice Department review to determine that no antitrust problems were created as a result of the sale.

Charles J. Muolo, Hydra-Co vice president for cogeneration development, said it is still up in the air as to whether the plant w111 be left at Raft River and its power sold locally, physically moved elsewhere, or sold to others, with the heat from the wells sold for direct use projects. These and other optlons are currently being examined. Idaho Power has filed a suit against the state PUC 
over avolded costs to be paid by the utility to PURPA producers, and the outcome of the legal battle would affect any decision of Hydra-Co to keep the binary plant where it is for local sales. (As of November 8, 1984, the litigation had not been resolved, and Hydra-Co still had made no decision on disposition of property.)

Source: Geothermal Report - 5/1/84

\section{NEVADA}

\section{NEVADA SENATOR CONVENES HEARING}

The status of geothermal development in Nevada was discussed at a oneday meeting in Reno in April 1984. Chaired by Governor Richard Bryan, convened by Senator Chic Hecht, and attended by 23 state, federal, and industry witnesses, problems were cited as belng: acreage limitations on federal lands, lease expiration after the 10-year primary term, expiration of energy investment tax credits, and IRS temperature limitation on geothermal reservoirs of $50^{\circ} \mathrm{C}\left(122^{\circ} \mathrm{F}\right)$ for tax deduction on cost of geothermal heating. Another hold-up in geothermal development is the difficulty in justifying development of geothermal by Sierra Pacific Power since its current capacity exceeds demand. However, Sierra Power does have arrangements for three pilot geothermal projects.

Source: Hearing before the House Subcommittee on Energy and Mineral Resources 4/17/84

\section{NEVADA LEGISLATURE EASES EXPORT OF ELECTRICITY}

The 1983 session of the Nevada legislature eased restrictions on the export of power generated in the state. In the past, producers of power with geothermal energy were required to:
- Make 50 percent of their production capacity avallable to utilities located within the area and within the state; or

- Permit those Nevada utilities to recapture up to 50 percent of production from out-of-state utilities that had contracted to purchase the electricity from the geothermal producers.

Under the new legislation; producers are only required to offer plant capacity to the local utility, and if the offer is declined, they may export the capacity to another state without further obligation.

This change will tend to encourage geothermal power development in Nevada since Sierra Pacific Power Co. does not need additional capacity at this time, and full capacity can be offered to the more lucrative California markets.

Source: Geothermal Hot Line 12/83

\section{POWER TRANSMISSION LNE FROM NEVADA TO CALIFORNIA IS FIRST TO BE BUILT BY NON-UTILTY OIL/GEOTHERMAL FIRM}

Sun 011 Co. filed an application with the Bureau of Land Management in June 1984 to construct a $140 \mathrm{MW}$ power transmission line from Dixle Valley, Nevada, to Bishop, California. Th1s is belleved to be the first transmission line constructed by a non-utility field operator. The project will tie Sun's Dixie Valley geothermal field into an existing $50 \mathrm{MW}$ Southern California Edison (SCE) power line in Bishop and allow Sun to tap the more profitable Los Angeles power market. A Sun official has announced that the company is talking with other geothermal developers at Dixie Valley and other locations along the transmission line about participating in the line. "We don't want to rule out anybody's participation," he sald. The locations 
could Include Beowawe, Brady Hot Springs, Steam Boat Springs, Desert Peak, and Fish Lake. Development is planned or under consideration at all of these locations. Sun also plans a 10 MWe plant at Dixie Valley.

It 1 s expected that the capacity of the $50 \mathrm{MW}$ SCE line will have to be upgraded as these areas are developed.

Sources: Geothermal Resources Counc1l Bulletin 7-8/1984

Geothermal Report 7/2/84

\section{NEW MEXICO}

\section{CONSTRUCTION TO START ON NMSU GREENHOUSE}

Collection of matching funds of $\$ 50,000$ from the greenhouse Industry was needed to release a state appropriation of $\$ 400,000$ for a geothermal greenhouse research facility on the campus of New Mexico State University at Las Cruces. Collection was completed In October 1984 by the New Mexico Energy Institute and immediate release of the funds by the state Energy Research and Development Institute and the University 18 expected. The 12,000 square foot greenhouse complex, the construction of wich will take about slx months, w111 demonstrate different geothermal heating oystems and greenhouse designs, with princ1pal research activities in floriculture and aquaculture. The project is Intended to trigger the establishment of a geothermally heated greenhouse industry in southern New Mexico.

A second well is under constructIon In the Las Cruces East Mesa Geothermal Field to serve the greenhouse and permit expansion of the campus. geothermal heating system which now serves about 30 bulldings. Fluld temperature of the first well is approximately $63^{\circ} \mathrm{C}\left(146^{\circ} \mathrm{F}\right)$ at about 800 feet.

\section{ACTIVITY ON INDUSTRIAL PARK DEVELOPMENT NEAR LAS CRUCES CONTINUES}

Crown Geothermal Ltd., formerly Chaffee Geothermal, is targeting agribusiness for this proposed geothermal Industrial park that will be located near the New Mexico State University campus heating project. The resource has been defined, wth wells producIng $60-71^{\circ} \mathrm{C}\left(140-160^{\circ} \mathrm{F}\right)$ waters flowing 1000 to $2500 \mathrm{gpm}$ per well. The State's Energy and Minerals Department is assisting in the search for financing the project which is in an excellent location.

Source: Idaho National Engineering Laboratory Reglonal Progress Monitor $6 / 84$

\section{NMERDI RECIEVES GRANT FOR EXPLORATION WORK}

The New Mexico Energy Research and Development Institute requested proposals to explore for electricalgrade geothermal reservolrs, moderate to intermediate temperature reservotirs, and for programs based on temperature gradient drilling to locate sites for deeper drilling. The request was in response to a $\$ 90,000$ grant to the state from the U.S. Department of Energy to explore for geothermal sites in New Mexico. The deadiline for proposals was November 5.

Source: PI National Geothermal Service $9 / 28 / 84$

\section{PRAWN FACILITY UNDER INVESTIGATION FOR HIDALGO COUNTY}

HIdalgo Energy Enterprises, Inc. Is looktng at a possible joint venture wth an Israeli firm to develop a prawn farm in Hidalgo County, New Mexico. The developers are also considering binary power generation to meet facility needs. The specific site has not been selected. 
Source: Idaho National Engineering Laboratory Regional Progress Monitor $6 / 84$

\section{GREENHOUSE WORK CONTINUES NEAR}

\section{ANIMAS}

A geothermal greenhouse facility is developing near Animas in Hidalgo County, New Mexico, for the production of roses. Tom Beal, the developer who relocated to the area from the State of Washington, has been assisted by the State's Energy and. Mineral Department which provided matching funds $(\$ 75,000)$ through a 1982 appropriation for geothermal development. Major construction activity started in January 1984, resulting in erection of one 24,000 square foot facility containing about 15,000 roses. Another similar sized unit is planned for the near future. One geothermal production well has been drilled and will be hooked into the system that is expected to be operational for the 1984-1985 heating season. Other unique features include fog nozzle watering and solar film glass applications.

Source: Idaho National Engineering Laboratory Reglonal Progress Monitor $6 / 84$

\section{NEW YORK}

\section{NY STATE SCHOOLS HEATED BY GEOTHERMAL WEL}

A direct use project has been undertaken to tap hot water from a nearby geothermal well to heat the Cayuga County Community College and the East Middle School in Auburn, New York. The mile-deep well, located in an athletic fleld of the East Middle School, is capable of pumping $100 \mathrm{gpm}$ of $52^{\circ} \mathrm{C}\left(125^{\circ} \mathrm{F}\right)$ water.

Major funding for the project is provided by a $\$ 750,000$ grant from the
U.S. Department of Energy; the two cosponsors are the New York state Energy Research and Development Agency (NYSERDA) and the Empire State Electric Energy Research Corporation.

The project serves as a pilot program to demonstrate the technology and costs involved in the utilization of geothermal energy in New York state. It is the only project of its kind. In the northeastern United States.

Source: Geothermal Resources Council Bulletin 6/84

\section{OREGON}

\section{NEWBERRY CRATER DEVELOPMENT TO BE CONSIDERED BY SITING COUNCIL}

The Oregon Facility Siting Council, with jurisdiction over projects exceeding $25 \mathrm{MW}$, received a briefing in August 1984 by Industry, Oregon Department of Energy, and the U.S. Forest Service on the status of development for the Newberry Crater area. Subsequent to the briefing, a formal motion was made and accepted to examine the suitability/unsultability of the use designation of lands within the state.

Source: Idaho National Engineering Laboratory Regional Geothermal Progress Monitor 7/84

\section{BREITENBUSH EXPANSION ASSESSED}

The Oregon Department of Energy, DOGAMI, and Water Resource Department are gathering and assessing well and spring data from three land parcels in the Breltenbush Hot Springs area. Significant expansion of utilization of geothermal energy on two of the parcels is being considered, and the proposed development is before the County Planning Commission. 
Source: Idaho National Engineering Laboratory Regional Geothermal Progress Monitor

\section{DEVELOPMENT PLAN FOR DESCHUTES COUNTY PREPARED}

Ellot Allen and Associates have prepared a development plan for the Deschutes, Oregon, County Planning Commission. Union 011 has volced objection to the plan on the basis of its "middle-of-the-road" approach. Action on the plan is pending for the environmentally concerned county that contains such prime geothermal areas as the Three Sisters, Newberry Crater, and Mt. Batchelor.

Source: Idaho National Engineering Laboratory Regional Geothermal Progress Monitor 7/84

\section{LAKEVIEW WELHEAD GENERATORS OPERATED FOR SITING COUNCIL}

The Lakeview binary system wellhead generators were operated for a few hours on June 28, 1984 for the Oregon Energy Facility Siting Council. Although the council is responsible for facilities over $25 \mathrm{MW}$, its interest in the technology of the 1 MW Installation occasioned the plant operation. PUC approval, installation of a cooling tower, and a long-term well test are needed to finalize the project.

Source: Idaho National Engineering Laboratory Regional Geothermal Progress Monitor 6/84

\section{GEOTHERMAL ADVISORY COMMITTEE ORGANIZED FOR KLAMATH FALLS}

A committee has been created to advise appropriate governing bodies and developers on all matters concerning geothermal resources in Klamath County. It w111 propose safeguards adequate to protect existing use, pose a gradual development plan for the unused resource potential, recommend priorities of use, oversee and maintain continued long-term well monitoring and inventory, and provide a community resource information center. The committee is made up of a cross section of the community through representation of citizen groups and local, state, and federal government agencies. Paul Lienau, OIT Geo-Heat Center, was elected Chafrman. The committee has recommended staging the expansion of the Klamath Falls district heating system.

Source: Idaho National Englneering Laboratory Regional Geothermal Progress Monitor 6/84

\section{UTAH}

\section{UTAH GEOTHERMAL HOT HOUSE REALIZES} LARGE SAVINGS IN FUEL COSTS

Utah Roses, a wholesale rose grower-distributor that ships by air nationwide from Salt Lake City, reports the success of two large commercial geothermal greenhouses. Greenhouse Unit \#1, six-acres under glass, cost $\$ 690,000$ and produces 180 $\mathrm{gpm}$ of $50.5^{\circ} \mathrm{C}\left(123^{\circ} \mathrm{F}\right)$ water with a 100 hp pump. Th1s provides 45 percent of the annual heat requirement, saving $\$ 84,000$ per year even with Utah's low natural gas costs. Greenhouse Unit $\$ 2$, located on a 3-acre complex 20 miles from the airport, operates on a $88^{\circ} \mathrm{C}\left(190^{\circ} \mathrm{F}\right)$ well with a 30 hp pump which provides 100 percent of the heat needed. This unit cost $\$ 90,000$ (including wells) and provides a net savings of $\$ 100,000$ per year.

Source: The Geyser $9 / 84$ 


\section{WASHINGTON}

\section{BPA LOOKS AT GEOTHERMAL POWER POTENTIAL OF PACIFIC NORTHWEST}

The states of Idaho, Oregon, Montana, and Washington have been selected by the Bonneville Power Administration for a study to identify the best sites for geothermal energy development in the Pacific Northwest. BPA will use the study results to assess geothermal potential to meet area power needs, to evaluate proposed demonstration projects in electricity production, and to develop electric power conservation programs using geothermal heat. The project is part of the Northwest Power Planning Council's two-year "action plan," under which BPA intends to buy power from geothermal production at a level of at least 10 megawatts of electricity. Water and space heating sites also w111 be considered. Targeting geothermal hotspots in the Cascade Range, and central Idaho, BPA's 18 month study will specify the best places for further research and deve1opment. (EDITOR'S NOTE: This study has been completed and published.)

Private industry also continues to examine geothermal possibilities In the area. Seattle City Light is studying sites near Mt. Baker, and California Energy is Investigating possibllities in the Crater Lake region of southern Oregon.

Source: Geothermal Report 12/15/83 
While the stated purpose of the Renewable Energy Development Act of 1983 is to facilitate "the overall abilities of the domestic renewable Industry and related service Industries to create new markets," the primary emphasis is currently on forelgn markets, with special attention given to marketing to developing nations. The announced goal of an Interagency Working Group created by the Act is to Increase the efficiency of the federal government's ability to provide renewable energy export assistance "so that our renewable energy industry maintains or strengthens Its world leadership position.".

The Secretary of Energy will chair the Group. Other member agencles have major responsibilities for international trade - e.g., the Agency for International Development and the ExportImport Bank. The Department of Commerce and the Small Business Administration are also members by virtue of their programs to assist businesses in entering international markets.

The federal governent of fers over 100 programs that can assist geothermal firms in exporting hardware or services. The function of the WorkIng Group is to make recommendations for coordinating these programs to serve the purposes of the Act, which also calls for consultation with industry groups.

The Commerce Department w111 soon complete the assessments mandated by the Act:

- of the technical and commercial status of the U.S. renewable energy Industry and related service Industries in domestic and foreign markets.

- of federal activities affect- ing conmerce in the renewable energy industry and related service industries.

- of the improvements that must be made to increase the international commercialization of the industry and related service industries.

The emphasis on "related service industries". Is particularly important to the U.S. geothermal industry with its experience in geothermal exploration, driling, power plant operation, and the other expertise it can provide, and is providing, abroad.

For information on the progress of the Working Group or to of fer to provide Information to it, contact: Robert H. Annan, Director, Photovoltalcs Energy Technology Division, U.S. Department of Energy, 1000 Independence Avenue, S.W., Washington, D.C. 20585, (202) 252-1720. For information on the Commerce Department activities or publications, contact: Leslie Garden, U.S. Department of Commerce, 14th Street \& Constitution Avenue, N.W., Washington, D.C. 20230, (202) 377-0556.

\section{BRITISH RESUME HOT DRY ROCK RESEARCH}

In an attempt to improve the reservolr connection at the Rosemanowes Quarry hot dry rock test site, the British have commenced drilling a third well. While the project, Initiated in 1979, previously successfully achieved an interconnection between the first two wells, the hydraulic connection was poor, causing flow impedance and water loss. Only about 60 percent of the injected water was recovered compared to 95 percent recovery at the DOE Fenton H111, New Mexico, hot dry rock experimental site. 
The third well will be deviated at a different angle into the fracture, which, it is anticipated, will complete a high rate/high pressure closed loop circulation system. Drilling will be completed in early December 1984 and wili be followed by reservoir evaluation tests. If the tests are successful, six months of heat extraction wili be conducted during 1985 .

A spokesman for the Los Alamos National Laboratory at Albuquerque, which conceived of and conducts the Fenton Hill experiments, noted the differences between the British and U.S. experiments. In brief, they Include the British use of explosive fracturing ahead of hydraulic fracturing, more intensive rock mechanisms studies, shallower fractures, and lower temperatures.

Source: Los Alamos National Laboratory

\section{ITALY STEPPING UP GEOTHEPMAL DEVELOPMENT}

After a period of inactivity in geothermal development, the Italians are launching ambitious plans for geothermal power generation and hope to reach 600 to 800 MWe by 1990 . Existing Installed capacity is 450 MWe. New high-temperature fields near Lardere1lo have been discovered, or further refined, and the entire length of the Apennines 18 being explored and/or developed, from Larderello in the north to Naples in the south. Low-temperature development is also taking place in the Po River plain. The older fields, primarily In Tuscany, are operated by ENEL, the state power agency, but the newer fields are being developed jointly by ENEL and AGIP, the state oll company.

Source: Geothermal Report 8/1/84

\section{CHINA INCREASING GEOTHERMAL CAPACITY}

The People's Republic of China has announced plans to more than double its present production of electricity from geothermal energy by 1990. Five 3 MWe generators are to be installed at Yangbajain geothermal station near Lhasa in the Tibet Autonomous Region. These will be jolning the present 7 MW capacity at Yangbajain. Another $3 \mathrm{MW}$ station is planned near Ali to supply power to Shiquanhe township in western Tibet. The Ministry of Geology, which has responsibility for geothermal exploration, has also Identifled several direct use projects including a large district heating system in the southeast part of Beijing (Peking).

Source: 011 and Gas Journal 9/10/84

\section{SECOND UNIT UNDER CONSTRUCTION AT MOTOTUMBO, NICARAGUA}

The Micaraguan Institute of Energy has contracted with the Society of Exploration and Geothermal Studies of Argenteul1 (France) for management and equipment procurement for the drilling of four development wells at the Mototumbo geothermal field. The contract is estimated at about $\$ 3.5$ million and is financed through a loan guaranteed by the French government. The four wells will provide a portion of the fluid for the second 35 MW unit at Mototumbo. Unit 1 went on-line in August 1983.

Source: Geothermal Resources Counc1l Bulletin 1/84

\section{EXPLORATION INITIATED IN NORTH YEMEN}

As a follow on to World Bank supported survey work, the Yemen Arab Republic (North Yemen) will be drilling four exploratory wells (approx. 6500 ft.) to define the extent of the geothermal reserves in the southeast- 
ern Dhamar-Rada's region. A $\$ 13$ million loan from the International Development Assoclation of the World Bank plus $\$ 2.4$ million from the Yemen government will finance the project. Technical assistance and training, both locally and abroad, are also included.

Sources: World Bank Annual Report 1984 011 \& Gas Journal 6/11/84

\section{DRIUUNG ACTIVITIES ACCELERATING IN SOVIET UNION}

The Soviet Union has begun its hot dry rock experimental programs with the drilling of a 13,000-foot well in the western Ukraine. Bottom hole temperature is approximately $200^{\circ} \mathrm{C}\left(400^{\circ} \mathrm{F}\right)$. The second will be drilled shortly. The first stage of the project will be the construction of a small experimental generator (approximately $1 \mathrm{kw}$ ), to be expanded if tests are successful.

In other news, the Soviet deep hole on the Kola Peninsula is reportedly approaching 42,650 feet. The well was spudded in May 1970 and plans call for target depth of 49,200 feet by 1990 .

The deep hole at Saatly, Azerbaljan, also scheduled to over 49,000 feet, apparently has made Ifttle progress since it reached 26,837 feet in August 1982. Reports refer to an "accident" for which solu$t$ ions have not been found. The well was spudded In June 1977.

Work has also started on two more super-deep tests, near Poltava, Ukraine, and in western Siberia.. Preparations have been made for drillIng seven more deep. scientific wells in the Soviet Union.

Sources: Oil and Gas Journal 7/23/84 011 and Gas Journal 7/2/84

\section{WILDCAT WELLS UNDERWAY IN KENYA}

Kenya is accelerating its exploration for geothermal energy with a $\$ 245$ million dollar loan from the InternatIonal Development Association of the World Bank. The primary effort will be the drilling of 20 wildcat wells in the Eburru and 0lkaria regions to define the areas with the best prospects for future steam development. Two 15 MWe generating units are already in operation at the 01karia field, and a third is expected to go on-line in March 1985.

Sources: World Bank Annual Report 1984

011 and Gas Journal 6/18/85

\section{INDONESIA EXPANDS KAMOJANG STATION}

The Indonesia Electricity AuthorIty has contracted with Mitsubish1 for the delivery of two $55 \mathrm{MW}$ geothermal power plants for its Kamojang station; near Bandany in Java; Indonesia. Total contract is valued at about $\$ 20.35$ million, to be financed by the International Bank for Reconstruction and Development. Delivery of the units is scheduled for July 1987 and November 1987.

Source: 011 and Gas Journal $9 / 17 / 84$

\section{EXPLORATION BEGINS IN EAST AFRICA}

The country of Djibout1, East Africa, has begun a three-year project for the exploration of Its geothermal resources. Th1s will include the drilling of test wells to determine if commerclally exploitable geothermal reserves exist in the country. The project is reportedly co-financed through the International Development Association ( $\$ 6$ million), the African Development. Bank ( $\$ 2.4$ 
million), OPEC ( $\$ 1$ million), and the UN Development Program ( $\$ 1$ million). Aid includes technical assistance to the country's geothermal research institute.

Source: World Bank Annual Report 1984

\section{UNITED NATIONS HOLDS GEOTHERMAL CONFERENCE}

The United Nations Economic Commission for Europe sponsored a conference on Utilization of Geothermal Energy for Electric Power Production and Space Heating in Florence, Italy, May 14-18, 1984. Of the approximately 100 attendees, few were from Iron Curtain countries.

Considerable emphasis was placed on electricity generation and statistics presented indicate that in 1960 the worldwide geothermal capacity was $375 \mathrm{MW}$. This increased to $2800 \mathrm{MW}$ by 1982 ( 940 in U.S. and 450 in Italy), and is projected to increase to 5500 MW in 1986. Worldwide, most turbine/ generator units are $30 \mathrm{MW}$ or less, but The Geysers claims the largest, $135 \mathrm{MW}$.

Source: Geothermal Report 8/1/84

\section{MEXICAN GEOTHERMAL POWER TO BE EXPORTED TO U.S.}

The San Diego Gas and Electric Co. has contracted to buy power from the Cerro Prieto generating plant just over the California border in Mexico. The purchase covers the 110 MWe output of a new plant at the facility that came on-line in September, 1984. Purchase price was $\$ 90$ million. The amount of power transmitted will be increased as new capacity is operational at Cerro Prieto.

The Mexican government, owner of the plant, constructed a four-mile transmission line to the border, and SDG\&E connected with a 230 kilowatt five-mile line to hook into the Southwest Powerlink. At a cost of 4.5 cents per kilowatt hour compared with the six cents SDG\&E pays for electricity generated with coal and natural gas, the arrangement is expected to save the utility as much as \$233 million in operating costs over the next 10 years.

Sources: Geothermal Resources Counc11 Bulletin 1/84 The Oil Dafly $9 / 14 / 84$

\section{AIR FORCE PLANS FOR GEOTHERMAL POWER FOR ASCENSION ISLAND}

The U.S. AIr Force plans to develop a geothermal power plant to serve its leased air base on Britsh-owned Ascension Island. Following exploration on the island by the Idaho National Engineering Laboratory and the University of Utah Research Institute, DOE's Idaho Operations Office has proposed drilling a deep well to confirm the resource. The Air Force will ask for $\$ 16$ million in 1 ts fiscal 1986 budget request to complete the well and build the plant.

The Air Force would also use the geothermal project to produce fresh water. The island has no natural fresh water supplies and both fresh water and electricity are now produced by burning oil to generate power and dist111 water. Project researchers calculate that the geothermal development will have a four-year payback period.

Sources: The Energy Datly $9 / 28 / 84$

U.S. Department of Energy

\section{MEXICO AIMING FOR 2440 MWE BY 2000}

Geothermal reserves in Mexico have been estimated at 1340 MWe proven, 4600 MWe probable, and 6000 MWe 
possible, for a total of $11,940 \mathrm{MW}$. In light of this assessment and the need to incorporate an ever-growing volume of geothermo-electric power into the Mexican system, the following schedule for incremental growth is planned for Cerro Prieto: Besides the $180 \mathrm{MWe}$ now in operation, an additional 440 MWe by 1985 generated by two plants of $220 \mathrm{MW}$ each; for 1992 , 220 MWe supplied by four power plants with a capacity of $55 \mathrm{MW}$. This w111 provide a total of $840 \mathrm{MW}$.

Planned construction at Los Azufres, where five 5 wiWe wellhead generators have been in operation since 1982 , Is as follows: 50 MWe plant for operation in December 1986; two 55 MWe plants in operation by the end of 1988 and 1989; and construction started on a third 55 MWe plant around the middle of 1990. In addition, seven additional 5 MW portable units will be installed in 1986-87 and an additional 10 between 1992 and 1993 .

At Los Humeros, three 5 wWe units will be installed in 1987, and in 1990 and 1991 construction w111 begin on two 55 MWe plants.

Mexico hopes to reach a total capacity of 2440 MWe by the year 2000 .

Source: Hector Alonso Esplnosa, "Geothermics, An Alternate Energy Source for Power Generation." Presented at the Geothermal Technology Conference, October 1984. 


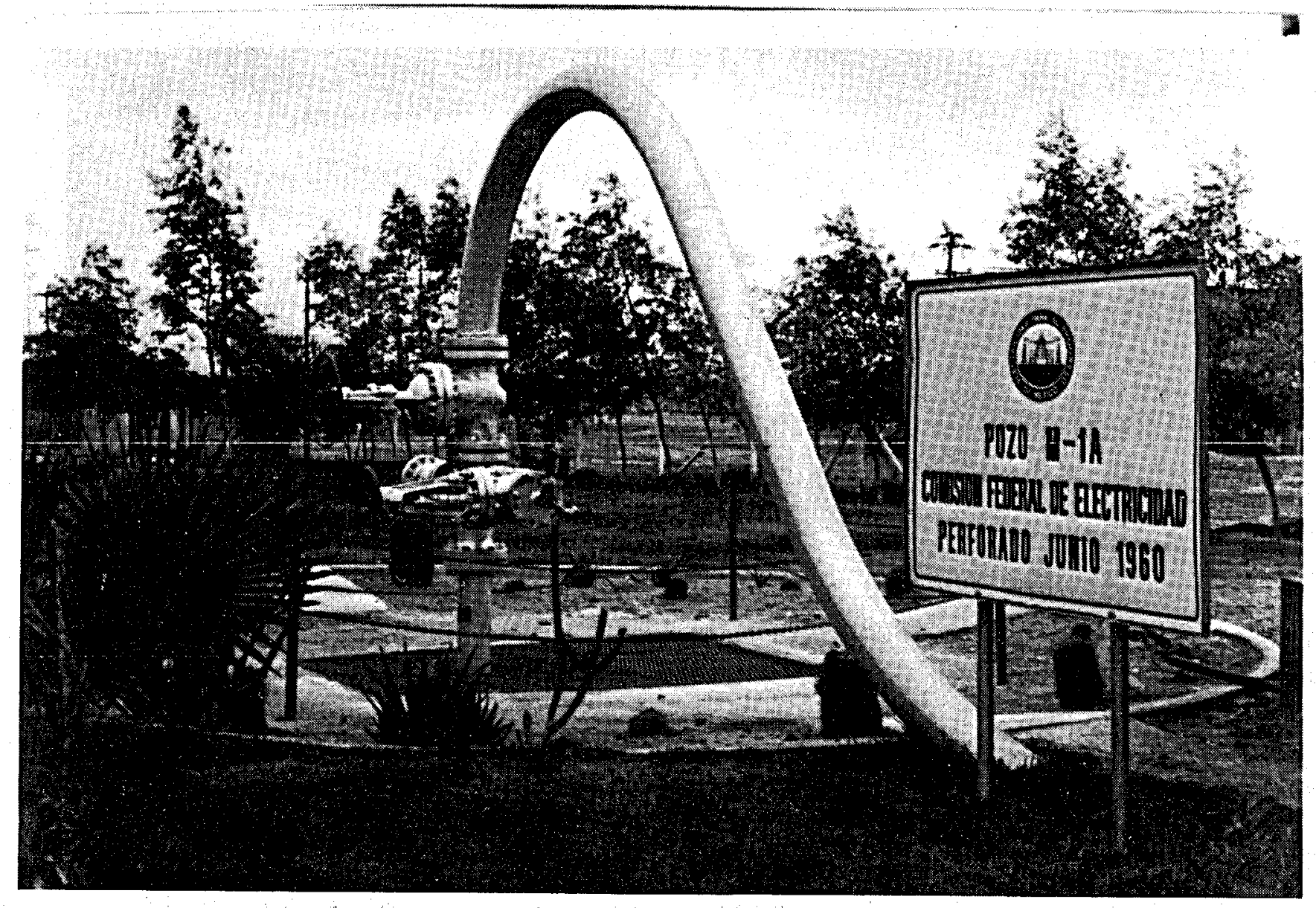

Geothermal well at Cerro Prieto, Mexico, Drilled in June 1960. 
FOREST SERVICE HELD GEOTHERMAL WORKSHOPS FOR FIELD PERSONNEL

A Special Workshop on Geothermal Energy, which included field trips, was held by the U.S. Forest Service In Cedar City, Utah, October 10-12, 1984. An identical session was held in Oakland, California, November 1315. The program announcement noted that the workshops were designed to answer personnel questions on matters concerning geothermal planning, regulations, drilling, and other related subjects. The Forest Service's new mineral potential assessment ef fort was high on the list of topics to be covered.

\section{TECHNOLOGY TRANSFER WORKSHOP HELD BY DOE FOR FEDERAL PROGRAM MANAGERS}

A two and one-half day workshop entitled "A Synthesis of Technology Transfer Methodologies," sponsored by the Department of Energy, was held on May 30,31 , and June 1, 1984 in Washington, D.C. The objective of the workshop was to refamiliarize current federal program managers with the approaches to technology transfer taken by previous programs during the $1960^{\prime} \mathrm{s}$ and 170's. The combined exper1ence of past technology transfer programs by the National Aeronautics and Space Administration, the National Sclence Foundation, the Department of Commerce, and DOE would enable technology transfer planners to become more aware of the opportunities and obstacles facing them, and to design more effective and realistic programs.

The workshop, w1th attendance of 100, addressed a broad range of technology transfer issues, including technology transfer definition, administra$t$ Ive concerns, evaluation and effectiveness, barriers to communication, and mechanism selection. Specific program histories were scrutinized for guidance and "lessons learned."
In addition, an expert panel answered attendee questions.

\section{PIO GRANDE RIFT ATLAS: 10-YEAR PROJECT UNDERWAY}

A major endeavor to produce an atlas of the RIo Grande rift has been undertaken by a team of Southwest geoscientists from Los Alamos National Laboratory, the U.S. Geological Survey, the New Mexico Bureau of Mines and Mineral Resources, and regional universities. The Rio Grande rift is a North American tectonic region rich in natural resources that extends from Colorado through New Mexico and west to Northern Mexico. The project is headed by the Rio Grande Rift Consortium, formed in 1982 to promote research on the rift.

The atlas w111 include aeromagnetic and gravity maps, information on topography, geology, crustal structure, young faults, and the composition and age of volcanic rocks.

Source: Geothermal Resources Council Bulletin 4/84

\section{GEOTHERMAL STUDY OF SOUTHEASTERN WYOMING BASINS AVAILABLE}

Geothermal resources in the Laramie, Hanna, and ShIrley basIns of southeastern Wyoming are discussed In a report recently published by the Geological Survey of Wyoming. The report is the first of six to result from a five-year study through the University of Wyoming 's Department of Geology and Geophysics. The study made use of oil well bot tomhole temperatures, thermal logs of wells and heat flow data, all within the framework of geological and hydrological Information, to determine the geothermal regimes in the basins and to predict where the state's potential geothermal resources exist. 
The 26-page report, "Geothermal Resources of the Laramie, Hanna, and Shirley Basins, Wyoming," includes four folded map sheets. The report is available as Report of Investigations No. 26 from the Geological Survey of Wyoming, Box 3008, University Station, Laramie, WY 82701. The Survey phone number is (307) 766-2286.

Source: PI National Geothermal Service $7 / 27 / 84$

\section{BOOKLET HGHUCHTS NM'S GEOTHERMAL} POTENTIAL

New Mexico's geothermal energy resources and the potential use of these resources are summarized in a new publication, "Geothermal Resources of New Mexico," by Arlene H. Starkey. and Larry Icerman. The booklet addresses several topics: resource areas; development activities; institutional issues involved in using geothermal resources; low-temperature geothermal heating and electrical generating systems; and active low temperature development programs. A bibliography is included.

The booklet emphasizes that 21 potential sites for commercial geothermal energy development have already been Identified in New Mexico, and additional areas of the state may be suitable for geothermal resource exploration.

The booklet can be obtained from the New Mexico State University Energy Institute, Box 3E1, Las Cruces, NM 88003, telephone (505) 646-1745, or from the New Mexico Energy Research and Development Institute Information Center, Suite M, 457 Washington SE, Albuquerque, NM 87108, telephone (505) 277-3661.

Source: Geothermal Resources Council Bulletin 5/84

\section{NEW DATA RELEASED ON KLAMATH} FALLS AQUIFER

A seven-week pumping and injection test in the geothermal aquifer at Klamath Falls, Oregon, during the summer of $1983,1 \mathrm{~s}$ the subject of a new report on the hydraulic properties of this area.

The report contains graphs of water levels measured in 50 wells located in a 1.7 square mile section of the hot-well area of Klamath Falls. Also Included are temperature measurements in 17 wells; dally alr-temperature in relation to discharge of thermal water from more than 70 pumped and arteslan wells; tables of monthly mean alr temperature and estimates of thermal water during a normal year; and tables of chemical and Isotopic analyses on samples from 12 wells.

The report, authored by S.M. Benson and others, is entitled "Data From Pumping and Infection Tests and Chemical Sampling in the Geothermal Aquifer at Klamath Falls, Oregon." It is 1isted as Open-File Report 84146 and can be obtalned for $\$ 14.25$ per paper copy from the Open-File Services Section, U.S. Geological Survey, Western Branch of Distribution, P.0. Box 25425, Federal Center, Denver, Co 80225.

Source: Geothermal Resources Counc1l Bulletin 5/84

\section{GRC FIRST ABSTRACT SET}

Special Report No. 14, Geothermal Energy Abstract Sets, was issued by the Geothermal Resources Council. The document contains the first three sets of abstracts that are part of a set of 12 being compiled by the GRC under a U.S. DOE grant. Selected abstracts on case histories, drilling, 
and reservoir englneering are covered In the first document. Contact the GRC at P.0. Box 1350, Dav1s, CA 95617, telephone (916) 758-2360 for more information.

$4:$

Source: Idaho National Engineering Laboratory Regional Geothermal Progress Monitor 9/84

\section{"HEATPLAN" AVAILABLE IN WASHINGTON STATE}

The Washington State Energy office is making avallable for use by local planning of ficials a set of guidelines for determining the feastbilfty of Installing a geothermal district heating system. The "HEATPLAN" is a microcomputer program designed to provide a neighborhoodlevel inventory of community heat demands by type of land use. It also provides preliminary assessment of geothermal district heating "favorabilitles" for neighborhoods.

Copies can be obtalned from Gordon Bloomquist, Geothermal Special1st, WA State Energy Office, $400 \mathrm{E}$. Union Street, Olympla, WA 98504.

Source: Geothermal Report 4/2/82 
JANUARY 1985

Office of Energy Research, U.S. National Committee on Scientific Hydrology, International Congress on Hydrology of Rocks of Low Permeability, Tucson, AZ, Jan. 7-12.

Cooling Tower Institute, Annual Technical Meeting, New Orleans, LA, Jan. 21-23.

Stanford University, 10th Annual Workshop on Geothermal Reservoir Engineering, Stanford, CA, Jan. 22-25.

\section{FEBRUARY 1985}

Institut Francais de Petrole, Center National de la Recherche Scientifique, et al, Symposium on Geodynamics of the Caribbean, Paris, France, Feb. 5-7.

American Society of Mechanical Englneers, et al, Eighth Energy-Sources Technology Conference and Exhibition, Dallas, TX, Feb. 18-20.

Purdue University, 24th Annual Corrosion Short Course, West Lafayette, IN, Feb. 20-21.

\section{MARCH 1985}

Battelle Columbus Laboratories, Alternative Generation Technologies Conference and Tour, Long Beach, CA, March 4-8.

Exposition on Energy Technology, 12th Conference, Washington, DC, March 25-27.

American Institute of Chemical Engineers, Petro Expo 85 and AICHE's Spring National Meeting, Houston, TX, March 25-28.

National Association of Corrosion Engineers, Annual Conference, Corrosion/ 85, Boston, MA, March 25-29.

\section{MAY 1985}

American Society of Civil Engineers, Spring Convention, Denver, Co, May 13-17.

JUNE 1985

British Hydromechanics Research Association, Second International Conference on Multiphase Flow, Kensington Close Hote1, London, England, June 19-21. 
Geothermal Resources Council, Workshop on Drilling of High Temperature Geothermal Wells, Kailua-Kona, HI, Aug. 23-25.

Geothermal Resources Council, International Symposium on Geothermal Energy, Kallua-Kona, HI, Aug . 26-30.

Geothermal Resources Council Course on Fractures in Geothermal Reservoirs, Kallua-Kona, HI, Aug. 31-Sept. 1 .

\section{OCTOBER 1985}

Society of Exploration Geophysicists Annual International Meeting, Washington, DC, Oct. 20-24.

American Society of Civil Engineers, Annual Convention and Exhibition, Detro1t, MI, Oct. 21-25.

Association of Energy Engineers, 8th World Energy Englneering Congress, Atlanta, GA, Oct. 22-27.

Geological Society of America, Annual Meeting, Orlando, FL, Oct. 28-31.

\section{DECEMBER 1985}

Clean Energy Research Institute, 7th Miam1 International Conference on Alternative Energy Sources, Miam1 Beach, FL, Dec. 9-11.

Geothermal Research Soclety of Japan, Annual Meeting, Kyushu University, Fukuoka, Japan, Dec. 4-6.

\section{AUGUST 1986}

Circum - Paciflc Energy and Mineral Resources Conference, Singapore, Aug. 17-22.

NOVEMBER 1986

Geological Soclety of America, Annual Meeting, San Antonio, TX, Nov . 10-13.

\section{OCTOBER 1987}

Geological Society of America, Annual Meeting, Phoenix, AZ, Oct. 26-29. 


\section{GEOTHERMAL ENERGY}

Appropriate Technology Management Information System, DOE National Center for Appropriate Technology, Butte, MT, DOE/CE/15095-14, GPO DE 84010952 (Feb. 1984).

Directory of UK Suppliers and Supplies In Renewable Energy, University College, Cardiff, Wales (1983).

Transactions of the American Nuclear Society, Winter Meeting, San Francisco, CA (Oct. 1983).

Webb, J.W., et al., "Retrospective Examination of Geothermal Environmental Assessments," Oak Ridge National Laboratory, ORNL/TM-9071 (March 1984).

\section{GEOTHERMAL ENGINEERING}

Conrad, R.K., et al., "Corrosion of Selected Metals and a High-Temperature Thermoplastic in Hypersaline Geothermal Brine, Rept. of Investigations, 1983," Bureau of Mines, NTIS, PB-84-113547 (Sept. 1983).

Dreesen, D.S., et al., "Insulating Geothermal Well Casings from Thermal Stress with Nitrogen Gas or Nitrogen Foam," Los Alamos National Laboratory; Arizona University Well Production Testing, Carlsbad, CA, NTIS, LA-UR-841182, GPO DE 84011338 (Aug. 1984).

Finger, J.T., Program for the Improvement of Downhole Drilling Motors, Sandia National Laboratories, NTIS, SAND-83-0130, GPO DE 84005063 (Nov. 1983).

Hanold, R.J., Geothermal Pumping Systems, Los Alamos National Laboratory, NTIS, LA-UR-83-3071, GPO DE 84001728 (1983).

Htun, K.M., Materials Compatibility with the Volcanic Enviroment, Final Report, Hawaii University Department of Mechanical Engineering, NTIS, DOE/DP/00563-1, GPO DE 84010524 (March 1984).

Johnson, V.E., Jr., et al., Research and Development of Improved Cavitating Jets for Deep-Hole Drilling, Hydronautics, Inc., Laurel, MD (Jan. 1984).

Katagle, K., and W.K. Ott, "Frac Treatment Boosts Geothermal Well Production," Japan Metals and Chemicals Co., Ltd., Tokyo, World 011, 197; No. 4 (Sept. 1983).

Kelsey, J.R., and A.D. Allen, Geothermal Drilling and Completion Research and Development Program, Sandia Nat1onal Laboratorles, NTIS, SAND-83-1095C, GPO DE 84001647 (1983).

Nicholson, R.W., et al., Improvement of Tubulars Used for Fracturing in Hot Dry Rock Wells, Well Production Testing, Carlsbad, CA; Los Alamos National Laboratory, NTIS, LA-UR-84-1192, GPO DE 84011349 (Apr11 1984). 
Pett1t, R.A., and J.C. Rowley, "Geothermal Cement: High Temperature Downhole Tests: Continuation of an API Project," Los Alamos National Laboratory, Geotherma1 Resources Counc11 Bullet1n, 12; No. 8 (Aug. 1983).

Republic Geothermal, Inc., Geothermal Reservoir Well StImulation Program, Final Program Summary Report, Santa Fe Springs, CA, GPO DE 84008264 (Jan. 1984).

Robertus, R.J., et al., Report on Design, Construction, and Testing of $\mathrm{CO}_{2}$ Breakout System for Geothermal Brines, Pacific Northwest Laboratory, NTIS, PNL-5042, GPO DE 84010241 (March 1984).

Rowcliff; D.J., Development of a New Family of Cemented Carbides for Geothermal Drilling, Final Report, SRI International, Menlo Park, CA, NTIS, SAND-83-7435, GPO DE 84003148 (Oct. 1983).

Sutton, D.L., et al., "New Cement Handles Both High Temperature, Lost Circulation, Halliburton Services," Duncan, OK, World 011, 196; No. 5 (April 1983).

\section{GEOTHERMAL EXPLORATION AND EXPLORATION TECHNOLOGY}

Arney, Barbara H., et al,, editors, "Petrographlc Analysis and Correlation of Volcanic Rocks in 1-A We11, Near Mountaln Home, Idaho," National Technical Information Service, 5285 Port Royal Road, Springfield, VA 22161 (Apr11 1984).

Bell, John, W., "Quaternary. Fault Map of Nevada -- Reno Sheet," Nevada Bureau of Mlnes, University of Nevada, Reno, NV 89557-0088 (Apri1 1984).

Campbe11, M.D., "Dixie Valley, Nevada: A Promising Geothermal Area Under Development by Industry," Houston, TX; Proceedings, Intersoclety Energy Conversion Englneering, Orlando, FL (Aug. 1983).

Chang, H.T., et al., Evaluation of Borehole Electromagnetic and Se1smic Detection of Fractures, Sandis National Laboratories and Southwest Research Institute, San Antonio, TX, NTIS, SAND-84-7109, GPO DE 84009507 (Feb. 1984).

Chang, H.T., and L. Scott, Development of a Borehole Directional Antenna at VHF, Sandia National Laboratories, NTIS, SAND-84-0254, GPO DE 84010746 (March 1984).

De La Fosse, et al., "Development of Improved High Temperature Seals and Lubricants for Downhole Motors in Geothermal Applications," Drilling Research Laboratory, Salt Lake C1ty, Paper, Amerlcan Soc1ety of Mechanlcal Engineers," 83-PET-23 (Sept. 1983).

Ershag1, I., et al., "Estimation of Geothermal Brine V1scosity," University of Southern California, Journal of Petroleum Technology (March 1983).

Fox, D.J., Hydrothermal Alteration In Well Baca 22, Baca Geothermal Area, Valles Caldera, New Mexico, Lawrence Berkeley Laboratory (LBL-16883), NTIS, LBL-16883, GPO DE 84007441 (Jan. 1984). 
Gudmundsson, J.S., et al., "Streamtube Relative Permeability Functions for Flashing Steam-Water Flow in Fractures," Stanford University, Paper, Soclety of Petroleum Engineers of AIME (March 1983).

Korosec, M.A., et al., Low Temperature Geothermal Resources of Eastern Washington, Department of Natural Resources, Olympia, WA, NTIS, DOE/ET/27014T6 (Aug. 1983).

Lippmann, M.J., et al., "Exploration and Development of the Cerro Prieto Geothermal Field," Lawrence Berkeley Laboratory, Paper, Soclety of Petroleum Engineers of AIME, SPE 12098 (Oct. 1983).

McDonald, R., Method for Locating Subterranean Formations, U.S. Patent $4,413,931$ ( (to Univar Corp.) (Nov. 1983).

Phillips, W.M., Reglonal Gravity Survey of the Cascade Mountain Range, Washington, Progress Report, Department of Natural Resources, 0lympia, WA, NTIS, DOE/ET/27014-T6 (Aug- 1983).

Ibid. Preliminary Interpretation of Regional Gravity Information from the Southern Cascade Mountains of Washington.

Proffett, Jr., M.M. and J.N. Dilles, "Geologic Map of the Yerington District, Nevada," NBMG Map 77, Nevada Bureau of Mines, University of Nevada, Reno, NV 89557-0088 (Apr 11 1984).

Rouse, G.E., Sulfur Gas Geochemical Detection of Hydrothermal Systems, Final Report, NTIS, PC A03/MF A01; GPO DE 84009369 (1984).

Solhau, R.D., et al., Development and Use of A High Temperature Downhole Flowmeter for Geothermal Well Logging, Lawrence Berkeley Laboratory, NTIS, LBL-16672, GPO DE 84008253 (Dec. 1983).

"The Role of Heat in the Development of Energy and Mineral Resources in the Northern Basin and Range Province," Geothermal Resources Council, Davis, California 95617 (March 1984).

Thompson, T.W., et al., Effect of Pore Pressure on the Elastic Module, Porosity, and Permeability of Berea Sandstone and Leuders Limestone, Texas University College of Engineering, NTIS, DOE/ET/28462-1, GPO DE 83007019 (Feb. 1983).

Wilson, H.C., Formation Fluid Testing and Sampling Apparatus, U.S. Patent 4,416,152 (to Dresser Industries, Inc.) (Nov. 1983).

\section{DIRECT ENERGY UTILIZATION}

Hewlett, E.M., et al., Commercial Production of Ethanol in the San Luis Valley, Colorado, Final Report, WESTEC Services, Inc., San Diego, NTIS, DOE/ID/12193-3; GPO DE 84002425 (Ju1y 1983).

Howard, S.M., Direct Ut1lization of Geothermal Energy in Western South Dakota Agribusiness, Final Report, South Dakota School of Mines and Technology Department of Metallurgical Engineering, NTIS, DOE/ET/28419-7, GPO DE 84005320 (Sept. 1983). 
Lienau, P.J., Final Administrative Report for Technology Transfer and Information D1ssemination, January 1, 1982 - March 31, 1983, Oregon Institute of Technology, NTIS, DOE/ET/27256-T83, GPO DE 84001855 (1983).

\section{GEOTHERMAL POWER PLANTS}

Aplenc, A.M.R., Thermosyphon Boller for a Geothermal Pumping System, U.S. Patent $4,407,126$ (to Sperry Corp.) (Oct. 1983).

Auerbach, M.H., et al., "A Calcium Carbonate Scale Inhibitor for DirectContact Binary Geothermal Service," Pfizer Central Research, Journal of Petroleum Technology, 35' No. 9 (Aug 1983).

Bleim, C.J., Preliminary Performance Estimates and Value Analyses for Binary Geothermal Power Plants Using Ammonia-Water Mixture as Working Fluids, EG\&G Idaho, NTIS, EGG-GTH-6477, GPO DE 84006124 (Dec. 1983).

Bliem, C.J., and L.F. Walrath, Raft River Binary-Cycle Geothermal Power Plant, Final Report, EG\&G Idaho, EGG-2208 (April 1983).

Brown, K.A., Empirical Modeling of a Lysholm Hellcal Screw Expander, California University College of Engineering, NTIS, DOE/ET/27252-T8, GPO DE 84013695 (1984).

Dunbar, M.K., Altering the Volumetrics Expansion Ratio of a Lysholm Helical Screw Expander, California University College of Englneering, NTIS, DOE/ET/ 27252-T3 (1984).

E111s, II P.F., Review of Shell and Tube Heat Exchanger Fouling and Corrosion in Geothermal Power Plant Service, Radian Corp., Austin, TX, NTIS, DOE/SF/11503-2; GPO DE 84004539 (Dec: 1983).

Harvey, C., Sperry Low Temperature Geothermal Conversion System, Phase I and Phase II, Volume IV, Field Activitles, Final Report, Sperry Research Center, Sudbury, MA, NTIS, DOE/ET/27125-T2-Vo1. 4, GPO DE 84008041 (1984).

IbId. Volume $V$, Component Development, NTIS, DOE/ET/27125-T2-VO1, 5, GPO DE 84008040 (1984).

Proceedings, Intersociety Energy Conversion Engineering Conference, Orlando, FL (Aug. 1983).

\section{GEOTHERMAL PILOT PLANTS}

Cassel, Thomas, A.V., et al., editors, "An Analysis of Cost Performance Trade-Offs and the Heber Binary-Cycle Demonstration Project," National Technical Information Service, 5285 Port Royal Road, Springfield, VA 22161 (Feb. 1984).

Grose, T.L.T., "Th1rty-two Geologic Cross Sections, Clark, Esmeralda, Lincoln and Nye Counties, Nevada, and Ad jacent Areas in California," NBMG Open File Report 83-13, Nevada Bureau of Mines, University of Nevada, Reno, NV 89557-0088 (April 1984). 
Jernigan, R.T., Purifying Geothermal Steam, U.S. Patent 4,414,817 (to Dow Chemical Co.) (Nov. 1983).

Lippmann, M.J., and G.S. Bodvarsson, Generating Capacity of the Heber Geothermal Field, California, Lawrence Berkeley Laboratory, GPO DE 84006883 (Dec. 1983).

Matthews, H.B., Sperry Low Temperature Geothermal Conversion System, Phase I and Phase II, Final Report, Volume III, Systems Description, Sperry Research Center, Sudbury, MA, NTIS, DOE/ET/27125-T2-VO1.3, GPO DE 84008042 (1984).

1984 Nevada Bureau of Mines and Geology Publications List, Nevada Bureau of Mines, University of Nevada, Reno, NV, 89557-0088 (Apr11 1984).

Orlander, R., et al., Final Phase Testing and Evaluation of the $500 \mathrm{~kW}$ Direct Contact P1lot Plant at East Mesa, Barber-Nichols Englneering, Arvada, CO, NTIS, DOE/SF/11700-T1, GPO 84004781 (Dec. 1983).

Public Service Co. of New Mexico, Baca Geothermal Demonstration Project: PNM's Overview of Project Objectives, Plant Design, Project Completion Status, Maintenance, Storage, and Marketing of Equipment, Site Restoration, and Project Benef1ts, NTIS, DOE/ET/27163-T4, GPO DE 84007769 (Apr11 1983).

\section{TECHNOLOGY TRANSFER PROCESS}

Denny, J.E., Cooperative R\&D: DOE's Patent Policy Need Not be a Barrier, Research Management (Sept./Oct. 1983).

Stomberg, R.P., Technology Transfer at Sandla National Laboratories: First Annual Report, SAND83-0345, UC-13, Sandia National Laboratories, Albuquerque, NM (March 1983).

A Synthesis of Technology Transfer Methodologles, Proceedings, U.S. Department of Energy Technology Transfer Workshop (May 30 - June 1, 1984).

Traeger, R.K., and V.L. Dugan, Geoenergy Research and Development: Technology Transfer Update, SAND83-0018, UC-13, Sandia National Laboratories, Al buque rque, NM (Jan. 1983).

Whitaker, R., "EPRI Test Centers: Full-Scale Experience for New Technologies," EPRI Journal (Jan./Feb. 1984). 
DOE HEADQUARTERS

Geothermal Technology Division

$$
\begin{aligned}
& \text { U.S. Department of Energy } \\
& \text { CE } 324 \text { Room } 5 F 067 \\
& 1000 \text { Independence Ave., S.W. } \\
& \text { Washington, D.C. } 20585 \\
& \text { Phone (202) 252- (ext.) } \\
& \text { FTS 252-(ext.) }
\end{aligned}
$$

Robert San Martin

9275

Ronald Loose

John E. Mock

5340

James C. Bresee

Morris Ska1ka

Ralph E. Burr

4952

Gladys Hooper

4153

Raymond J. LaSala

8077

8070

Vacancy

(David Lombard acting)

Lew W. Pratsch

5778

2712

8017

Marshall Reed

8082
Deputy Assistant Secretary for Conservation and Renewable Energy

Acting Director, Office of Renewable Technology

Director, Geothermal Technology Division

Team Leader, Geosclence Programs

Team Leader, Energy Conversion Programs

Manager, Geothermal Loan Guaranty Program, Technology Transfer

Manager, Brine Chemistry, Instrumentation

Manager, Heat Cycle Research, Two-Phase Flow, Materials, Geothermal Test Facility

Manager, Geopressured Resources

Manager, Heber Binary Plant, Heber R\&D, Honey Lake Hybrid Plant, Low Enthalpy Systems

Manager, Hot Dry Rock

Manager, Hydrothermal Reservoir Research, Brine Injection Technology, Magma Energy Extraction

USGS LIaison, Salton Sea Scientific Drilling Project 
DOE FIELD OFFICES (WITH GEOTHERMAL PROGRAMS)

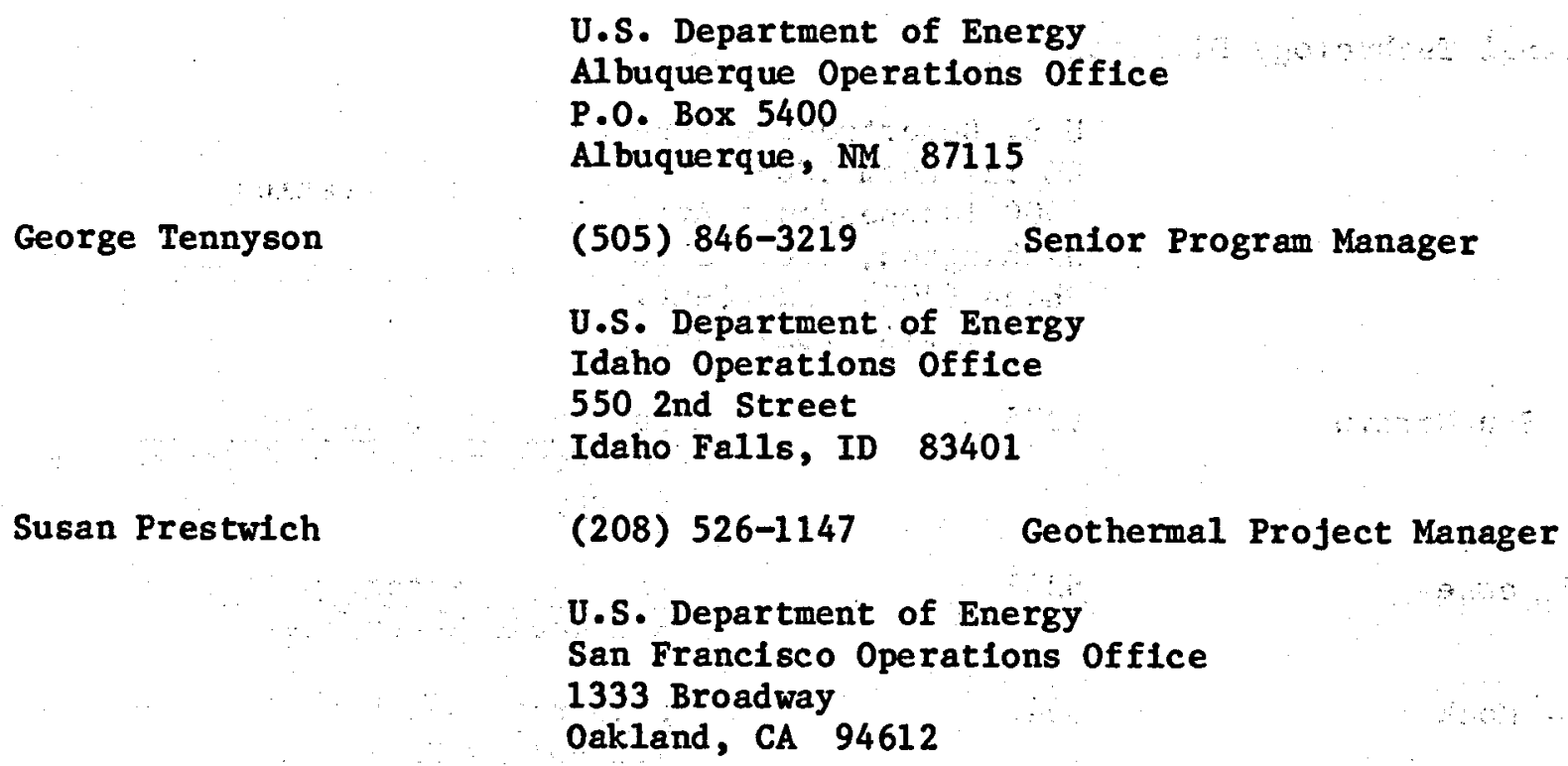

Anthony Adduci

(415) 273-7943

Chlef, Fossil and Geothermal Branch

\section{NATIONAL LABORATORIES (GEOTHERMAL RESEARCH)}

Larry Kukacka

Marcelo Lippman

John Whetten

Don Shannon
Brookhaven National Laboratory

Upton, NY 11973

(516) 282-3065 Advanced Materials Development

University of California

Lawrence Berkeley Laboratory

Berkeley, CA 94720

(415) 486-5035 Reservolr Research

University of California

Los Alamos National Laboratory

P.0. Box 1663

Los Alamos, NM 87545

(505) 667-6722 Hot Dry Rock Research

Pacific Northwest Laboratory

Battelle Blvd.

P.0. Box 999

Richland, WA 99352

(509) 376-3139 
i $-$

James Kelsey

James Dunn

Jack Ramsthaler

Jud Whitbeck
U.S. Department of Energy

Sandia National Laboratory

P.0. Box 5800

Albuquerque, NM 87185

(505) 844-6968

Geothermal Drilling Organization Hard Rock Penetration

(505) $844-4715$

Permeability Enhancement Magma Resources

Idaho National Engineering Laboratory

P.0. Box 1625

Idaho Falls, ID 83415

(208) 526-1458 Geopressured Resources

(208) 528-1879 Energy Conversion 


\section{STATE INDUSTRIAL TEAMS}

Pat Woodell

Alaska Division of Energy, Department of Commerce

3601 " C" Street

Sulte 723

Anchorage, AK 99503

(907) $562-2728$

Frank Mancin1

Arizona Solar Energy Commission $1700 \mathrm{~W}$. Washington

Phoenix, AZ 85007

(602) 255-3682

Ralph Chandler

California Energy Commission

111 Howe Avenue

Sacramento, CA 95825

(916) 324-3506

Dale Andert

Office of Energy Conservation

112 E. 14th Street

Denver, Co 80203

(303) 866-2507

Takesh1 Yosh1hara

Thomas 0'Brien

State of Hawaii Energy Division

335 Merchant St., Room 110

Honolulu, HI 96813

(808) $548-4150$

Jeff Birkby

Montana Department of Natural

Resources and Conservation

32 South Ewing

Helena, MT 59601

(406) 444-6694

Chris Wentz

New Mexico Energy and

Minerals Department

P.0. Box 2770

Santa Fe, NM 87501

(505) $827-5994$
Mike Mahlum

North Dakota Energy Office

Geothermal Program

State Capitol Building

Bismark, ND 58505

(701) 224-2290

Alex Sifford

Oregon Department of Energy Labor and Industries Building

Room 102

Salem, OR 97310

(503) $378-2778$

Steve Wegman

Office of Energy Policy

Capital Lake Plaza

Plerre, SD 51501

(605) $773-3603$

Ward Wagstaff

Utah Department of Natural Resources

Division of Water Rights

1636 West North Temple

Salt Lake C1ty, UT 84116

(801) 533-6071

Gordon Bloomquist

Washington State Energy Office $400 \mathrm{E}$. Union Street

Olympia, WA 98504

(206) 754-0774 
PRINCIPAL CONTACTS

STATE

NAME

PHONE NUMBER

ALASKA

Roman Motyka

(907) $465-3400$

Department of Natural Resources

Division of Geological and

Geophysical Surveys

3001 Porcupine Drive

Anchorage, Alaska 99501

Eugene Wescott and Don Turner

Un1versity of Alaska

(907) 474-7576

474-7198

Geophysical Inst1tute

Falrbanks, Alaska 99701

CALIFORNIA

Forrest Bacon

California Division of Mines

and Geology

2815 0. Street

Sacramento, California 95816

IDAHO

Leah Street

Idaho Department of Water Resources

Twin Falls, Idaho 83720

MONTANA

Chuck Wideman and B111 S111

Eydrotherma1 Division

(406) 496-4209

Montana College of Mineral 496-4211

Sclence and Technology

Butte, Montana 59701

NEVADA

Dennis Trexler

Division of Earth Science

(916) 445-1825

255 Bell Street, Sulte 200

Reno, Nevada 89503

NEW MEXICO

Larry Icerman

(505) $827-5886$

New Mexico Energy Research and

Development Institute

1220 South St. Francls Drive

Room 358, Pinon Bullding

Santa Fe, NM 87501

OKLAHOMA

W1lliam Harrison

(405) $325-3032$

Ken Lusa

Oklahoma Geological Survey

University of Oklahoma

Room 163

Norman, Oklahoma 77019 
OREGON

George Priest

Oregon Department of Geology and Mineral Industries

1005 State Office Building

Portland, Oregon 97201

UTAH

Don Mabey

(801) $581-6831$

Utah Geological and Mineral Survey

606 Blackhawk Way

Salt Lake City, Utah 84108

WASHINGTON

Eric Schuster

Department of Natural Resources

(206) $459-6372$

Division of Geology and Earth

Resources

Mail Stop PY12

Olympia, Washington 98504 